Portland State University

PDXScholar

$9-1-2020$

\title{
Understanding Evangelical Support for, and Opposition to Donald Trump in the 2016 Presidential Election
}

Joseph Thomas Zichterman

Portland State University

Follow this and additional works at: https://pdxscholar.library.pdx.edu/open_access_etds

Part of the Political Science Commons

Let us know how access to this document benefits you.

\section{Recommended Citation}

Zichterman, Joseph Thomas, "Understanding Evangelical Support for, and Opposition to Donald Trump in the 2016 Presidential Election" (2020). Dissertations and Theses. Paper 5570.

https://doi.org/10.15760/etd.7444

This Thesis is brought to you for free and open access. It has been accepted for inclusion in Dissertations and Theses by an authorized administrator of PDXScholar. Please contact us if we can make this document more accessible: pdxscholar@pdx.edu. 


\title{
Understanding Evangelical Support for, and Opposition to
}

Donald Trump in the 2016 Presidential Election

$$
\text { by }
$$

Joseph Thomas Zichterman

A thesis submitted in partial fulfillment of the requirements for the degree of

\author{
Master of Arts \\ in \\ Political Science
}

Thesis Committee:

Richard Clucas, Chair

Jack Miller

Kim Williams

Portland State University

2020 
Abstract

This thesis addressed the conundrum that 81 percent of evangelicals supported Donald Trump in the 2016 presidential election, despite the fact that his character and comportment commonly did not exemplify the values and ideals that they professed. This was particularly perplexing to many outside (and within) evangelical circles, because as leaders of America's "Moral Majority" for almost four decades, prior to Trump's campaign, evangelicals had insisted that only candidates who set a high standard for personal integrity and civic decency, were qualified to serve as president.

In order to deal with this problem, I conducted a qualitative study, which followed the ensuing procedures. First, I conducted a general review of the history of evangelical participation in American politics (discussed in chapter two). Second, I conducted a general review of public statements made (in video, audio, and written formats) by prominent evangelical leaders, who supported Trump's 2016 presidential run (discussed in chapter three). Third, I conducted a general review of public statements made (in video, audio, and written formats) by prominent evangelical leaders, who opposed Trump's 2016 presidential run (discussed in chapter four). And finally, I compared and contrasted the arguments that both groups of evangelical leaders made (discussed in chapter five), to enable the reader to understand (and perhaps empathize with) the full nuance of perspectives that existed within the broader evangelical movement. Although I focused preeminently on the works of self-identifying evangelicals, I also consulted a significant sampling of relevant supplemental works by non-evangelical writers, which provided insightful historical, sociology and psychological analysis. 
I uncovered the following research findings in his study. The three key categories of arguments made by evangelicals who supported Trump pertained to evangelical theology (which undergirds their belief system); evangelical access (which Trump provided them within his administration); and evangelical policies (which Trump promised to champion). And the three key categories of arguments made by evangelicals who opposed Trump pertained to the conflation of the gospel with politics; Trump's deficient moral leadership; and Trump's threat to social justice.

In the final analysis, I concluded that evangelicals who supported Trump emphasized the preeminent importance of his policy agenda, which when enacted, would enable them to live out their faith authentically, proclaim the gospel freely and revive Christian nationalism, to secure God's protection and prosperity for the nation. And the six key policies that these evangelicals prioritized were the nomination of conservative judges; the protection of religious liberty; the promotion of Israel's welfare; the advancement of the pro-life agenda; the effective enforcement of immigration law; and the perpetuation of Republican, fiscal conservativism.

Conversely, evangelicals who opposed Trump emphasized the preeminent importance of believers committing to lend their credibility, only to presidential candidates who upheld a high standard of moral decency and civility, so the gospel was disassociated from the pursuit of state power and resources and social justice for the most vulnerable members of society was maintained. Even if it meant that Hillary Clinton won the presidency and pursued a left-wing policy agenda that ran cross-grain to their values, these evangelicals determined to follow the dictates of their consciences and trust God with the results. 
Future researchers may wish to evaluate whether the respective percentages of evangelicals who support and oppose Trump shift substantially, in the run-up to the next election, based on the president's job performance during his first term. And these researchers may also wish to observe, in what ways (if any) evangelical leaders who support and oppose Trump respectively, modify their arguments throughout his 2020 presidential campaign. 
Table of Contents

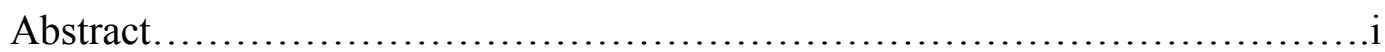

Chapter One

Introduction................................................................

Chapter Two

Historical Background...................................................22

Chapter Three

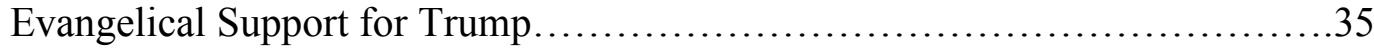

Chapter Four

Evangelical Opposition to Trump........................................... 75

Chapter Five

Conclusion.............................................................93

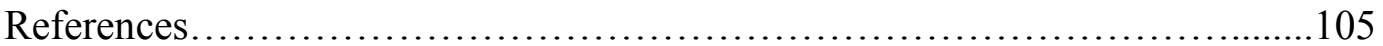




\section{CHAPTER ONE}

\section{INTRODUCTION}

Evangelical Christians make up about 25 percent of the total U.S. population, ${ }^{1} 26$ percent of voters in presidential elections, ${ }^{2}$ and 33 percent of Republican primary voters. ${ }^{3}$ Approximately 81 percent of white evangelicals supported Donald Trump in the 2016 general election, while 67 percent of black evangelicals (who comprise 19 percent of the entire evangelical community) voted for Hillary Clinton. ${ }^{4}$ Perhaps most surprisingly, 40 percent of white evangelicals supported Trump in the GOP primaries, ${ }^{5}$ despite the fact that there were other viable candidates, who were outspoken evangelicals, including Ted Cruz (the son of a conservative, southern Baptist evangelist) and Mike Huckabee (an ordained Baptist minister).

\footnotetext{
${ }^{1}$ N.A. "Religious Landscape Study,” Pew Research Center. N.D. https://www.pewforum.org/religiouslandscape-study (accessed February 13, 2020).

2 Jessica Martinez and Gregory Smith, "How the Faithful Voted: A Preliminary 2016 Analysis," Pew Research Center. November 19, 2016. https://www.pewresearch.org/fact-tank/2016/11/09/how-the-faithfulvoted-a-preliminary-2016-analysis/ (accessed March 10, 2020).

${ }^{3}$ The Arizona Center for Judaic Studies, "Religion and the 2016 Election: Historical Context and Unusual Alliances - Prof. Randall Balmer," March 31, 2019, video, 36:36, https://www.youtube.com/watch?v=PjMhdHHkDT0

4 Tara Isabella Burton, "White Evangelicals Are The Only Religious Group To Support Trump," Vox. October 3, 2018. https://www.vox.com/identities/2018/10/3/17929696/white-evangelicals-prri-poll-trumppresidency-support (accessed February 13, 2020).

${ }^{5}$ Rebecca Barrett-Fox, “King Cyrus President: How Donald Trump's Presidency Reasserts Conservative Christians' Right to Hegemony," Humanity and Society 42:4 (2018): 503.
} 


\section{The Conundrum}

As a group, evangelicals drew considerable criticism for backing Trump,

primarily because his character and comportment, in so many ways, appeared to be out of sync with their professed values. This anomaly seemed especially mystifying to many, because when Democratic president, Bill Clinton, was mired in scandal (involving openly avowed deceit and sexual promiscuity), a legion of evangelical leaders called for his resignation. In 1998, dozens of their most influential luminaries signed the "Declaration Concerning Religion, Ethics, and the Crisis of the Clinton Presidency," which asserted that "certain moral qualities [were] central to the survival of our political system, among which [were] truthfulness [and] integrity," and that there was "a reasonable threshold of behavior beneath which our public leaders should not fall." ${ }^{\prime 6}$ So, since Donald Trump's entire adult life had been suffused with conspicuous, brazen moral flaws, outsiders were baffled by the robust evangelical endorsement that his 2016 presidential candidacy received.

This enigma can perhaps best be exhibited by a 1998 support letter, authored by James Dobson (founder of the evangelical ministry, "Focus on the Family"), to address then president, Bill Clinton's, recent improprieties. Dobson wrote,

Because the economy is strong, millions of people have said infidelity in the Oval Office is just a private affair--something between himself and Hillary. We heard it time and again during those months: 'As long as Mr. Clinton is doing a good job, it's nobody's business what he does with his personal life ....' That disregard for morality is profoundly disturbing to me ... . Obviously, [his supporters] are motivated not by the welfare of women but by raw political power . . . . There was plenty of evidence during the first Presidential election that Bill Clinton had a

${ }^{6}$ The Presbyterian Lay Committee, "Declaration Concerning Religion, Ethics, and the Crisis in the Clinton Presidency,” The Presbyterian Lay Committee. November 16, 1998. https://layman.org/news86fd/ (accessed February 22, 2020). 
moral problem. His affair with Gennifer Flowers, which he now admits to having lied about, was rationalized by the American people .... There were other indications that Bill Clinton was untruthful and immoral. Why, then, did the American people ignore so many red flags? ${ }^{7}$

Dobson's letter went on to reprove those who pragmatically rationalized that, after all, they were electing "political" leaders, not "clergy," who sometimes paradoxically, had to be "brutal" when championing noble causes. Moreover, he noted that numerous accusations of wrongdoing had been levied against a surfeit of Clinton's close associates and several, in fact, were already behind bars. Dobson declared,

As it turns out, character DOES matter. You can't run a family, let alone a country, without it. How foolish to believe that a person who lacks honesty and moral integrity is qualified to lead a nation and the world! Nevertheless, our people continue to say that the President is doing a good job even if they don't respect him personally. Those two positions are fundamentally incompatible. ${ }^{8}$

In light of all this, it was particularly perplexing to many when in 2016, Dobson not only endorsed Trump's presidential campaign, but agreed to serve on his "Faith Advisory Council" as well. Dobson maintained that though he did not, in any way, condone the GOP candidate's quondam lifestyle, he was “more concerned about America's future than Donald Trump's past."

Most evangelicals appeared to agree. In October of 2016, a Public Religion Research Institute poll found that 72 percent of white evangelicals believed that "an elected official [could] behave ethically even if they [had] committed transgressions in

\footnotetext{
7 James Dobson, “Support Letter," Ontology. September, 1998. Accessed on February 22, 2020, http://ontology.buffalo.edu/smith/clinton/character.html (accessed February 22, 2020).

${ }^{8}$ Ibid.

9 James Dobson. "Dr. James Dobson: How Christians Can Support Donald Trump but Condemn Bill Clinton," Charisma News. October, 2016. http:/www.charismanews.com/politics/opinion/60502-dr-jamesdobson-how-christians-can-support-donald-trump-but-condemn-bill-clinton (accessed February 28, 2020).
} 
their personal life - a 42-point jump from 2011, when only 30 percent of white evangelical Protestants said the same."10 This drastic about-face by the faithful, left onlookers scratching their heads in disbelief and disdain for their ostensible hypocrisy.

Though partisanship has become a defining characteristic of contemporary politics, especially during elections, it continues to be essential to understand the fundamental dynamics at work within the evangelical Christian movement, due to their unique role in the nation's political processes. And the primary purpose of this thesis is to fully unpack this conundrum by elucidating the rationale of evangelicals who supported Donald Trump, as well as those who opposed him, during the 2016 presidential election.

\section{Review of Literature}

There are two bodies of literature to which this study is relevant. The first focuses on the political science literature pertaining to the relevance of religion in shaping modern American politics (particularly as it impacted voting). The second focuses on the forces that shape how Americans vote. This section begins by looking at four primary ways that religion has been relevant in politics: the implementation of key principles that ideally guide religion's shaping of American politics; religion's impact on Republican and Democratic Party politics; the combined impact of religion and intersectionality on American politics; and the impact of non-Christian religious groups on American politics.

\footnotetext{
${ }^{10}$ PRRI, “Backing Trump, White Evangelicals Flip Flop on Importance of Candidate Character," PRRI. October 19, 2016. https://www.prri.org/research/prri-brookings-oct-19-poll-politics-election-clintondouble-digit-lead-trump (accessed February 28, 2020).
} 
And this section concludes by briefly discussing what scholars know about forces that shape how Americans vote.

Key Principles that Ideally Guide Religion's Shaping of American Politics

Martin Medhurst (professor of political science at Baylor University) posited three key principles that ideally guide religion's shaping of American politics. First, politicians should treat all American citizens justly and equally, regardless of their religious affiliation. ${ }^{11}$ John Carr (director of Georgetown University's Initiative on Catholic Social Thought \& Public Life") affirmed that "believers have the same rightsno more, no less than-other citizens."12

Second, politicians should not promulgate teaching that was specific to one religion, over the teaching of other faith-traditions. ${ }^{13}$ E. J. Dionne (professor of government at Georgetown University and Senior Fellow in Governance and Studies at the Brookings Institute), avouched that in a "pluralistic country, you may come to your conclusions because of religious convictions, but you have to make your case in a democratic-republic to people, whether they share your convictions or not. ${ }^{14}$

\footnotetext{
${ }^{11}$ Martin J. Medhurst, 'Mitt Romney, 'Faith in America,' and the Dance of Religion and Politics in American Culture," Rhetoric \& Public Affairs 12:2 (2009): 202.

12 Bjorn Ottosson, "Religious Voters Impact on Midterm Elections Georgetown Panel," Filmed [November 2018], YouTube video, 147:52. Posted [November 2018], https://www.youtube.com/watch?v=ivlq7FHIK74

${ }^{13}$ Martin J. Medhurst, “Mitt Romney,” 202.

14 Brookings Institution, "The Role of Religion in American Politics," Filmed [October 2010], YouTube video, 7:16, Posted (October 2010], https:/www.youtube.com/watch?v=pRGLIY44qHg
} 
Third, voters should recognize that a politician's faith would inexorably affect how he or she governed. ${ }^{15}$ And John Carr maintained that "when people bring their deepest convictions to [bear in resolving difficult] questions, ... [they] enrich political life. Because when you're not talking about fundamental values, then it can only be about power, money and ego." ${ }^{" 16}$ Michael Corbett (professor of political science at Ball State University), added that,

the points at which politics and religion overlap often concern those things upon which people place the greatest value .... Religion provides ways that people can live their lives in conscious relationship with principles of ultimate importance ... . [And] politics provides a vehicle - perhaps the primary vehicle--by which people can work to give force to their conceptions of what is right and just [for Americans], ... whose politics can be informed by faith without being dominated by it. ${ }^{17}$

In addition, Kenneth Wald (professor of political science at the University of Florida) noted that the primary question used to be, "what's the effect of religion on politics?" However, now the key question was, "what's the effect of politics on religion?" 18 E. J. Dionne explained that this was often because "the compromises that are absolutely necessary [in the political process], . . can be very challenging to a person of deep faith." 19

\footnotetext{
${ }^{15}$ Martin J. Medhurst, “Mitt Romney,” 204.

${ }^{16}$ Bjorn Ottosson, "Religious Voters."

${ }^{17}$ Michael Corbett, Julia Corbett-Hemeyer and Matthew J. Wilson, Politics and Religion in the United States, New York: Routledge Publishing, 2014: 332, 336.

${ }^{18}$ IRCPL, "Religion and the Elections," Filmed [October 2016], YouTube video, 1:44:09, Posted [October 2016], https://www.youtube.com/watch?v=0dPC3GVPNio

19 JFK Library, "Religion and Politics in America," Filmed [November 2018], YouTube video, 132:40, Posted [November 2018], https:/www.youtube.com/watch?v=gzHais2xWnc
} 


\section{Religion's Impact on Republican and Democratic Party Politics}

John Carr claimed that "when people talk about religious voters" they were typically referring to "white evangelicals and white Catholics." ${ }^{20}$ However, religion's impact on both Republican and Democratic Party politics had been substantial.

John Ayers (political scientist and Vice Chief of Innovation at San Diego State University) asserted that "religiously devout voters" typically identified as Republican, "while secular or nominal religious adherents tend[ed] to be Democratic."21 And Penny Edgell (professor of sociology at the University of Minnesota), stated that Republican constituencies all "share[d] a preference for cultural Christianity, understanding Christian traditions as grounding . . . civic life and fostering national identity."22

In respect to evangelicals specifically, Gerardo Marti (chairmen of the sociology department at Davidson College), declared that evangelicals had "given up on spiritual revival as a means of change .... Their goal [was] no longer to morally persuade the public of their religious convictions ... [but] to authoritatively enforce behavioral guidelines through elected and nonelected officials .... They view[ed] themselves as a shrinking group that needs the protection of the State."23

\footnotetext{
${ }^{20}$ Bjorn Ottosson, "Religious Voters."

${ }^{21}$ John W. Ayers, "Changing Sides: 9/11 and the American Muslim Voter," San Diego State University Review of Religious Research 49:2 (December, 2007): 189.

${ }^{22}$ Penny Edgell, “An Agenda for Research on American Religion in Light of the 2016 Election,” Sociology of Religion 78:1 (2017): 2.

${ }^{23}$ Gerardo Marti, "The Unexpected Orthodoxy of Donald J. Trump: White Evangelical Support for the $45^{\text {th }}$ President of the United States," Sociology of Religion: A Quarterly Review 80:1 (2019): 6.
} 
And Gregory Smith (Associate Director of Research at the Pew Research Center), recorded that in recent elections, the Catholic vote tended to be equally distributed between the Republican and Democratic parties. ${ }^{24}$ E. J. Dionne elucidated that "if you look at the church's agenda on social welfare, on health care, on poverty, on the death penalty, on immigrants and on war and peace, you would say, this is a liberal church. [But] if you look at the church's teaching on abortion, contraception [and] gay marriage, you'd say, this is a conservative church." 25

Historically speaking, religion had also been a critical impetus for re-shaping Democratic politics during the labor and civil rights movements, which enjoyed broad support from the Christian and Jewish communities. However, over the past four decades, Kenneth Wald identified the Democratic religious voting coalition as consisting chiefly of Jews, Muslims, non-white Catholics, and Mormons, who all had "histories of state-sponsored discrimination .... [And more recently,] the rhetoric at the top of the Republican ticket has really activated those concerns. ${ }^{26}$ Moreover, Robert P. Jones (head of the Public Religion Research Institute) specifically fingered "white Christian voters" as embodying the "enemy" cultural forces against which Democrats were contending. ${ }^{27}$

\footnotetext{
${ }^{24}$ Bjorn Ottosson, "Religious Voters.”

${ }^{25}$ JFK Library, "Religion and Politics."

${ }^{26}$ IRCPL, "Religion and the Elections."

${ }^{27}$ Harvard Divinity School, "The End of White Christian America: A Conversation with E. J. Dionne and Robert P. Jones,” Filmed [February 2018], YouTube video, 144:49, Posted [February 2018], https:/www.youtube.com/watch?v=gRqTYX6IwAY
} 
In addition, the Democratic party had attracted a large constituency called the "nones," ${ }^{28}$ who self-identified as "religious" or "spiritual," but claimed no official faithaffiliation, largely because they deemed religion to be anti-scientific and linked with the Republican Party. ${ }^{29}$ According to Sarah Posner (a distinguished political journalist and author), the profuse diversity within the Democratic Party, engendered a "schizophrenic . . faith outreach," with multiple religious groups desiring prominence, while many of the “nones' preferred that religion be expunged from the political discourse entirely. ${ }^{30}$ Anthea Butler (professor of religious studies at the University of Pennsylvania) proclaimed that "the reason why people care about [religion] is because they've been trained to care about it ... since Reagan." However, as time continued to pass, she predicted that there would be substantially less interest in "God-talk" in American politics. ${ }^{31}$ And Kenneth Wald astutely observed that religion was "less exuberant" on the religious left, because of its adherents" "appreciation for the nature of the United States as a republic." These individuals had "decoupled religion from citizenship" and therefore, often did not make decisions primarily "based on their [personal] values in the public sphere." ${ }^{32}$

To sum up, George Marsden (eminent American religious historian) concluded that "both party coalitions welcome minority blocs with explicit religious visions ....

\footnotetext{
${ }^{28}$ Michael Corbett, Politics and Religion, " 232.

${ }^{29}$ JFK Library, "Religion and Politics.”

${ }^{30}$ IRCPL, "Religion and the Elections."

${ }^{31}$ Ibid.

${ }^{32}$ Ibid.
} 
[However,] both demand in return that these visions be compromised in support of essentially secular, larger political agendas." ${ }^{, 33}$

The Combined Impact of Religion and Intersectionality on American Politics

To cognize how religion shaped American politics, one must also consider its combined impact with intersectionality factors. Penny Edgell pointed out that only "white" evangelicals and Catholics voted for Trump in appreciable numbers. Therefore, one had to repudiate "insider narratives that focus on religious belief as a primary causal mechanism, that has a unitary and straightforward effect on political action, policy preferences, and social attitudes." One must also factor in "race, gender, sexuality [and] social class, ... [which] constitute people's understandings of their identities and interests." ${ }^{34}$ And George Marsden specifically pinpointed "religion ... combined with ethnicity" as "the best predictor of political behavior throughout most of the history of the United States." 35

Here was a case in point: E. J. Dionne claimed that in the 2016 election, white Christians had voted "more like older, white southerners than ... like Christians ... [hearkening] back to the Goldwater campaign, where many of their parents and grandparents shifted from the Democratic to the Republican Party, in reaction to civil

\footnotetext{
${ }^{33}$ Mark A. Noll and Luke E. Harlow, eds. Religion and American Politics: From the Colonial Period to the Present. New York: Oxford University Press, 2007: 468. ProQuest Ebook Central, https://ebookcentralproquest-com.proxy.lib.pdx.edu/lib/psu/detail.action?docID $=415713$.

${ }^{34}$ Penny Edgell, “An Agenda for Research,” 1.

${ }^{35}$ Mark A. Noll, Religion and American Politics,” 459.
} 
rights action. ${ }^{36}$ Nina Burleigh (best-selling political author) also highlighted that the percentage of white, Christian voters had been declining rapidly over the past several decades: from seventy-three percent in $1992,{ }^{37}$ to fifty-four percent in 2008 , and all the way down to forty-three percent in $2016 .^{38}$

Leslie Callahan (a journalist for the Black Christian News Network) wrote that the black church had a long-standing tradition of "resistance," which its members needed to enact, in order to re-shape American politics. And she "questioned ... whether any redeeming value could be found in the American Christian experiment," warning her readers to guard against "incorporating theological and social analyses that white evangelicals market to black churches," which were "pioneered with oppression in mind." 39

In respect to immigrant religious groups, Prema Kurien (professor of sociology at Syracuse University) observed that it typically took "a generation or two" for them to "enter into the political mainstream of their new homelands" and affect notable change. ${ }^{40}$ Their chief challenge was to unite and form a distinct organization that would be

\footnotetext{
36 JFK Library, "Religion and Politics."

${ }^{37}$ Nina Burleigh, "Evangelical Christians Helped Elect Donald Trump, but Their Time as a Major Political Force Is Coming to an End; Republicans Relied on Evangelicals for Decades, but a Political Reckoning is Afoot." Newsweek. December 21, 2018. https:/www.newsweek.com/2018/12/21/evangelicals-republicanstrump-millenials-1255745.html (accessed March 25, 2020).

${ }^{38}$ IRCPL, "Religion and the Elections."

${ }^{39}$ Leslie D. Callahan, “The Black Church in Trump's America: Refuge and Resistance,” Mississippi Link 23:6 (December 1, 2016): 10 .

${ }^{40}$ Prema Kurien, "Who Speaks for Indian Americans? Religion, Ethnicity, and Political Formation," American Quarterly 59:3 (September 2007): 760.
} 
"recognized as [their] authentic [voice] . . by U.S. policymakers." ${ }^{41}$ And Kurien argued that religion had proven to be "the most legitimate form of ethnic expression," because when pan-ethnic groups coalesced around it, in contradistinction to other aspects of their native culture, this was not perceived as unpatriotic by Americans. ${ }^{42}$

The Impact of Non-Christian Religious Groups on American Politics

There were three major non-Christian religious groups, which had markedly shaped American politics: Judaism (with 7 million members), Islam (with 3.5 million members) and Hinduism (with 2.8 million members). ${ }^{43}$ First, in respect to Judaism, James Besser averred that it was the Democratic Party, which initially provided Jews access to "mainstream . . society and institutions," back in the 1930 s. ${ }^{44}$ So, they essentially owed their affluence and influence to "liberals and secularists," rather than to "conservatives or Christians" (48). And though their "tradition [was] profoundly conservative, with absolute standards for behavior" (including opposition of Orthodox members to LGBT rights and feminism), "the community's [political] structure [was] liberal," and they had always existed as "little "welfare states"” (48). Overall, James Besser (a prominent Washington D.C., political journalist) noted that all minority religious groups tended to thrive most when Democrats were in office, because their party stood for more "broadly

\footnotetext{
${ }^{41}$ Ibid., 760.

${ }^{42}$ Ibid., 764.

${ }^{43}$ N.A. "Religious Landscape Study,"

${ }^{44}$ James D. Besser, "High Noon,” 48.
} 
defined civil rights, . . .equality, economic opportunity for all and tolerance." ${ }^{45}$ Indeed, Jews had pronouncedly shaped American politics, not only due to their sizeable voting bloc, but because their population was centralized in cultural hubs (like New York City), where they could strategically propagate their ideology through prominent media outlets (48).

Second, Islam was America's "fastest-growing” religion and Muslim "prayers were offered for the first time at both the Republican and Democratic presidential nomination conventions in 2000." ${ }^{46}$ However, after the events of 9-11, their community began to be perceived as "radically different from Judeo-Christian groups" and they "became a target of religious profiling." 47 At present, public opinion was more negative toward the Islamic faith than it was toward any other religious minority. And though Muslims tended to share the "traditional" values of conservatives, the overwhelming majority of them voted for Democratic candidates, due to "security" issues. ${ }^{48}$

Marwa Abed (a journalist for Islamic Horizons magazine), bemoaned that pollsters were still routinely questioning Muslims about their level of affinity for religious extremism and that their community served as "political scapegoats" to draw "right-wing" voters to the ballot box for the Republican Party. ${ }^{49}$ About 47 percent of U.S.

\footnotetext{
45 James D. Besser, "High Noon for Jewish Politics," Baltimore Jewish Times 220: 6, (December 9, 1994): 48.

${ }^{46}$ John W. Ayers, “Changing Sides,” 187-188.

${ }^{47}$ Ibid., 188.

48 Ibid., 189.

49 Marwa Abed, “Get Out the Muslim Vote.” Islamic Horizons 41 (May/June 2012): 3.
} 
citizens believed that "the values of Islam [were] at odds with American values" and their "way of life." ${ }^{50}$ And Muslims were specifically perceived as "authoritarian, antidemocratic [and] ... allied with foreign powers. ${ }^{.51}$ Consequently, Abed declared that Muslim Americans "must reclaim their voice and demand that they be accepted as equal partners in this society. A vote is a ticket to say that a person — politically and sociallymatters." 52

Third, Prema Kurien noted that Hinduism had no official "founder, ... . ecclesiastical structure of authority, or ... single canonical text or commentary," while "Hindu nationalism first emerged as a reaction to British colonialism and was explicitly codified in the 1920s. ${ }^{.53}$ And the Hindu American Foundation (HAF) was founded in 2004 to "consolidate [the] demands" and "provide a voice" for Hindus living in America, enabling their community to impact the political process (769).

After 9-11, Hindus aggressively opposed the consolidation of American culture behind Judeo-Christian faiths, due to the acute anti-Islamic sentiments of U.S. citizens, while also highlighting the stark distinctions between the two Eurasian religions (774). Since the U.S. Hindu population was quite small, they had less impact on shaping American politics at the ballot box than they did by contributing financially to sympathetic political candidates (762).

\footnotetext{
${ }^{50} \mathrm{Ibid}, 3$.

${ }^{51}$ JFK Library, "Religion and Politics in America."

${ }^{52}$ Marwa Abed, "Get Out the Muslim Vote," 3.

${ }^{53}$ Prema Kurien, "Who Speaks," 765.
} 


\section{Forces that Shape How Americans Vote}

While the main concern of this study was to understand religion in politics, its findings are also relevant to research on other forces that shape how Americans vote. And scholars noted that Americans tended to evaluate presidential candidates based on four key criteria: personal characteristics (such as "morality," "intelligence," "empathy," and "leadership" ability); "party affiliation;" "issue positions;" and in the case of an incumbent presidential candidate, the performance of the economy during the year prior to an election. ${ }^{54}$ These four factors also overlapped and were influenced by one another. For example, based on surveys conducted from 1984-2008 by the American National Election Studies (ANES), a voter's perception of an incumbent's personal characteristics could be significantly impacted by how the economy performed during the year prior to the election. ${ }^{55}$ To be more specific, when voters perceived objectively (or even subjectively) that the economy had performed poorly, in their minds, this was often a significant indicator of the incumbent president's leadership skill and compassion, even if that perception was based on "low-information rationality," such as a general or personal sense of economic prosperity or decline. This was particularly true if voters assigned blame to the incumbent for their economic decline at their state level. ${ }^{56}$

\footnotetext{
${ }^{54}$ Lisa P. Argyle, Marcus Arrajj, Skylar Covich, E.G. Garay, Julian Gottlieb, Heather E. Hodges and Eric R.A.N. Smith, "Economic Performance and Presidential Trait Evaluations: A Longitudinal Analysis," Electoral Studies, 43 (2016): 52-53.

55 Ibid., 52.

56 Ibid., 53.
} 


\section{Conclusion}

The study explicated in this thesis is both related to, and different from the review of the literature in the following important ways. First, in respect to Medhurst's three key principles that ideally guide religion's shaping of American politics, this study examined to what extent evangelicals who supported (and those who opposed) Trump, advocated for the equal treatment of all Americans, irrespective of religious affiliation; whether they pressured Trump to promote evangelical religious teachings above those of other faithtraditions; and whether they encouraged Trump to allow his professed Christian faith to affect the way that he governed.

Second, in respect to religion's impact on Republican and Democratic Party politics, this study focused almost exclusively on how evangelicals impacted the Republican Party, while omitting significant discussion regarding the influence that all other religious groups had on either party. It also sought to determine whether evangelicals sought to marshal government resources to enforce their moral code within American society and to protect themselves from their political enemies.

Third, dialogue on the combined impact of religion and intersectionality on American politics was absent from the apologetic presented by evangelicals who supported Trump, which is recorded in chapter three. However, a noteworthy portion of chapter four, which outlines the arguments of evangelicals who opposed Trump, was dedicated to concerns related to ethnic, gender, and class issues. And fourth, this study omitted discussion on the impact of non-Christian religious groups (like Judaism, Islam, and Hinduism) on American politics, other than to expound on the threat that 
evangelicals who supported Trump believed migrant adherents to those faith-traditions posed, both to Christian nationalism and to all U.S. citizens, through terrorist activities (see chapter three).

Finally, in respect to the four other forces that scholars identified as shaping voting behavior, this study did focus particularly on how evangelicals who opposed Trump evaluated his personal characteristics (such as morality, intelligence, empathy, and leadership ability). While it conversely focused on how evangelicals who supported Trump evaluated him based primarily on party affiliation and issue positions. However, neither evangelical group focused their apologetic on factors related to economic prosperity or decline, since Trump was not the incumbent during the 2016 election.

Generally speaking, this study contributed to the overall body of literature by outlining a concise history of evangelical participation in American politics, highlighting the key issues that have historically mobilized their community (in chapter two). But its most vital contribution was recorded in chapters three and four, which provided an indepth look at what evangelical groups (which either supported or opposed Trump), said themselves about the GOP candidate, and to what extent they believed that religion should shape American politics. Specifically, these chapters articulated how both groups viewed politics from a theological perspective and what their adherents believed the effect of Trump's presidency on U.S. civic life had been. And in that regard, this study helped its readers resolve the tension generated by the fact that 81 percent of evangelicals supported Trump in 2016, despite the fact that his character and comportment seemed so out of sync with their professed values. 
Partisanship and transactions are primary ways in which elections and politics are often explained. However, I am making a case that there is a different dynamic at work with evangelical Christians; namely that these voters are not just motivated by traditional partisanship and seeking of valuable goods, but by their faith as well. They have a distinct character which makes it important to understand their behavior.

\section{Research Focus and Methodology}

The initial challenge for effective research of this topic, was to accurately define the term "evangelical." Fundamentally speaking, it referred to one who embraced the "gospel" (meaning "good news") of Jesus Christ. But the consensus of scholarship seemed to point to four defining characteristics (dubbed as the "Bebbington quadrilateral"), of those who self-identify with this designation. That list which follows, is the only one officially endorsed (at least in respect to its main points) by the National Association of Evangelicals, which is arguably the movement's most notable consortium: 1) "Biblicism" (a belief in the Bible as the authoritative Word of God); 2) "crucicentrism" (a belief that salvation is received as a free gift through faith in Christ, based on His substitutionary death, which atoned for human sin); 3) "conversionism" (a personal conversion ["born again"] experience, whereby one turns from past wrongdoings and calls upon Christ for forgiveness); and 4) "activism" (a belief that one must evangelize others, inviting them also to receive Christ as the forgiver and leader of their lives).${ }^{57}$ And a standard practice for pollsters was to identify an "evangelical" voter

${ }^{57}$ David Bebbington. Evangelicalism in Modern Britain: A History from the 1730s to the 1980s (London: Unwin Hyman, 1989), 5-17. 
as someone who self-described as such, or who claimed to have had a "born-again" experience. $^{58}$

The specific focus of this thesis will be to explicate the rationale of prominent evangelicals who supported Donald Trump, as well as those who opposed him in the 2016 presidential election. It will focus on the perspectives of these evangelical leaders because they provide important cues to rank and file evangelical voters, who tend to respect their judgment.

This thesis will reflect a qualitative (rather than quantitative) study, which primarily reviewed the public statements and written works of prominent, self-professing evangelicals, to enable the reader to understand (and perhaps empathize with) the full nuance of perspectives that exists within the broader evangelical movement. Also, a significant sampling of relevant supplemental works by non-evangelical writers will be consulted, which can offer additional insights for effective historical, sociological and psychological analysis.

Chapter two will provide a concise, historical overview of evangelical participation in American politics, exploring relevant questions like, under what circumstances have evangelicals been involved historically in American politics? Who have been their movement's key leaders and what kind of political influence have they sought to exercise? What political institutions, organizations and networks have they

\footnotetext{
${ }^{58}$ Jonathan Merritt, "Defining 'Evangelical,"” The Atlantic. December 7, 2015. https://www.theatlantic.com/politics/archive/2015/12/evangelical-christian/418236/ (accessed February 13, 2020).
} 
developed? What issues have been most important to them? How have politicians sought to solicit their support? And how have evangelicals affected American politics?

Chapter three will elucidate the rationale of prominent evangelicals who supported Donald Trump in the 2016 presidential election, exploring relevant questions like, how did evangelicals who supported Trump view American politics from a theological and ethical perspective? How did Trump specifically seek to solicit their support? What was the progression of thought within evangelical circles that culminated in the overwhelming majority of them supporting Trump in 2016? And how did evangelical apologists justify their support of Trump to their critics?

Chapter four will explain the rationale of prominent evangelicals who opposed Donald Trump in the 2016 presidential election, exploring relevant questions like, how did evangelicals who opposed Trump view American politics from a theological and ethical perspective? What specific criticisms have they levied against Trump and his evangelical supporters respectively? How did they perceive his presidency to have affected both America and the evangelical movement? And what recommendations did they make to their fellow evangelicals going forward?

Chapter five will conclude this thesis, first by outlining the most substantive contributions that this study made to contemporary scholarship regarding the impact of religion in shaping American politics. And second, it will compare and contrast the key arguments of Trump's prominent evangelical supporters (discussed in chapter three) with those of his critics (discussed in chapter four). Thus, the reader will be furnished with a 
more fully nuanced perspective for understanding evangelical support for, and opposition to, Donald Trump in the 2016 presidential election. 


\section{CHAPTER TWO}

\section{HISTORICAL BACKGROUND}

The term "evangelical" was first employed in the United States, to designate those who participated in the First Great awakening (led by Jonathan Edwards in the 1700s) and the Second Great Awakening (led by Charles Finney in the 1800s). ${ }^{59}$ While Edwards' eighteenth century revival targeted middle-upper class American citizens, its nineteenth century progeny primarily impacted the more marginalized members of society. ${ }^{60}$ Consequently, Finney and his fellow noteworthy evangelists stressed, not only the gospel's power to save one's eternal soul, but its implicit impact on contemporary social justice issues like opposition to slavery; solicitation of funds to feed and educate the poor; and the protection of marketplace workers, along with women and children.

Notwithstanding, John Fea (evangelical professor of history at Messiah College), noted that these revivalists were also among the most outspoken critics of immigration, warning that an influx of outsiders (especially Catholic migrants) could steer the U.S. citizenry away from its Protestant moorings. ${ }^{61}$ These evangelicals concluded that their divine calling was to establish God's kingdom on earth, employing America as its

\footnotetext{
${ }^{59}$ Frances FitzGerald, The Evangelicals: The Struggle to Shape America (New York: Simon \& Schuster, 2017), 2 .

${ }^{60}$ Randall Balmer, The Making of Evangelicalism: From Revivalism to Politics and Beyond (Waco, TX: Baylor University Press, 2010), 22.

${ }^{61}$ Gordon Conwell University, "Randall Balmer, Mark Massa, and John Fea-Politics and Evangelicals," May 8, 2019, video, 41:38, https://www.youtube.com/watch?v=jgHvJZ3FRfM
} 
inaugural launching pad. ${ }^{62}$ And their demurral on the imperilment of foreign inundation escalated steadily, as the number of Catholic Americans mushroomed from 5 percent in 1850 , to nearly 17 percent by the turn of the twentieth century. ${ }^{63}$

As this new era dawned, evangelical leaders encountered an onslaught from within, from a small contingent of liberal theologians, who were steadily gaining control of the movement's established institutions. ${ }^{64}$ These "modernists," as they were dubbed, discarded the Bebbington quadrilateral of salvation, replacing it with a "social gospel" that stressed benevolence toward the poor. This transmogrification was perhaps best instantiated by Charles Sheldon's 1896 landmark publication entitled, In His Steps, in which the Christian reader is posed with an elementary question that could serve as a shibboleth in all decision-making: "What Would Jesus Do" (WWJD)? However, the old evangelical guard (who called themselves "fundamentalists") decried this modish abandonment of doctrinal orthodoxy as a betrayal of "the faith." And at the end of the day, generally speaking, ardent antipathy toward "the social gospel resulted in [an evangelical] rejection of social justice." ${ }^{95}$

Evangelicals also stood aghast at the increasing encroachment of Darwinism within the United States educational system. A watershed moment arrived in 1925 with

\footnotetext{
${ }^{62}$ George Marsden, Religion and American Culture: A Brief History, (Grand Rapids, MI: Eerdmans Publishing, 2018), 65-66.

${ }^{63}$ Michael Gerson, "The Temptation: A Prominent Evangelical Writer Explains How His Movement Lost Its Way and Fell Hard for Trump," The Atlantic. April 2018. https://www.theatlantic.com/magazine/archive/2018/04/the-last-temptation/554066 (accessed February 27, 2020).

${ }^{64}$ Frances FitzGerald, The Evangelicals, 95-116.

${ }^{65}$ Michael Gerson. "The Temptation."
} 
the "Scopes-Monkey" Trial, in which William Jennings Bryant (an evangelical lawyer, former Secretary of State and Vice-Presidential nominee), served as the prosecuting attorney against John Scopes. ${ }^{66}$ The defendant was a Tennessee high school teacher, who stood accused of illegally indoctrinating students with the theory of evolution in his taxpayer-funded, public school classroom. A recording of the legal proceedings was broadcast across the country via radio, and though Bryant won the case, he lost in the court of public opinion.

Scopes' defense attorney, Clarence Darrow, made Bryant (as well as the evangelical Christianity he epitomized), look unsophisticated, unscientific, and antiintellectual. ${ }^{67}$ Ironically, Bryant died only five days after the trial concluded, as did evangelical hopes of wielding any significant sway within American culture for the foreseeable future. As a result, most of them monastically retreated from civic life, cocooning themselves (and especially their children) in a subculture of interconnected churches, schools, camps, publishing houses and other organizations. ${ }^{68}$ And for the most part, mainstream America ignored them, much like they do the Amish today. Many evangelicals cast aside politics entirely, washing their hands (proverbially speaking) of this sinful world's system, as they awaited the imminent return of Christ.

Over the previous quarter-century, evangelicals had grown increasingly disillusioned with post-millennialism, the "end-times" view, popularized during the

\footnotetext{
${ }^{66}$ George Marsden, Religion in American Culture, 173-175.

${ }^{67}$ John Fea, Was America Founded as a Christian Nation?, (Westminster: John Knox Press, 2011), 33, 44.

${ }^{68}$ Randall Balmer, Thy Kingdom Come (New York: Basic Books, 2007), 114-115.
} 
Second Great Awakening, which envisioned the entire world converting to Christ, to hasten His return to earth. ${ }^{69}$ Now it appeared as if the kingdom of God was in rapid retreat. And evangelicals gradually embraced a more pessimistic, premillennial eschatology, which foresaw the marginalization and persecution of believers intensifying, before Christ came back to personally inaugurate His eternal reign. ${ }^{70}$ As proof, they pointed to New Testament texts like 2 Timothy 3, where the Apostle Paul predicted: "In the last days perilous times will come .... [Evil men] will grow worse and worse, deceiving and being deceived" (vs. 1 and 13; see also 1 John 1:18 and Jude 1:18). ${ }^{71}$ So eventually, most evangelicals determined to hunker down, hold on until the rapture (see 1 Thessalonians 4:16), and seek to help save as many souls as possible in the interim.

However, by the 1940s, a generation of "new" evangelicals began to emerge, aggregated by the founding of the National Association of Evangelicals in 1942. The NAE was comprised of churches from dozens of denominations, totaling about two million members at the time of its inception. ${ }^{72}$ This syndicate coalesced around the Bebbington quadrilateral, while also seeking to reconcile sacred Scripture with science, scholarship and the practice of social justice and civic engagement. Their chief spokesperson was Billy Graham, who by the mid-1950s had severed ties with his former "fundamentalist," associates, whom he deemed inordinately sectarian (both

\footnotetext{
${ }^{69}$ Randall Balmer, The Making of Evangelicalism, 27.

${ }^{70}$ Philip Gorski, "Why Evangelicals Voted for Trump: A Critical Cultural Sociology," American Journal of Cultural Sociology 5:3 (July 31, 2017): 341.

${ }^{71}$ All biblical texts in this work are quoted from the New King James Version.

72 Jonathan Merritt, "Defining 'Evangelical.,”
} 
ecclesiastically and racially). Graham was probably chiefly responsible for reintroducing evangelicalism into mainstream American culture again, through his preaching crusades and by founding (in 1956), what arguably became evangelicalism's most strategic literary voice, the magazine called "Christianity Today." Graham, who was called "America's pastor," became a counselor and confidant to presidents and politicians across America and around the world, who sought to openly identify with the panjandrum, to project a respect for religion and faith to potential supporters. ${ }^{73}$

During the 1960s, it seemed to many evangelicals that the moral fiber of American society was deteriorating at break-neck speed. The Supreme Court prohibited official, government-sponsored prayer in public school classrooms in 1962 (Engel v. Vitale), along with compulsory Bible reading the following year (Abington School District v. Schempp, 1963). The Civil Rights Act of 1964 mandated strict enforcement of school desegregation, which many evangelicals (especially in the south) claimed defied God's command to disassociate the races into distinct groups at the Tower of Babel (see Genesis 11:8). The Hart-Cellar, Immigration Act of 1965 then opened the nation's borders to a massive influx of migrants from countries which did not principally subscribe to Protestant-evangelical traditions. Other alleged defiling influences of the 1960s included the sexual revolution, the drug counterculture, and the feminist movement. And this downward spiral appeared to culminate in the 1973 SCOTUS decision of Roe v. Wade, which substantially expanded abortion rights for women.

${ }^{73}$ John Fea, Believe Me: The Evangelical Road to Donald Trump. Eerdmans Publishing (Grand Rapids, MI: 2018), 145. 
However, a new day seemed to be dawning for evangelicals in 1976, when one of their own, Jimmy Carter (a self-professing "born-again," southern Baptist Sunday School teacher) won the presidency on the Democratic ticket. ${ }^{74}$ But though they immensely appreciated Carter's character and comportment, many evangelicals were deeply disappointed by his policies on controversial social issues like abortion, homosexuality and the desegregation of public schools, which they believed failed to conform to sacred Scripture. $^{75}$

During the 1970s, the IRS also began cracking down on high-profile, faith-based schools, which discriminated against students of color, in respect to their policies of admission and conduct. In 1971, the Supreme Court affirmed (in Green v. Connally), that private elementary and secondary schools which refused to admit blacks, could be denied tax-exempt status by the Internal Revenue Service. And in January of 1976, the IRS likewise clamped down on Bob Jones University (the most prominent fundamentalistevangelical educational institution of its day) due to its racially discriminatory policies. ${ }^{76}$ According to Randall Balmer (evangelical professor of history at Dartmouth University), BJU had denied entrance to black students entirely up until 1971, and thereafter had enforced strict prohibitions against interracial dating. ${ }^{77}$ Based on Acts 17:26, Bob Jones Sr. had declared: "God created every human nation to live on the whole earth, having

\footnotetext{
${ }^{74}$ Randall Balmer, Thy Kingdom Come, 169.

${ }^{75}$ John Fea, Was America Founded," 54.

${ }^{76}$ Randall Balmer, The Making of Evangelicalism, 63.

${ }^{77}$ Randall Balmer, "The Real Origins of the Religious Right," Politico. May, 27, 2014. https://www.politico.com/magazine/story/2014/05/religious-right-real-origins-107133\#.U4eDQ_ldW2E (accessed February 28, 2020).
} 
determined the ... boundaries of their lands .... [And one] cannot run over God's ... established order without having trouble. God never meant to have one race." ${ }^{178}$ The South Carolina school appealed its case all the way to the U.S. Supreme Court and lost in 1983 (Bob Jones University v. United States).

Jerry Falwell, Baptist televangelist and president of Liberty Christian Academy and University, likewise seemed to have been committed to racial segregation in education. Max Blumenthal (an American author and filmmaker) transcribed the following excerpts from a sermon Falwell preached (entitled "Segregation or Integration: Which?"): "If Chief Justice Warren and his associates had known God's word and had desired to do the Lord's will, ... the 1954 decision [Brown v. Board of Education] would never have been made .... When God has drawn a line of distinction, we should not attempt to cross that line .... The true Negro does not want integration .... He realizes his potential is far better among his own race."79

Randal Balmer deprecatingly theorized that the potential loss of tax-exempt status for Falwell's academic institutions, due to racial discrimination, was the ultimate, critical impetus for his galvanizing thousands of evangelical ministers (along with conservative Jews, Catholics and Mormons) into the "Moral Majority," an organization that he founded in June of $1979 .{ }^{80}$ According to Balmer, Falwell got the name of this group from

\footnotetext{
${ }^{78}$ Justin Taylor, "Is Segregation Scriptural? A Radio Address from Bob Jones on Easter of 1960," The Gospel Coalition. July 26, 2016. https://www.thegospelcoalition.org/blogs/evangelicalhistory/is-segregation-scriptural-a-radio-address-from-bob-jones-on-easter-of-1960/ (accessed February 27, 2020).

${ }^{79}$ Max Blumethall, "Agent of Intolerance," The Nation. May 16, 2007. https://www.thenation.com/article/archive/agent-intolerance (accessed February 28, 2020).

${ }^{80}$ Frances FitzGerald, The Evangelicals," 291.
} 
Paul Weyrich, a Republican strategist, ${ }^{81}$ who had been trying to mobilize evangelicals to support GOP candidates since 1964. Balmer alleged that Weyrich admitted privately that he had promised evangelicals to reinstate prayer and Bible reading in public schools, along with marshalling intense opposition against feminism, pornography, homosexuality, and abortion. And he reportedly claimed that nothing had worked, until finally, the IRS crackdown on racial discrimination, rallied the religious right to return to the ballot box once again. ${ }^{82}$ In 1979, Falwell announced that he and his fellow ministers had three top priorities: to get people "saved," then "baptized" and then "registered to vote." $" 83$

Contrary to Balmer's narrative, it is commonly avouched that the issue of abortion catalyzed Falwell's "Moral Majority.” But according to Balmer, the Baptist minister had personally acknowledged that the first time he had ever spoken out publicly against abortion was in February of $1978 .{ }^{84} \mathrm{Up}$ until that time, abortion had consistently been considered an almost exclusively Catholic issue. ${ }^{85}$ Balmer wrote:

In $1968, \ldots$ a symposium sponsored by the Christian Medical Society and Christianity Today, ... . refused to characterize abortion as sinful, citing 'individual health, family welfare, and social responsibility' as justifications for ending a pregnancy. In 1971, delegates to the Southern Baptist Convention in St. Louis, Missouri, passed a resolution encouraging 'Southern Baptists to work for

\footnotetext{
${ }^{81}$ Randall Balmer, Thy Kingdom Come, 13-15.

${ }^{82}$ Randall Balmer, “The Real Origins.”

${ }^{83}$ Retro Report, “The Roots of Evangelicals' Political Fervor,” October 28, 2018, video, 11:15, https://www.youtube.com/watch?v=nAzPVhn-drU\&t=122s

${ }^{84}$ N.A., "The Man Who Mobilized the Evangelical Vote. April 15, 2018, video, 10:18. https://www.youtube.com/watch?v=BcC53j32BW4

${ }^{85}$ Russel Moore, "The Gospel According to Jane Roe: Abortion Rights and the Reshaping of Evangelical Theology," Southern Baptist Journal of Theology 7 (Summer 2003): 41.
} 
legislation that will allow the possibility of abortion under such conditions as rape, incest, clear evidence of severe fetal deformity, and carefully ascertained evidence of the likelihood of damage to the emotional, mental, and physical health of the mother.' The convention, hardly a redoubt of liberal values, reaffirmed that position in 1974, one year after Roe, and again in $1976 .{ }^{86}$

Also, the SBC's well-known former president, W. A. Criswell, stated after the 1973

SCOTUS ruling (in Roe v. Wade), "I have always felt that it was only after a child was born and had a life separate from its mother that it became an individual person." 87

Balmer theorized that Falwell concluded that, although the loss of his schools' tax-exempt status, due to racial discrimination, was a clear threat to evangelical religious liberty (not to mention his ministry's financial survival), this would be an onerous point around which to rally the religious masses. So, he and his cohorts ultimately converged instead around opposing abortion. ${ }^{88}$ And a popular 1979 film series called "Whatever Happened to the Human Race," produced by evangelical scholar, Francis Schaeffer, engendered widespread abhorrence for the practice throughout the broader religious community. ${ }^{89}$ Ed Dobson (co-founder of the "Moral Majority"), allegedly confessed to Balmer: "I sat in the non-smoke-filled back room with [our leaders], and I frankly do not remember abortion [early on], ever being mentioned as a reason why we ought to do something." 90

\footnotetext{
${ }^{86}$ Randall Balmer, “The Real Origins.”

${ }^{87}$ Ibid.

88 Ibid.

${ }^{89}$ John Fea, Was America Founded, 9.

${ }^{90}$ Randall Balmer, Thy Kingdom Come, 16. This study did not unearth any primary-source documentation which verified that Weyrich or Dobson confirmed the statements that they allegedly made to Balmer in private (noted above), regarding Falwell's principal motivation for founding the "Moral Majority."
} 
All throughout the 1980 presidential campaign, evangelicals were vigorously courted by Republican candidate, Ronald Reagan, who promised to be their policy advocate in Washington D.C. This was an unlikely alliance, given the fact that the former Hollywood actor had been divorced and remarried; his wife consistently consulted astrologers to provide him counsel; and as governor of California, he had signed legislation in support of abortion..$^{91}$ However, politics makes strange bedfellows. And in August of 1980, Reagan stated the following at the "National Affairs Campaign Address on Religious Liberty:"

[This is] a time when traditional Judeo-Christian values based on the moral teaching of religion are undergoing what is perhaps their most serious challenge in our nation's history .... Under the pretense of separation of Church and State, religious beliefs cannot be advocated in many of our public institutions, but atheism can .... The First Amendment was written not to protect the people and their laws from religious values, but to protect those values from government tyranny .... We have God's promise that if we turn to him and ask His help, we shall have it. With His help, we can still become that shining 'city upon a hill ... $\therefore$ When the Israelites were about to enter the Promised Land, they were told that their government and laws must be models to other nations, showing to the world the wisdom and mercy of their God. To us, as to the ancient people of the promise, there is given an opportunity: a chance to make our laws and government not only a model to mankind, but a testament to the wisdom and mercy of God. ${ }^{92}$

During his campaign, Reagan also vowed to nominate pro-life judges; preserve religious freedom (especially from the IRS "regulatory agenda" of going after "independent

However, given the verifiable and circumstantial evidence that has been outlined, Balmer's theory (noted above) is certainly plausible and seems reasonably credible.

${ }^{91}$ Martin Medhurst, "The Religious Rhetoric of Anti-Trump Evangelicals in the 2016 Presidential Election," Res Rhetorica (February 2017): 4.

${ }^{92}$ Life Today, “James Robison: National Affairs Briefing,” March 13, 2014, video, 25:57 https://www.americanrhetoric.com/speeches/ronaldreaganreligiousliberty.htm (accessed 2 February 2020). 
schools"); and reintroduce prayer and bible reading back into public school classrooms. ${ }^{93}$ Reagan eventually won evangelicals' hearts, along with the 1980 presidential election. And the truncated transcript from his speech (cited above), succinctly outlined the patented GOP playbook of appeal, which Republican candidates have used to woo evangelical voters ever since.

Although Reagan mastered their religious rhetoric, he accomplished little while in office, in respect to the policies evangelicals prioritized. So, in 1988, Pat Robertson (a southern Baptist, Charismatic televangelist) mounted a brief, but surprisingly popular campaign bid for the Republican party's presidential nomination. And the following year, Robertson also founded “The Christian Coalition,” which did yeoman's work in organizing evangelicals on the ground, as an integral arm of the GOP. ${ }^{94}$

Republican, George H. W. Bush, won the 1988 presidential contest, but he was never extremely well-received by evangelicals and effectuated even less of their policy agenda than his predecessor. ${ }^{95}$ And then evangelicals felt almost completely disenfranchised during Bill Clinton's tenure in office (from 1993-2001), as the progressive backlash from twelve years of a GOP-controlled White House, hit them like a ton of bricks.

But finally, in the campaign of 2000, evangelicals had one of their own to support once again. George W. Bush had laid claim to his own "born again" experience, with the

\footnotetext{
93 Randall Balmer, "The Real Origins.”

${ }^{94}$ George Marsden, Religion in American Culture, 249.

${ }^{95}$ Frances FitzGerald, The Evangelicals, 414.
} 
help of evangelist, Billy Graham. ${ }^{96}$ And the Texas governor promised to be their staunch policy advocate in the nation's capital once more. Bush regularly sought evangelicals' input and even selected several of them to serve in high positions within his government. Most evangelicals strongly backed his "war on terror," largely due to the protection it secured for Israel in the Middle East. The Republican president also took steps to protect religious freedom and increase abortion restrictions, while advocating for a ban on samesex marriage at the federal level. And these actions likely insured evangelical support for his reelection bid in 2004, which experts suggest may have been the catalyst for his victory, because of their impact in crucial, battleground states. ${ }^{97}$ In addition, Bush nominated his personal assistant to the Supreme Court, an evangelical jurist named Harriet Miers, though she eventually withdrew from the confirmation process. However, he did ultimately get two conservative judges appointed to the bench: John Roberts and Samuel Alito.

Then from 2009-2017, evangelicals felt patently edged out once again during the presidency of Barack Obama. His 2010 “Affordable Care Act” required employers to provide birth control options (some of which were abortifacient) in their employee health plans. Then religious business owners were pressured to service same-sex weddings. Transgender students were granted access to the public-school gender's bathroom of their choice. And in 2015, the Supreme Court legally redefined marriage to include same-sex couples (Obergefell v. Hodges). ${ }^{98}$

\footnotetext{
${ }^{96} \mathrm{Ibid}, 457$.

${ }^{97}$ Ibid, 482.
} 
Moreover, just seven months later, California lawmakers introduced SB1146, a test-balloon bill, which economically imperiled faith-based, higher educational institutions that discriminated against LGBT students. Not only did SB1146 order the withholding of state grant funds from all students attending these schools, but legal experts warned that the measure's vague wording could also open the door for civil litigation, thereby threatening the very future existence of all non-compliant colleges and universities. The "bill had no bearing on the federal funding [of] institutions outside California, but it still raised much fear among Christian colleges throughout the country." 99 As a result, dozens of America's most influential evangelicals, united with other faith-leaders to lobby for its defeat (with a total of 139 of them signing a statement to that effect in August of 2016). ${ }^{100}$ And in the end, the bill was temporarily tabled.

For many years, "the Obama administration had been moving to limit federal funds to organizations that 'discriminated' against the LGBT community." And John Fea pertinently noted that Liberty University students, for example, received $\$ 445$ million in annual federal loans. So, "it may not be too much of an exaggeration to say that the future of Liberty University as the world's largest Christian university may have been in jeopardy [if] Hillary Clinton won the Presidency in November 2016." ${ }^{101}$ In many ways, history did seem to be repeating itself in the run-up to the 2016 election.

\footnotetext{
${ }^{98}$ George Marsden, Religion in American Culture, 258.

${ }^{99}$ John Fea, Believe Me, 141.

100 N.A., "Protecting the Future of Religious Higher Education," The Ethics \& Religious Liberty Commission of the Southern Baptist Convention. August 9, 2016. https://erlc.com/resourcelibrary/statements/protecting-the-future-of-religious-higher-education (accessed March 10, 2020).

${ }^{101}$ John Fea, Believe Me, 141.
} 


\section{CHAPTER THREE}

\section{EVANGELICAL SUPPORT FOR TRUMP}

This chapter will outline the key reasons why the majority of evangelicals supported Donald Trump in the 2016 presidential race. It will discuss evangelical theology (which undergirds their belief system); evangelical access (which Trump provided them within his administration); and evangelical policies (which Trump promised to champion). Though numerous works will be cited in this chapter, it will focus on related assertions made by five extremely prominent evangelical leaders, who supported Trump: Jerry Falwell Jr., Franklin Graham, Robert Jeffress, Pat Robertson, and James Dobson. None of these individuals tended to write prolifically for journalistic or scholarly-oriented publications, so this study will primarily cite statements that they made through television and social media-related venues.

\section{Evangelical Theology}

By way of introduction, it is important to consider the contributions of scholars who focused on how religious teaching can affect the political positions that voters embrace. Anna Grzymala-Busse noted that religions encourage "shared ideas about legitimate political authority" among their adherents. ${ }^{102 ~ " D o c t r i n a l ~ d i f f e r e n c e s ~ t r a n s l a t e ~}$ into distinct patterns . . . and policy preferences .... [So, one must $]$ take doctrine seriously, both as a source of unique identity and as a powerful demarcation of

102 Anna Grzymala-Busse, "Why Comparative Politics Should Take Religion (More) Seriously," Annual Review of Political Science 15 (2012): 424. 
institutional preferences." 103 "Even small doctrinal differences can ... [make] religious identities uniquely costly to change .... Apostates (those who abandon a religious tradition) and heretics (those who adopt unorthodox religious views) are the transgressors most heavily punished by religious bodies." 104

Another study by John Bartkowski, Aida Ramos-Wada, Chris Ellison and Gabriel Acevedo concluded that "conservative Protestantism is a more 'costly' faith because it places stricter, more rigorous demands on its adherents" than many other religious sects impose. ${ }^{105}$ And these scholars found that the more frequently a person attended worship services, the more likely they were to embrace many conservative policy positions. ${ }^{106}$ Ran Hirschl and Ayelet Shachar highlighted that there was a "clash of orders" for religious voters, due to "the strategic reliance on religious identity markers to generate unequal civic standings among formally equal citizens." 107 This creates “"us versus them' collective-identity narratives, ... thus countering much of the agenda that has become associated with individual-rights-centered liberal constitutionalism." ${ }^{108}$ However, Michael Evans' research concluded that religious voters are typically willing to accept

\footnotetext{
${ }^{103}$ Ibid., 438.

${ }^{104}$ Ibid., 422, 425.

105 John P. Bartkowski, Aida I. Ramos-Wada, Chris G. Ellison and Gabriel A. Acevedo, "Faith, RaceEthnicity, and Public Policy Preferences: Religious Schemas and Abortion Attitudes Among U.S. Latinos," Journal for the Scientific Study of Religion, 51:2 (June 2012): 356.

106 Ibid., 345.

${ }^{107}$ Ran Hirschl and Ayelet Shachar, "Competing Orders? The Challenge of Religion to Modern Constitutionalism,” The University of Chicago Law Review 85:2 (March 2018): 425.

${ }^{108}$ Ibid., 455.
} 
the results of the political process, once they have exhausted all their legal options, due to their desire to maintain civil order. ${ }^{109}$

Finally, William Blake insisted that it was not possible for a person to "suppress her or his values" when making political decisions, no matter how much they desired to do so. And Blake added that most Protestant "denominations reject religious hierarchies," so individual congregants had liberty to interpret Scripture according to their own consciences, due to the doctrine of the individual 'priesthood' of all believers."

In respect to the evangelical movement specifically, it is essential to note that it is not monolithic. There is no individual, council or group which can speak authoritatively for its adherents. In fact, the majority of evangelical congregations are independent, rejecting denominational ties or mandatory restrictions imposed by any outside entity. So, their final authority for faith and practice is the Bible, as it is interpreted by their individual congregations. Therefore, to understand evangelical support for Trump, it is absolutely essential for one to gain a sufficient grasp of the movements' pertinent theological underpinnings, as derived from their sacred Scriptures.

Consequently, using my own professional expertise in this academic field, ${ }^{111}$ as well as explicative references from the five extremely prominent evangelical leaders cited

\footnotetext{
${ }^{109}$ Michael S. Evans, "Religion and Political Decision Making," Journal for the Scientific Study of Religion, 53:1 (March 2014): 153, 160.

${ }^{110}$ William Blake, "God Save This Honorable Court: Religion as a Source of Judicial Policy Preferences," Political Research Quarterly, 65:4 (December 2012): 814-816.

${ }^{111}$ I attended four prominent evangelical colleges and universities, completing a Doctor of Philosophy in theological studies from Trinity Evangelical Divinity School (Deerfield, IL). I have also served as a professor at two evangelical institutions of higher learning: teaching Bible and theology both at Northland Baptist Bible College (Dunbar, WI) from 1996-2006, and at Multnomah University (Portland, OR) from 2008-present. In addition, I have served as the lead pastor of three evangelical churches, from three distinct
} 
above (among others), I will provide that necessary illumination of relevant biblical teaching throughout this chapter. This is the indispensable, "missing piece of the puzzle," that causes evangelical support for Trump to remain such a mystery to most Americans. But unfortunately, the review of evangelical works that was conducted for this study, did not unearth relevant, serviceable scholarly literature, which satisfactorily explained how religious teaching affects the political positions that evangelicals take. That is one of the primary contributions that this thesis will make to the corpus of related literature.

There are numerous salient biblical texts which evangelical leaders frequently cite, that have helped give rise to what many have dubbed, the doctrine of "Christian nationalism." This is "an ideology that fuses Christians' love of God and country, ... rejects secular society and seeks to [leverage] Christians' influence in the public sphere." 112

One textual example is Proverbs 14:34, which proclaims that "righteousness exalts a nation, but sin is a reproach to any people." Therefore, many evangelicals believe that "no man is an island to himself." How an individual citizen acts, as well as the collective decisions which a society makes, can result (under divine providence) in either their exaltation or humiliation for generations to come. So, many evangelical leaders like Jerry Falwell Jr., have advocated that believers have a moral and ethical obligation to

evangelical sub-groups, for a total of twelve years: a Bible Church (1998-2006); a Church of God (2007); and a Baptist Church (2010-2012).

${ }^{112}$ Carol Kuruvilla, "Researchers Discover Common Thread Among Christians Who Voted For Trump," Huffington Post. April 4, 2018 https://www.huffpost.com/entry/researchers-discover-common-threadbetween-evangelicals-who-voted-for-trump_n_5abbd15ae4b04a59a313c5ea (13 February 2020). 
encourage the practice of "righteousness" (viz., obedience to God's commands in Scripture) in American life. ${ }^{113}$

Another oft-repeated text is Psalm 33:12a, which says, "blessed is the nation whose God is the Lord, the people He has chosen as His own inheritance." In context, this passage refers to the theocracy of Israel, the Lord's "chosen" people (according to the Old Testament). However, many evangelical leaders like Franklin Graham, assert, that America was similarly established under the auspices of a unique (though extrabiblical) divine covenant, as a "Christian nation."114 Evangelical historians like David Barton, Peter Marshal, and David Manuel, have frequently made the case that most of the country's noteworthy founding fathers were believers, or at least were decidedly sympathetic to evangelical values. ${ }^{115}$ But evangelical leaders like Dave Brody and Scott Lamb insisted that, over time, the United States has woefully backslidden from its forefathers' puritanical ambition of becoming a "city on a hill" (a phrase borrowed from Jesus in Matthew 5:14 by Puritan politician, John Winthrop in his famous 1630 sermon). ${ }^{116}$ Thus, it has shirked its divine call to showcase God's blessing of prosperity and protection, which He promised to reward to any "righteous" nation, that other

\footnotetext{
113 Jerry Falwell, “A True Memorial Day,” Sermon Central. September 17, 2000. https:/www.sermoncentral.com/sermons/a-true-memorial-day-jerry-falwell-sermon-on-principles-139230 (accessed March 2, 2020).

${ }^{114}$ Billy Hallowell, “'Our Nation Is in Trouble:' Franklin Graham Warns That 'We've Turned Our Back on God' — but He Has a Bold Plan to Fight Back," The Blaze. December 31, 2015. https://www.theblaze.com/news/2015/12/31/our-nation-is-in-trouble-franklin-graham-warns-that-weveturned-our-back-on-god-but-he-has-a-bold-plan-to-fight-back (accessed March 2, 2020).

115 There are numerous evangelical works which makes this argument, including David Barton's, America's Godly Heritage and Peter Marshal's and David Manuel's book, The Light and the Glory.

${ }^{116}$ Dave Brody and Scott Lamb, The Faith of Donald Trump: A Spiritual Biography (New York: Harper Collins Publishers, 2018), 45.
} 
people-groups around the world could admire and also procure, if they would embrace Christianity. ${ }^{117}$

Many evangelicals attribute the unparalleled prosperity and hegemonic influence over global affairs that the United States has long enjoyed, as having been divinely bequeathed as a reward for its exceptional (though certainly not flawless) historic obedience to the Bible's commands. However, the nation's glory has largely departed, and its greatness has gradually eroded away, because its citizens have turned their backs on God. And according to evangelical leader, Robert Jeffress, the cure is to claim Yahweh's promise to Israel in 2 Chronicles 7:14: "If my people, who are called by my name, will humble themselves, and pray and seek my face, and turn from their wicked ways, then will I hear from heaven, and will forgive their sin and heal their land." 118

To solicit God's blessing on America, evangelicals who were sympathetic to this type of Christian nationalistic thinking, have historically sought to support political candidates who they believed best exemplified and upheld their values. And they typically endorsed the "lesser of two evils," when forced to choose between candidates who are less than ideal. However, voting for Trump in 2016, may have pushed that pragmatism to its limits for the faithful. But in light of the titanic threat that secular forces posed to America's "righteousness," many of them became convinced that Trump was

\footnotetext{
${ }^{117}$ Rebecca Barrett-Fox, “King Cyrus President,” 506.

118 Robert Jeffress, “Dr. Robert Jeffress Responds to San Bernardino Terrorist Attacks,” Dr. Robert Jeffress Pathway to Victory. N.D. https://ptv.org/dr-robert-jeffress-san-bernardino-terrorist-attacks/ (accessed March 2, 2020).
} 
their last hope of stemming the overwhelming tide of liberal degeneracy and staving off God's judgment. ${ }^{119}$

Like virtually every Republican presidential candidate since Ronald Reagan, Trump made strong, consistent appeals to Christian nationalism throughout his campaign. ${ }^{120}$ For example, in January of 2016, he stated at Liberty University,

We are going to protect Christianity. And if you look at what's going on throughout the world, . . . if you're Christian, they're chopping off heads. . . . [Christianity is] under siege. I'm a Protestant. I'm very proud of it . . . I'm very proud of it, very, very proud of it . . . . Other religions, frankly, they're banding together .... If you look at this country, it's gotta be 70 percent, 75 percent [Christian], some people say even more - the power we have, somehow, we have to unify. We have to band together ... . Our country has to do that around Christianity. ${ }^{121}$

Also, in January of 2016, Trump declared at Oral Roberts University: “There is an assault on Christianity .... There is an assault on everything we stand for, and we're going to stop the assault." 122 Later that August, he said to a large gathering of Florida evangelical pastors: "[Christianity] has had a very, very tough time — very tough time .... We're going to bring [Christianity] back because it's a good thing. It's a good thing. They

\footnotetext{
119 Rebecca Barrett-Fox, "King Cyrus President," 502.

${ }^{120}$ Unless otherwise noted, the citations on the following two pages of this thesis were catalogued by Andrew Whitehead and Samuel Perry in "Make America Christian Again: Christian Nationalism and Voting for Donald Trump in the 2016 Presidential Election." Sociology of Religion: A Quarterly Review. 29:2 (2018), 151-153.

${ }^{121}$ C-Span, "Presidential Candidate Donald Trump at Liberty University," January 18, 2016, video, 50:00. https://www.c-span.org/video/?403331-1/donald-trump-remarkslibertyuniversity

122 Jessilyn Justice and Taylor Berglund, "Trump, Palin Challenge ORU Students to Launch 'Great Awakening,"” Charisma News. January 20, 2016. https://www.charismanews.com/ politics/54595-trump-palin-challenge-oru-students-to-launch-great-awakening (Accessed February 22, 2020).
} 
treated you like it was a bad thing, but it's a great thing." ${ }^{\prime 23}$ And in the following month, Trump exhorted a group of African American evangelical ministers, "now, in these hard times for our country, let us turn again to our Christian heritage, to lift up the soul of our nation." 124 Also in September, Trump solemnly warned Pat Robertson, during a televised interview, “if we don't win this election, you'll never see another Republican and you'll have a whole different church structure - a whole different Supreme Court structure."125 And after assuming office (in May of 2017), Trump assured his audience at the Liberty University commencement ceremony, “as long as I am your president no one is ever going to stop you from practicing your faith or from preaching what's in your heart. We will always stand up for the right of all Americans to pray to God and to follow His teachings." 126

Rebecca Barret-Fox (professor of sociology at Arkansas State University) insightfully noted:

Religious right leaders and voters in the United States supported Donald Trump in the 2016 presidential election for the same reason that all blocs vote as they do: They believed that the candidate offered them the best opportunity to protect and extend their power and create their preferred government. The puzzle of their

\footnotetext{
${ }^{123}$ C-Span, "Donald Trump Remarks in Orlando, Florida," August 11, 2016, video, 46:04. https://www.c-span.org/video/?413877-1/donald-trump-addresses-evangelicalleadersorlando-florida

${ }^{124}$ C-Span. 2016c. "Presidential Candidate Donald Trump Remarks in Detroit." Video Posted by C-Span. September 3. https://www.c-span.org/video/?414743-1/donald-trump-speaksafricanamericanchurch-detroit.

${ }^{125}$ Martin Pengelly, “Trump Predicts Demographics Make 2016 'Last Election Republicans Can Win," The Guardian. September 9, 2016. https:/www.theguardian.com/us-news/2016/sep/09/trumpdemographics-2016-election-republicans-can-win (accessed February 27, 2020).

${ }^{126}$ C-Span, "Liberty University Commencement Address,” May 13, 2016, video, 58:57. https://www.cspan.org/video/?428429-1/president-trump-delivers-liberty-universitycommencementaddress\&live
} 
support, then, is less why they chose Trump and more how they navigated the process of inserting Trump into their story of themselves as a 'moral' majority. ${ }^{127}$

In that endeavor, many evangelical leaders attributed Trump's presidency to the sovereign selection of God, noting numerous biblical texts which indicated that He alone places all political leaders in power. For example, Psalm 75:6-7 declared, "exaltation comes neither from the east nor from the west nor from the south. But God is the Judge: He puts down one [political leader], and exalts another." The Apostle Paul also stated in Romans 13:1, "let every soul be subject to the governing authorities. For there is no authority except from God, and the authorities that exist are appointed by God" (see also Matthew 22:31 and 1 Peter 2:13-14).

In light of biblical texts like these, Pat Robertson concluded on his evangelical television show, The 700 Club, that "God put His hand" on Trump, to raise him up as president. ${ }^{128}$ On the same broadcast, Stephen Strang (evangelical CEO of Charisma Media) identified Trump's victory as an answer to Christians' prayers, noting that the former playboy had "cleaned up his act," about a decade prior to his campaign. Strang's book, God and Donald Trump, recorded numerous prophetic words, that he claimed had been catalogued by evangelical leaders ahead of time, about Trump's forthcoming ascendance to the Oval Office. Strang also revealed that God had spoken to him personally, stating that He was "raising [Trump] up like Cyrus," a famous Persian king in the Old Testament (see 2 Chronicles 36:22-23; Ezra 1-6; Isaiah 44:28-45:13; and Daniel

\footnotetext{
${ }^{127}$ Rebecca Barrett-Fox, "King Cyrus President," 502.

${ }^{128}$ The 700 Club, "Recognizing God's Hand in Donald Trump's Election," November 6, 2017, video, 12:33. https://www.youtube.com/watch?v=aRcnJPQqY0c
} 
1:21, 6:28; 10:1). ${ }^{129}$ According to a prediction of the biblical prophet, Isaiah (which many evangelicals asserted was announced about 150 years before its fulfillment in 539

B.C.E.), God would exalt and enrich Cyrus, so that he could send the Israelites back from captivity and finance the rebuilding of their homeland. Isaiah 44:28-45:4 records, "[the LORD] says of Cyrus, 'He is My shepherd, And he shall perform all My pleasure,' saying to Jerusalem, 'You shall be built,' and to the temple, 'Your foundation shall be laid. ...' I will give you the treasures of darkness and hidden riches of secret places .... [For] Israel My elect, I have even called you by your name, ... though you have not known Me."

Many evangelicals noted that like Cyrus, who had not previously "known" God, Trump also may not have ever been (or ever become) a true, born-again believer. However, God could still use him to prosper America, advance His kingdom, and protect His followers, by stifling the insidious leaven of progressive liberalism. ${ }^{130}$ Evangelicals offered additional comparisons of Trump to biblical characters, including the Israelite champions, Samson (see Judges 13-16) and Jehu (see 2 Kings 9). ${ }^{131}$ Both of these leaders' lives were characterized (to varying degrees) by unrighteousness, but God still used them to advance Jewish national interests. And even more favorable comparisons of Trump were made to David (a repentant adulterer, whom God later called "a man after

\footnotetext{
${ }^{129}$ Ibid.

${ }^{130}$ Ben Howe, The Immoral Majority: Why Evangelicals Chose Political Power Over Christian Values (HarperCollins Publishing, 2019), 49.

${ }^{131}$ Ibid., 57.
} 
my own heart," see Acts 13:32); ${ }^{132}$ Solomon (a man with many wives, 1 Kings 11:3); ${ }^{133}$ and to Nehemiah, who courageously oversaw the reconstruction of his own "wall" around Israel's capitol city, despite intense opposition from his enemies (see Nehemiah $1-6){ }^{134}$

Trump identified himself as a Presbyterian Christian, having been baptized while attending Sunday School in childhood. And as a young adult, he frequented New York's Marble Collegiate Church (a liberal Presbyterian congregation), where Norman Vincent Peale then served as pastor. ${ }^{135}$ However, the infamously hedonistic real estate mogul had no background within evangelical circles and has yet to make an official profession of "salvation." Though his long-time spiritual advisor, Paula White asserted that after multiple, in-depth conversations with him about faith, she was convinced that he had been truly "born again." 136 Incidentally, White was a former model, who was typically associated with the Christian "prosperity gospel" movement. ${ }^{137}$ And back in 2011, after watching one of her televised sermons, Trump called White to introduce himself to her for the first time. Shortly thereafter, she recruited twenty-five fellow evangelical notables for a visit to Trump Tower, where he explored with them the possibility of a presidential

\footnotetext{
132 Dave Brody, et al., The Faith of Donald Trump, 220.

${ }^{133}$ Ben Howe, The Immoral Majority, 57.

${ }^{134}$ Mark J. Rozell and Clyde Wilcox, eds., God at the Grassroots, 2016: The Christian Right in American Politics (Lanham, MD: Rowman \& Littlefield, 2018), 185.

135 John Fea, Believe Me, 137.

${ }^{136}$ NBC. "Meet The Woman Who Many Call President Elect Donald Trump's Spiritual Adviser". Filmed [January 2017]. January 19, 2017, video, 2:13. https://www.youtube.com/watch?v=-3-whDsYvTU

${ }^{137}$ Kenneth Woodward, "How Religion Got Trump: Faith in 2016 Election,” Commonweal (May 18, 2018): 19 .
} 
run in 2012 (which did not ultimately materialize). ${ }^{138}$ However, White was eventually honored by Trump with the opportunity to lead the nation in prayer at his inauguration ceremony in January of 2017. And she has served as one of his chief liaisons to, and representatives of, the evangelical community ever since. ${ }^{139}$

\section{Evangelical Access}

In 2016, few Americans would have considered either Donald Trump, or his Democratic challenger, Hillary Clinton as a paragon of virtue. Clinton's reputation had been tainted for decades, predominantly due to her intimate association with the numerous, high-profile scandals that plagued her husband's political career. ${ }^{140}$ She also was not a professing evangelical Christian and made almost no attempt to reach out to their community. And she espoused numerous policy positions, which evangelicals adamantly opposed. For example, in addition to supporting same-sex marriage, while addressing the "Women in the World Summit" in 2015, on the importance of maintaining abortion rights, she seemed to threaten the very foundations of American religious liberty by stating that "deep-seated cultural codes, religious beliefs and structural biases have to

\footnotetext{
${ }^{138}$ Senate Finance Committee, "Minority Staff Review of Without Walls International Church Paula White Ministries," Senate.gov. 2011. https://www.finance.senate.gov/imo/media/doc/WWIC\%20Whites\%200105-11.pdf (accessed March 2, 2020).

${ }^{139}$ Nina Burleigh, "Does God Believe in Trump? White Evangelicals are Sticking with Their 'Prince of Lies'; Evangelicals Worship Their President but Seem Blind to the Multitude of Signs that Donald Trump's Holy Trinity is 'Me, Myself and I."' Newsweek. October 13, 2017. https://www.newsweek.com/2017/10/13/donald-trump-white-evangelicals-support-god-677587.html (accessed February 18, 2020).

${ }^{140}$ CBS News, "Why Evangelical Christians Still Support President Trump Despite Controversies," March 27, 2018, video, 9:28. https://www.youtube.com/watch?v=miROBFtuEYE
} 
be changed."141 Many evangelicals even perceived her as being openly hostile toward them, especially after she publicly referred to "half" of Trump's supporters as being in a "basket of deplorables," just two months prior to the election. ${ }^{142}$

Trump, on the other hand, made every effort to ingratiate himself to evangelicals and court their support, offering their leaders significant access to his campaign. In June of 2016, he assembled an official "Faith Advisory Board," comprised of their community's top-tier movers and shakers, including James Dobson (founder of "Focus on the Family"); Paula White and Gloria Copeland (both prominent pastors and televangelists); Jerry Falwell Jr. (practicing lawyer and president of Liberty University, the largest Christian educational institution in the world); Ronnie Flynn (former president of the Southern Baptist Convention); Ralph Reed (founder of "The Faith and Freedom Coalition"); Tony Suarez (executive vice president of "The National Hispanic Christian Leadership Conference"), and Michelle Bachmann (retired Congresswoman). ${ }^{143}$ Trump also regularly posed for pictures, while prominent evangelical pastors laid their hands on him to pray for God's blessing on his campaign.

Jerry Falwell, Jr., whose father had founded the "Moral Majority" in 1979, was one of the very first evangelical leaders to endorse Trump during the Republican primaries (in January of 2016). While acknowledging that there were more devout (and

\footnotetext{
${ }^{141}$ Women in the World, "Hillary Clinton's Keynote Address at the 2015 Women in the World Summit," April 23, 2015, video, 23:12. https://www.youtube.com/watch?v=pVTiAJ1e9SM

${ }^{142}$ CBS News, "Hillary Clinton Says Half of Trump's Supporters Are in a "Basket of Deplorables," September 10, 2016. https://www.youtube.com/watch?v=PCHJVE9trSM (accessed February 28, 2020).

${ }^{143}$ Emma Green, "Trump is Surrounding Himself with Evangelical Pastors," June 21, 2016. https://amp.theatlantic.com/amp/article/488114/ (18 February 2020).
} 
even openly evangelical) GOP candidates in the running, Falwell said that he was convinced that Trump alone had the requisite political skill to win the general election. ${ }^{144}$ When confronted by critics about Trump's character and comportment, which had so often seemed out of sync with evangelical ideals, Falwell replied: "We're not electing a pastor in chief. When you have a sick child, you look for the best doctor for that child. You don't look for the doctor that shares your faith or theology. That's what I think we have to do with government. We have to find the candidate who is most likely to support all the values that we hold dear." ${ }^{\text {"145 }}$ Falwell also lamented that "it was just as tough a sell with evangelicals to get them to vote for somebody like Ronald Reagan, who'd been married twice, as it was ... to get them to support Trump. It was the same dynamic. It was like history repeated itself .... [However,] we need somebody tough. We need somebody who has the right positions on the issues." ${ }^{146}$

Falwell also affirmed that "politics is a blood sport," and although "[Trump] might be a little brash, ... we need a president who is willing to fight our enemies, ... to not be afraid, to not back down." ${ }^{147}$ Falwell stated that Trump was "not so concerned about rehearsing and focus-grouping every statement he makes .... He could be more

\footnotetext{
${ }^{144}$ ABC News, “Jerry Falwell Jr. on President Trump: He 'Doesn't Say What's Politically Correct,"” August 20, 2017, video, 10:54. https://www.youtube.com/watch?v=_2QqAZydbTE

${ }^{145}$ Fox News, "Jerry Falwell Jr. on Evangelicals' Role in Trump's Election,” December 25, 2016, video, 10:48. https://www.youtube.com/watch?v=jzAzeTCcrtQ

${ }^{146}$ Retro Report, "The Roots.”

${ }^{147}$ CNN, "Falwell Jr. on Trump: We're Not Electing a Pastor-in-Chief," June 1, 2016, video, 9:45. https://www.youtube.com/watch? $\mathrm{v}=\mathrm{G} 42$ VEGGmliQ
} 
polished ... [but] he's bold. And I admire that in a leader."148 And Falwell bluntly tweeted that 'conservatives \& Christians need to stop electing 'nice guys.' They might make great Christian leaders, but the United States needs street fighters like [Trump] at every level of government, b/c [sic] the liberal fascists Dems are playing for keeps \& many [Republican] leaders are a bunch of wimps!"149

Falwell opined that in the 2016 presidential election, "the key issues are security and the economy .... Maybe next time we can choose a president, who can help with social issues." ${ }^{150}$ And when asked about Trump's alleged sexual indiscretions with porn star, Stormy Daniels, Falwell called for clemency, stating that "our whole faith is based on the theology of forgiveness .... We're all equally bad."'151

Trump requited Falwell by delivering his first commencement address as president at Liberty University, an honor that past commanders in chief had traditionally reserved for Notre Dame. ${ }^{152}$ And to this day, Falwell is still routinely recommended to news outlets, as a spokesperson for the White House, on matters pertaining to faith. ${ }^{153}$

\footnotetext{
148 ABC News. "Jerry Falwell Jr. on President Trump."

149 Jerry Falwell, Twitter Post, September 28, 2018. https://twitter.com/JerryFalwellJr/status/1045853333007798272?ref_src=twsrc\%5Etfw\%7Ctwcamp $\% 5 \mathrm{Etw}$ eetembed $\% 7 C$ twterm $\% 5 \mathrm{E} 1045853333007798272$ \&ref_url=https\%3A\%2F\%2Fthehill.com $\% 2 \mathrm{Fblogs} \% 2 \mathrm{Fbl}$ og-briefing-room\%2F409151-jerry-falwell-jr-conservatives-and-christians-need-to-stop-electing

${ }^{150}$ CNN, "Falwell Jr. on Trump."

${ }^{151}$ CNN, “Jerry Falwell Jr.: Evangelicals Forgive Trump,” January 25, 2018, video, 5:19. https://www.youtube.com/watch?v=vzJ6Ou8ZUKs

152 Fox News, “Jerry Falwell Jr. on President Trump's Commencement Speech,” May 13, 2017, video, 7:01. https://www.youtube.com/watch?v=K7d3ZjwHRrc
}

153 ABC News, "Jerry Falwell Jr. on President Trump." 
Another extrusive Trump apologist was Robert Jeffress (pastor of the First Baptist Church of Dallas, Texas), who was likely Trump's earliest eminent evangelical advocate. All the way back in September of 2015, he wrote,

No evangelical I know is expecting Trump to lead our nation in a spiritual revival. But seven years of Barack Obama have drastically lowered the threshold of spiritual expectations evangelicals have of their president. No longer do they require their president to be one of them. Evangelicals will settle for someone who doesn't HATE [emphasis his] them, like the current occupant of the Oval Office appears to. ${ }^{154}$

And on July 1, 2017, during the "Celebrate Freedom Concert” at Washington D.C.'s Kennedy Center, Jeffress declared that he was "grateful that President Trump has created an atmosphere in which Evangelical Christians feel at home once again in our nation's capital.”155 The Texas minister likewise defended Trump against accusations of consistent, unchristian-like speech, by stating that "government is to be a strong man, to protect its citizens in defense against evil doers. When I'm looking for somebody who's going to deal with Isis, ... I don't care about that candidate's tone or vocabulary, I want the meanest, toughest, son of a you-know-what I can find. And I believe that's biblical."156

On a similar note, Michael Graham (evangelical columnist for the Boston Herald), explained that many members of his community had "hired" Trump as a

\footnotetext{
${ }^{154}$ Robert Jeffress, "Why Trump is Triumphant with Evangelicals . . For Now," Fox News. September 8, 2015. https://www.foxnews.com/opinion/why-trump-is-triumphant-with-evangelicals-for-now (accessed February 18, 2020).

${ }^{155}$ Rebecca Barrett-Fox, "King Cyrus President," 502.

156 The Mike Gallagher Show, “Dr. @RobertJeffress and @Peter Wehner Join Mike for an Important Debate over Evangelical Christian Support of Trump,” The Mike Gallagher Show, July 12, 2016. https:/www.mikeonline.com/dr-robertjeffress-peter_wehner-join-mike-for-an-important-debate-overevangelical-christians-support-of-trump
} 
political "hit-man" or "bouncer," to "clean up" Washington D.C. Graham stated sardonically, “you don't mind if he gets his knuckles bloody, because he's there to fight for you." ${ }^{157}$ Lance Wallnau (evangelical evangelist and author) claimed that the Lord also disclosed to him in a prophetic word, that Trump was a "wrecking ball to the spirit of political correctness." 158 And he certainly has relentlessly attacked the mainstream ("fake news") liberal media, which most evangelicals believed had marginalized, demonized and victimized them for decades. The ancient proverb seems applicable on this point: the enemy of my enemy is my friend.

Critics have habitually charged evangelicals with endorsing Trump due to their unbridled lust for power, because they saw him as their "fixer." ${ }^{159}$ But in March of 2018, Franklin Graham (evangelist and son of Billy Graham), avowed that the ideology of historic Christian nationalism was, for all intents and purposes, dead within his movement. Graham declared, "the message from the church community now is not, you have to do it our way. The days of trying to ban things or boycott things are over. [Evangelicals] just want to be left alone to practice their faith. And they feel like the government won't allow them to. And Donald Trump was the barrier - the guy who stepped up to create some space for them and defend their freedom." 160

\footnotetext{
${ }^{157}$ CBS News, "Why Evangelical Christians."

${ }^{158}$ Lance Wallnau, "Why I Believe Trump Is the Prophesied President," Charisma News. October 5, 2016. https://www.charismanews.com/politics/opinion/60378-why-i-believe-trump-is-the-prophesied-president (accessed February 28, 2020).

159 Jennifer Bardi, "King of This World: Irreligious Trump Remains Popular with Evangelicals," The Humanist (November-December, 2019): 8.

${ }^{160}$ CBS News, "Why Evangelical Christians."
} 
Notwithstanding, that wasn't the platform on which Trump had run. He pledged in a 2016 Iowa rally, 'I'll tell you one thing: I get elected president, . . . Christianity will have power . . . . Because if I'm there, you're going to have plenty of power. You don't need anybody else. You're going to have somebody representing you very, very well. Remember that."161

And Trump repaid his evangelical supporters with a cornucopia of elite positions within his administration. Most notably, there was his Vice-Presidential running-mate, Mike Pence (an evangelical Catholic), who had frequently affirmed, "I'm a Christian, a conservative and Republican —in that order." Trump also eventually appointed numerous outspoken evangelicals to his cabinet, including “Attorney General Jeff Sessions;

Housing and Urban Development Secretary Ben Carson; CIA director Mike Pompeo; EPA chief Scott Pruitt; . . . Energy Secretary Rick Perry; Education Secretary Betsy DeVos; Agriculture Secretary Sunny Perdue; [along with] US Ambassador to the United Nations Nikki Haley.""162 And Trump has regularly leaned on his "Faith Advisory Council" of evangelicals, remaining uncommonly responsive to their concerns. ${ }^{163}$ Presidents seldom make new friends in office, so they need to hang on tightly to their old ones.

\footnotetext{
${ }^{161}$ Rebecca Barrett-Fox, "King Cyrus President," 515.

${ }^{162}$ Dave Brody, et al., The Faith of Donald Trump,261.

${ }^{163}$ Nina Burleigh, "Evangelical Christians Helped Elect Donald Trump, but Their Time as a Major Political Force Is Coming to an End; Republicans Relied on Evangelicals for Decades, but a Political Reckoning is Afoot." Newsweek. December 21, 2018. https://www.newsweek.com/2018/12/21/evangelicals-republicanstrump-millenials-1255745.html (accessed March 25, 2020).
} 


\section{Rebecca Barret-Foxx (professor of sociology at Arkansas State University),} astutely stated that Trump's "lack of faith protects him from charges of hypocrisy .... Viewing Trump as an outsider to the religious right's moral community, inhibits negative feelings, such as moral disgust, indignation, and even contempt, that might otherwise undermine acceptance of him." ${ }^{, 164}$ And Frances FitzGerald (best-selling political author) perceptively added that since Trump made no pretense of practicing religion, "he had to do more for [evangelicals] than anyone else" to earn their trust. ${ }^{165}$ And on that point, most of his evangelical supporters appeared to believe that he had substantially delivered.

\section{Evangelical Policies}

Trump promised to champion six key policies, which his evangelical supporters had prioritized. These policies were the nomination of conservative judges; the protection of religious liberty; the promotion of Israel's welfare; the advancement of the pro-life agenda; the effective enforcement of immigration law; and the perpetuation of Republican, fiscal conservativism. ${ }^{166}$

\footnotetext{
${ }^{164}$ Rebecca Barrett-Fox, "King Cyrus President," 514.

${ }^{165}$ American Academy in Berlin. "Frances FitzGerald: Evangelicals and Trump's Republican Party". November 8, 2018, video, 1:22:16. https://www.youtube.com/watch?v=xJ2tGPeq6Do

${ }^{166}$ In his 2016 address to the Republican National Convention, when its delegates nominated Trump, Jerry Falwell Jr. highlighted four key issues of concern, which Trump had promised to address: the repeal of the Johnson amendment; the curtailing of unfair investigations into evangelical churches and schools; the protection of Israel, including the opposing of Iran; and the appointment of justices to the Supreme Court, who would support conservative (especially pro-life) causes. See Jerry Falwell, Jr., "Jerry Falwell Jr., President of Liberty University, Speaks at the Republican National Convention July 21, 2016," July 21, 2016, video, 7:01. https://www.youtube.com/watch? $\mathrm{v}=5 \mathrm{YcOz} 2 \mathrm{~J} 7 \mathrm{vuE}$
} 
The Nomination of Conservative Judges

Trump vowed to nominate judges who were ideologically conservative, even publishing a list of potential appointees during the campaign, which was enthusiastically applauded by the evangelical and broader conservative communities. In recent decades, these groups had unceasingly bemoaned what they claimed was the pilfered power that the Supreme Court had garnered to itself, while stymying the founding fathers' objective to preserve the judiciary as government's weakest branch. Despite the Constitution, progressives had circumvented Congress to advance their agenda, in favor of "legislating from the bench," thus turning SCOTUS into America's premier ideological battlefield.

So, during his first presidential term, Trump spearheaded the installment of two conservative justices on the Supreme Court, Neil Gorsuch (2017) and Brett Kavanaugh (2018). In addition, nearly two hundred of his judicial nominees to lower U.S. Courts, have already been confirmed by the Senate. That is arguably the most impressive presidential record in American history. ${ }^{167}$ And many conservatives believe that this will be Trump's most important and lasting legacy.

\section{The Protection of Religious Liberty}

Prior to his election, Trump pledged to be a stalwart guardian of religious liberty for evangelicals. And on May 4, 2017 (the annual national "Day of Prayer"), the president signed an executive order entitled, "Promoting Free Speech and Religious

\footnotetext{
${ }^{167}$ Fred Lucas, "Fact Check: Does Trump Have the Most Successful Judicial Nomination Record Since George Washington?," The Daily Signal. July 26, 2019. https:/www.dailysignal.com/2019/07/26/factcheck-does-trump-have-the-most-successful-judicial-nomination-record-since-george-washington (accessed March 3, 2020).
} 
Liberty," which primarily targeted the 1954 Johnson amendment. Specifically, this EO "instructed the Department of Treasury and the IRS not to take adverse action against churches and 501(c)(3) nonprofits that speak out about moral and political issues in accordance with their faith .... [It] also called on the Department of Justice to issue guidance to federal agencies about how they can best protect religious liberty as it applies under federal law." 168

Perhaps most notably, this order took initial steps to safeguard religious organizations which, based on their faith-teachings, did not permit their employees, students and other circumscribed affiliates, to promote or engage in homosexual practices. ${ }^{169}$ Nearly all self-identifying evangelicals, believe that the Bible identified same-sex attraction as a temptation (rather than a God-given orientation), which must be resisted with His help (see Genesis 19:5; Leviticus 18:22; 20:13; Deuteronomy 23:17; Judges 19:22; Romans 1:26-27; 1 Corinthians 6:9; 1 Timothy 1:10; and Jude 1:7). Furthermore, Trump's order relaxed the requirement in Obama's Affordable Care Act, that employers provide birth control (some of which was abortifacient), as part of their employee health insurance plans (viz., carving out exceptions on religious grounds). ${ }^{170}$

\footnotetext{
${ }^{168}$ Samuel Smith, "7 Accomplishments That Evangelicals Like," The Christian Post. December 15, 2017. https://www.christianpost.com/news/7-trump-accomplishments-evangelicals-like.html?page=3 (accessed February 24, 2020).

${ }^{169}$ Pete Baklinski, "Trump Signs Order Protecting Freedom for Opponents of Abortion, Gay 'Marriage," May 4, 2017. https://www.lifesitenews.com/news/breaking-trump-signs-order-protecting-freedom-foropponents-of-abortion-gay (accessed February 24, 2020).

${ }^{170}$ Brianna Ehley, “Trump Rolls Back Obamacare Birth Control Mandate,” Politico. October 6, 2017. https://www.politico.com/story/2017/10/06/trump-rolls-back-obamacares-contraception-rule-243537 (accessed February 24, 2020).
} 
In February of 2017, Trump also rescinded Obama's directive to public schools, that transgender students should be granted access to the (male or female) bathroom of their choice, while on campus. In March of 2017, the president revoked an Obama executive order, which "prevented federal contracts from being awarded to businesses, faith-based companies and nonprofits, that have hiring practices that critics say discriminate on the basis of sexual orientation and gender identity." ${ }^{171}$ On September 5, 2017, Attorney General, Jeff Sessions, issued a firm "directive" to all federal agencies to respect the religious liberty of any "sincerely-held" belief of religious people (including government workers), based on the "free exercise clause." And in January of 2018, Trump founded the "Conscience and Religious Freedom Division" of the Department of Health and Human Services, primarily to safeguard doctors from being forced to provide medical services, which conflicted with their convictions of conscience. ${ }^{172}$

Gerardo Marti (chairmen of the sociology department at Davidson College) perspicaciously observed that religious groups typically deduced the "orthodoxy of an actor," based on his or her "support [of] . . religiously defined group interests," rather than "statements of belief or piety of behavior." Marti asseverated that to these groups, it is "not what you believe but what you fight for" that matters most. ${ }^{173}$

And Franklin Graham seemed to agree. In a 2018 HBO interview, the outspoken evangelist clarified: "I never said [Trump] was the best example of the Christian faith. He

\footnotetext{
${ }^{171}$ Samuel Smith, "7 Accomplishments."

${ }^{172}$ Noah Weiland, "Evangelicals, Having Backed Trump, Find White House Front Door Open," Philadelphia Tribune (March 30, 2018): 9B.

${ }^{173}$ Gerardo Marti, "The Unexpected Orthodoxy,” 4.
} 
defends the faith." ${ }^{174}$ And evangelicals believed that the gospel was the only hope of the world. The apostle Paul exhorted believers in all cultures, throughout history, to pray continually that civil authorities grant them the freedom to live "quiet and peaceable" lives (1 Timothy 2:1-2), so "the word of the Lord [could] run swiftly, and be glorified" (2 Thessalonians 3:1b); meaning that Christ's followers would never be hindered in any way, from spreading and authentically living out their faith. In many evangelicals' minds, Trump was God's unlikely instrument in answering their prayers.

On a more symbolic note, Trump declared September 3, 2017 to be an additional, unofficial "National Day of Prayer," for the victims of Hurricane Harvey. ${ }^{175}$ And he has frequently encouraged American citizens to honor the traditional practice of saying, "Merry Christmas" in December, instead of offering more religiously neutral forms of well-wishing like "Season's Greetings" or "Happy Holidays.” In that regard, he pledged to sign off all of his personal year-end White House correspondence, with the cherished phrase, "Merry Christmas."176 Though these gestures were not legislatively substantive, they did plainly underscore Trump's deference toward Christians; thus perhaps giving pause to progressives, who might otherwise seek to more aggressively advance an antievangelical agenda.

\footnotetext{
${ }^{174}$ N.A., "Franklin Graham: Trump 'Defends the Faith,”' Axios. November 26, 2018. https://www.axios.com/franklin-graham-donald-trump-6b18159f-d481-48e2-9eb3-ea48f4eb26aa.html. (accessed February 27, 2020).

${ }^{175}$ Noah Weiland, "Evangelicals, Having Backed," 9B.

${ }^{176}$ Nathan Guttman, "Evangelicals Hail Trump's Policy Moves,” Forward (February 17, 2017): 3. Accessed from ProQuest, February 27, 2020.
} 
The Promotion of Israel's Welfare

Upon taking office, Trump vowed to be a steadfast ally of Israel, which many evangelicals believed was a principal linchpin to sustaining God's blessing on America. In Genesis 12:3a, the Lord covenanted with Abraham (and many believed by extension, all Hebrew people throughout history), "I will bless those who bless you, and I will curse him who curses you ...." This promise (or a close equivalent) was reiterated in a legion of passages throughout the Old and New Testaments (including Genesis 18:18; 22:18; 26:4; 27:29; Exodus 23:22; Numbers 24:9; Psalm 72:17; Acts 3:25; Romans 9-11; and Galatians 3:8). Therefore, many Christians have concluded that Yahweh's commitment to bless or curse nations and individuals, based on how they conducted themselves toward Israel, was unconditional (see Genesis 15:12-21). And this divine contract would be supernaturally enforced until the end of the Age. ${ }^{177}$

Consequently, many evangelicals were elated in December of 2017, when Trump announced the relocation of the U.S. embassy in Israel to Jerusalem (from Tel Aviv). Scripture declared that God Himself had ordained Jerusalem as Israel's capital in biblical times (see 2 Samuel 5:7, 9; 1 Kings 8:1; Psalm 53:6; 147:7; 69:35; and Isaiah 28:16; 51:11). And the Apostle John forecasted that the "holy city" would be reinstated to that position again, prior to Christ's Second Coming (see Revelation 11:2; 21:2, 10; 22:19). ${ }^{178}$ American presidents had been promising to enforce the 1995 U.S. law that mandated this move for decades. But up until Trump, each one had signed a new

\footnotetext{
${ }^{177}$ Russel Moore, "From the House of Jacob to the Iowa Caucuses: The Future of Israel in Contemporary Evangelical Political Ethics," Southern Baptist Journal of Theology 11 (Winter 2017): 15.

${ }^{178}$ John Fea, Believe Me, 143-145.
} 
temporary waiver every six months, to avoid outcries from the international community. In fact, 128 countries voted for a U.N. resolution, declaring Israel's decision to move its capital to Jerusalem as "null and void." However, Trump got it done (in May of 2018); thus, signaling to the world his unflinching commitment to stand fast (alone if need be) with the "chosen" people of God.

In March of 2018, Trump signed the Taylor Force Act, which cut foreign aid to the Palestinian authority, for refusing to crack down on terrorism against Israel. In June of 2018, Trump withdrew from the U.N. Human Rights Council, principally due to its perceived anti-Semitic practices. In March of 2019, he recognized Israel's sovereignty over the Golan Heights, as well as their unqualified right to defend their territories. And in December of 2019, Trump declared, at the Israeli American Council's national summit: "The United States-Israeli relationship is stronger now than ever before .... The Jewish state has never had a better friend in the White House than ... Donald Trump." 179

Perhaps of paramount importance, was Trump's firm and forceful stand against Israel's most powerful and strategic enemy in the Middle East—Iran. In May of 2018, he backed out of Obama's 2015 nuclear deal, subsequently crippling Iran's economy through renewed sanctions, to coerce abandonment of their nuclear weapons development program. And in a display of utmost resolve to the Iranian government, in January of 2020, Trump ordered the assassination of Qasem Soleimani (one of the

\footnotetext{
179 The White House, "President Trump Delivers Remarks at the Israeli American Council National Summit 2019," December 8, 2020, video, 58:45. https://www.youtube.com/watch?v=7YlonD037SQ\&t=1652s
} 
nation's highest-ranking generals) for "terrorist" activities. In so many ways, in both word and deed, Trump has "blessed" Israel and "cursed" her enemies, enabling his evangelical base to rest much easier about the future.

The Advancement of the Pro-life Agenda

Trump promised that upon assuming office, he would pursue an aggressive prolife agenda. Nearly all professing evangelicals believed that the Bible taught that life began at conception; therefore, abortion was immoral in the eyes of God, except in extreme situations where there was a significant threat to the life or health of the mother (see Exodus 21:22-25; Judges 13:5; Job 31:15; Psalm 51:5; 71:6; and Luke 1:15, 44). ${ }^{180}$ Trump had a lot to prove to evangelicals in this regard, since he had publicly espoused a pro-choice position in 1999, which he reversed just before announcing his presidential run in 2015. And he has delivered once again.

In addition to the pro-life accomplishments already noted above, in January of 2017, Trump reinstated and exponentially expanded the GOP's standard "Mexico City Policy," withholding $\$ 8.8$ billion in foreign aid to inter-governmental organizations that encouraged (or assisted clients with) abortions. ${ }^{181}$ In April of 2017, he halted contributions to the "United Nations Fund for Population Activities," which assisted with state-mandated abortions in authoritarian regimes. Also, the president initiated the cutting of billions of dollars in federal and state funding to Planned Parenthood: by signing two

\footnotetext{
${ }^{180}$ Russel Moore, “The Gospel According,” 43.

${ }^{181}$ Nathan Guttman. "Evangelicals Hail," 3.
} 
landmark bills to that effect (in April of 2017 and February of 2019) and by rescinding related executive "guidance," issued during the Obama administration (in January of 2018). In June of 2019, he compelled health insurance providers to more plainly delineate whether or not their policies covered abortions. And he canceled existing federal contracts for research testing on aborted fetuses. In January of 2020, he increased individual state latitude in allocating their federal funding to pursue abortion alternatives. That same month, he signaled that there would be a substantial coming crackdown on states that discriminated against faith-based organizations, which did not provide employee health coverage for abortion. ${ }^{182}$ And finally, on January 24, 2020, Trump became the first president ever to speak live at the "Right to Life" rally in Washington D.C.

\section{The Effective Enforcement of Immigration Law}

Right out of the gate, Trump established that cracking down on illegal immigration would be a centerpiece of his 2016 campaign, so that he could "restore the rule of law and secure [the American] border." ${ }^{183}$ And the official White House website registered five related objectives, which Trump has been hawkishly pursuing ever since, including "constructing a border wall;", "ensuring the swift removal of unlawful

\footnotetext{
${ }^{182}$ N.A. "President Trump's Pro-life Wins." Susan B. Anthony List. N.D. https://www.sba-list.org/trump-pro-life-wins (accessed March 5, 2020).

${ }^{183}$ N.A. "Immigration.” The White House. N.D. https://www.whitehouse.gov/issues/immigration (accessed March 5, 2020).
} 
entrants;" "ending chain migration;" "eliminating the Visa Lottery;" and "moving the country to a merit-based entry system."184

This website is continually updated to maintain an exhaustive list of Trump's related accomplishments and contains hundreds of pertinent press-releases. For example, during his first month in office (January of 2017), the president signed four relevant executive orders: temporarily barring migrants from select countries that were deemed to be terrorist havens; stripping sanctuary jurisdictions of federal funding; authorizing the building of a wall on the Mexican border; and curtailing the number of guest workers allowed to enter the country. Throughout his subsequent term in office, Trump has furthermore: strongly encouraged government agencies to employ Americans, instead of lower-paid foreign workers; regularly deployed U.S. troops to secure the southern border; increased funding to hire additional border security agents and immigration judges; reduced the total number of legal immigrants to the U.S. (by about 7 percent since 2016); and made notable progress on constructing the southern border wall. ${ }^{185}$

Though his opponents disputed the full extent to which Trump's policies had effectively enforced immigration law, it is difficult to deny that no Republican president in recent times, has worked harder or accomplished more in this endeavor. And Trump did so against fierce resistance, not only from Democrats, but from virtually the entire

\footnotetext{
${ }^{184}$ Ibid.

${ }^{185}$ N.A. "Trump Administration Immigration Accomplishments." The Federation for American Immigration Reform, 2020. https://www.fairus.org/issue/presidential-administration/trump-administrationimmigration-accomplishments (accessed March 6, 2020). On November 4, 2019, Rodney Scott (chief of Customs and Border Protection) claimed that 78 miles of the southern border wall have already been constructed; 158 miles are being constructed; and 273 miles are in pre-construction. See Rodney Scott, Twitter Post, November 4, 2019. https://twitter.com/USBPChief/status/1191337312363438080
} 
political and financial establishments, as well as a significant percentage of American citizens. $^{186}$

Evangelicals who supported Trump, adamantly disclaimed allegations that his (and their) desire to effectively enforce immigration law was, in truth, rooted in racist, xenophobic and Islamophobic proclivities. Instead, they insisted that this clampdown was impelled by political, safety, and financial concerns. And they blamed obstructionist, Democratic lawmakers for the undesirable consequences that ensued, as Trump pursued this just agenda.

In February of 2015, Pat Robertson posited that Democratic enthusiasm for mass immigration from South America was driven, not by compassion, but by a naked lust for political power, stating,

We've got to remember what the game is. If 5-10 million undocumented workers suddenly appear on the voting roles, it is thought they will vote overwhelmingly Democrat .... And it will change the electoral politics in America, maybe for the rest of our life .... So [these people] can't speak English? — too bad. So, they can't hold a job? - tough luck .... We're going to give them health care. We're going to give them a free education if they want it. But more than anything, we're going to sign them up as Democrats. ${ }^{187}$

In November of 2015, Trump seemed to suggest that he would implement a mandatory "registry" for all Islamic immigrants. ${ }^{188}$ And the next month, he tendentiously called for a "total and complete shutdown of Muslims entering the United States, until

\footnotetext{
186 Pew Research Center, "How Americans See Illegal Immigration, the Border Wall and Political Compromise," January 16, 2019. https://www.pewresearch.org/fact-tank/2019/01/16/how-americans-seeillegal-immigration-the-border-wall-and-political-compromise (accessed March 5, 2020).

${ }^{187}$ Secular Talk, "Pat Robertson Rips Immigrants—Like Jesus,” February 24, 2015, video, 8:26. https://www.youtube.com/watch?v=fAO5b7ITtHo

${ }^{188}$ MSNBC, "Donald Trump: 'I Would Certainly Implement' Database For Muslims," November 15, 2015, video, 1:23. https://www.youtube.com/watch?v=8Q4SDWMnjak
} 
our country's representatives can figure out what the hell is going on!"189 This echoed the following, strikingly similar proposal, submitted by Franklin Graham almost six months earlier (on his personal Facebook page): "We are under attack by Muslims at home and abroad. We should stop all immigration of Muslims to the U.S. until this threat with Islam has been settled. Every Muslim that comes into this country has the potential to be radicalized—and they do their killing to honor their religion and Muhammad."190

Additionally, in January of 2017, Graham told the Huffington Post: "It's not a biblical command for the country to let everyone in who wants to come .... We want to love people [and] we want to be kind to people, ... [but] there are laws that relate to immigration and I think we should follow those laws .... We need to know who [these immigrants] are and what they believe, if they share the same core values of freedom and liberty."191

Graham also parried off blame from Trump for migrant families being separated at the border; placing it instead on lawmakers "over generations ignoring" established enforcement statutes. ${ }^{192}$ Furthermore, he advised that U.S. tax dollars would be better

\footnotetext{
189 ITV News, “Donald Trump Vows to Ban Muslims Entering US,” December 7, 2015, video, 0:30. https://www.youtube.com/watch?v=viDffWUjcBA

${ }^{190}$ Franklin Graham, Facebook Post, July 15, 2015.

https://www.facebook.com/FranklinGraham/posts/967305353325646

${ }^{191}$ Carol Kuruvilla, “Here's How Franklin Graham Justifies Trump's Expected Refugee Ban,” Huffington Post. January 25, 2017. https://www.huffpost.com/entry/frankling-grahamrefugees_n_5889049ce4b061cf898c6c42 (accessed March 5, 2020).

192 CBN News, “'It's Disgraceful:' Franklin Graham Rebukes Immigration Policy on CBN Drawing National Attention,” June 14, 2018, video, 0:50. https://www.youtube.com/watch?v=bmpX11JONrI
} 
spent on creating "safe zones" for refugees in their native (or neighboring) countries, instead of granting them asylum in America. ${ }^{193}$

In January of 2017, Robert Jeffress also propounded, that in light of the threat of radical Islamists, it was not unconstitutional to instate a "religious test" for anyone seeking to immigrate to America. ${ }^{194}$ Then in January of 2018, he repudiated the notion of an "open borders" policy, insisting instead that immigration must be "merit-based." $\mathrm{He}$ expounded that "there are so many sincere Christians out there who ... don't understand the difference between the responsibility of the church in showing mercy and inviting everybody, and the responsibility that God [has] given government to protect our nation," especially from terrorism. ${ }^{195}$

In July of 2019, James Dobson wrote in a support letter that he also wanted the American border "closed to those who attempt to enter illegally." 196 He likewise criticized the "liberal Congress and judges," along with the Obama administration, which had previously instituted America’s “unworkable” immigration policies. And he repeated the accusation that "Democrats want massive numbers of immigrants who will someday become voters." In addition, Dobson lamented that because border patrol agents had to

\footnotetext{
${ }^{193}$ CBN News, "Franklin Graham on Islam, Immigration, P. Parenthood," Oct 9, 2015, video, 6:33. https://www.youtube.com/watch?v=sb32FrYqPRA

194 Fox Business, “Why Religion Doesn't Play a Factor in Trump's Immigration Order,” February 10, 2017, video, 2:44. https://www.youtube.com/watch?v=5eO58kabN98

195 Fox Business, “America Needs Merit-based Immigration System: Pastor Jeffress,” January 12, 2018, video, 4:07. https://www.youtube.com/watch?v=JbxoNOR3u_Y

196 James Dobson, “Dr. Dobson's July Newsletter,” Dr. James Dobson’s Family Talk. July 2019. https:/www.drjamesdobson.org/news/commentaries/archives/2019-newsletters/july-newsletter-2019 (accessed March 5, 2020).
} 
devote so much effort to apprehending those entering from Mexico illegally, they weren't as effective at halting the smuggling in of illegal drugs, which were decimating the lives of American youth. Dobson's letter was laced with empathy for all these desperate people, who were fleeing from oppression as refugees, or simply hoping for a better life for their families. However, he warned that,

many of them have no marketable skills. They are illiterate and unhealthy. ... [And] their numbers will soon overwhelm the culture as we have known it, and it could bankrupt the nation. America has been a wonderfully generous and caring country since its founding. That is our Christian nature. But in this instance, we have met a worldwide wave of poverty that will take us down if we don't deal with it. And it won't take long for the inevitable consequences to happen. ${ }^{197}$

From a biblical standpoint, it is important to note (especially in light of the forthcoming discussion in chapter four of this thesis) that Old Testament Israel maintained an "open borders" policy, and God commanded the Jewish people to enthusiastically welcome all immigrants (see Exodus 23:9; 22:21; Deuteronomy 10:19; 24:14, 17; 27:19; Psalm 94:6; Ezekiel 22:7; and Malachi 3:5). However, each migrant had to submit to the entire Mosaic law, which embodied one of the most rigorous societal codes in history (including monotheistic worship, Sabbath observance, ritual cleanness requirements, sacrificial offerings, civil regulations, and sexual practices). And these statutes were to be impartially enforced (based on the wrongdoer's degree of contrition and/or the severity of offense) through fines (Exodus 12:35-36; Numbers 5:6-7); beatings (Deuteronomy 25:3); maiming (Exodus 21:24-25); expulsion from society (Leviticus 7:27; 18:29; 23:29); and execution (Exodus 21:12; 35:16-17; Deuteronomy 19:11-12). Also, although the Hebrew law prescribed atypical provisions to champion commonly

${ }^{197}$ Ibid. 
marginalized societal groups (including women, children, the poor and immigrants), there were no state entitlement programs to galvanize mass migration, comparable to those which are currently accessible in the United States. Therefore, unless one truly yearned to follow Yahweh, there was a potent incentive to self-deport.

\section{The Perpetuation of Republican, Fiscal Conservatism}

Evangelicals tended to identify as political conservatives. So, it should have come as no surprise that the lion's share of them would back whatever presidential candidate the Republican party nominated, because he or she was likely to be more ideologically conservative than any Democratic challenger. In 2016, evangelical support for Trump (at 81 percent) was only slightly higher than it had been in 2012 for Mitt Romney (at 78 percent); in 2008 for John McCain (at 74 percent); and in 2004 for G.W. Bush (at 78 percent). ${ }^{198}$ And perhaps the chief catalyst for many evangelicals voting for Trump, was their desire to block Hillary Clinton from the Oval Office, where she could enact a leftwing agenda that ran completely cross-grain to conventional sensibilities.

Fundamentally speaking, most political conservatives generally seek to "conserve" things the way they are, retaining existing power structures (especially most financial ones), which in America, have historically favored white Christians. ${ }^{199}$ On the other hand, progressives typically seek to "progress" (as they see it) beyond the past, by

\footnotetext{
${ }^{198}$ Fox News,. “Jerry Falwell Jr. on Evangelicals' Role in Trump's Election,” December 25, 2016, video, 10:48. https://www.youtube.com/watch?v=jzAzeTCcrtQ

${ }^{199}$ It is important to note that many conservatives and libertarians favor a more free-market approach to finance, because they believe that it serves as a vital impetus for innovation. So, they are not as interested in preserving all existing financial structures. While conservatives who were most enthusiastic about Trump, tended to prefer a more protectionist approach.
} 
remedying the systemic, institutional oppression of traditionally marginalized societal groups (which most notably include people of color, immigrants, the poor, and members of the LGBT community). Naturally, progressives generally want a more powerful government to help level the playing field, in pursuit of fairness, while conservatives favor a more limited government, to restrain change.

This ideological distinction is perhaps most palpable, in respect to fiscal policy. And evangelicals customarily regarded the long-established economic platform of the Republican Party (which Trump led), as more accurately harmonizing with the principles and precedents that Scripture outlined. The two most relevant examples to this study (which will be examined below) are modest taxation and stringent requirements for receiving government welfare. Although these issues were not extensively addressed by evangelicals who supported Trump, they were central to the critique of evangelicals who opposed him (which will be examined in chapter four). Therefore, this section will equip the reader with an adequately nuanced explication of biblical teaching regarding state fiscal policy. ${ }^{200}$

First, the fiscal conservativism of the Republican Party (which Trump led) favored modest taxation, to allow Americans to keep more of what they earned and limit government power. Correspondingly, Moses' law laid out a modest (“flat") taxation plan for Israel's theocracy, where each citizen paid just 13.33 percent of their annual income: 10 percent went to support the priestly tribe of Levi; and 3.33 percent was appropriated

\footnotetext{
200 Throughout Trump's first presidential term, he and his fellow Republicans did advocate for legislation that conformed to their party's historic, fiscal conservativism. However, during the covid-19 pandemic, they were forced by the dire circumstances that ensued, to support a $\$ 2$ trillion-dollar stimulus package in March of 2020, to assist with the fiscal needs of American institutions, businesses and individual citizens.
} 
by temple magistrates to fund all government expenditures, including providing for certifiably destitute Hebrew citizens (see Leviticus 27:30-32 and Deuteronomy 14:28-29; 16:16). About 400 years later, the Israelites obstinately demanded a king, despite divine warnings that a monarch would levy heavy taxation upon them, to fund a superfluous and bloated central government. In the end, the Lord reluctantly granted their request, but this is typically deemed to be the "permissive," rather than "perfect" will of God (1 Samuel 8:10-22; see also Romans 12:2). New Testament authors did not address state taxation policy per se, other than to exhort Christians to comply with Caesar's dictums (see Matthew 22:21; Mark 12:17; Luke 20:25; and Romans 13:7-8).

The extensive review of evangelical works conducted for this study did not unearth any relevant and important discussion among the most prominent evangelical supporters of Trump, regarding modest taxation. Their relative silence on this issue may reflect their predilection, as religious leaders, not to appear preoccupied with pecuniary concerns. Also, this has never been a major point of emphasis for most evangelical church leaders, whose apprehensions of Biblical teaching on this subject differ appreciably (which will be discussed further in chapter four of this thesis).

Second, the fiscal conservatism of the Republican Party (which Trump led) historically favored stringent requirements for receiving government welfare. Likewise, the Old Testament law made ample provision for the poor to procure food, providing they consented to work physically to harvest it (see Leviticus 19:9-10; Numbers 18:21-28; Deuteronomy 24:19-22; and 1 Samuel 8:15, 17). Of course, individual Israelites were also eagerly encouraged to contribute to those in need, with God's promise of 
supernatural recompense (see Deuteronomy 16:16; Proverbs 3:9; 19:17; 28:27;

Ecclesiastes 11:1; and 1 Chronicles 29:9). And as noted above, temple magistrates sustained the nation's indigent population through appropriations from state tax revenue.

New Testament writers applied the same essential ethic of social welfare to firstcentury Christians, who were then scattered throughout the Roman Empire. The Apostle Paul directed in 2 Thessalonians 3:10 that "if any man will not work, neither shall he eat" (see also 1 Thessalonians 4:11). And in extraordinary circumstances, one should first petition immediate family members for charity. Moreover, the Apostle Paul declared, "if any provide not for his own, and specially for those of his own house, he hath denied the faith and is worse than an infidel" (1 Timothy 5:8). Such insubordination could subject a believer to church discipline (viz., exclusion from the community, see Matthew 18:15-20; and 1 Corinthians 5:5).

Second, in situations where family could not (or would not) supply a destitute believer's basic needs of food, water and clothing (see Matthew 6:31-33; James 2:16; and 1 Timothy 6:8), members of the local (and if necessary, global) church community were commanded to help (see Acts 11:29; 24:17; Romans 15:26; 2 Corinthians 8:4; 9:1, 12 and Galatians 2:10). In that regard, Jerry Falwell Jr. lamented that "the [political] left wants to take money from their neighbors and give to the poor [through the government], instead of giving it themselves. That's what Christianity's all about."201

Scripture also admonished believers to honor and submit to (in almost all circumstances) God-ordained familial and ecclesiastical authorities, with the promise of

${ }^{201}$ CNN, "Jerry Falwell Jr.: Evangelicals Forgive Trump." 
His supernatural blessing. For example, the Apostle Paul exhorted: "Children obey your parents in the Lord .... Honor your father and mother, which is the first commandment with promise: that it may be well with you and you may live long on the earth" (Ephesians 6:1-3; see also Exodus 20:12; Deuteronomy 5:16; and Colossians 3:20). The Apostle Peter enjoined: "Wives, ... be submissive to your own husbands, ... like the holy women [in former times] who trusted in God" (1 Peter 3:1, 5a; see also 1 Corinthians 14:34; Ephesians 5:23-24; Colossians 3:18; and Titus 2:5). And the writer of Hebrews instructed: "Obey those [church elders] who have the rule over you" (Hebrews 13:7a; see also Matthew 23:2-3a; and 1 Thessalonians 5:12). In summary, in the Old and New Testaments, divine fiscal policy dictated that almost all charity be administered locally, through the support network of one's family and faith-community, who alone could provide adequate accountability regarding the distribution of social welfare assistance.

Correspondingly, in a radio show (airing in March of 2019), James Dobson likewise advocated that Americans should depend exclusively on their families and faithcommunities in extraordinary times of need. He affirmed that the seductively immoral bargain of "big government" was to string up a social safety-net (subsidized at tax-payer expense), which enabled citizens to sidestep the consequences of their sinful choices, while extinguishing incentive for self-reliance. Dobson claimed: "If you tell [teenage] girls that they can get ... liberated from their parents [and] ... have their meal-ticket handed to them ... by getting pregnant out of wedlock, ... it's going to happen." Here was a case in point: in 1965, 22 percent of African American children were born out of 
wedlock in the United States. Then Lyndon Johnson's "Great Society" was launched. And soon thereafter, that number soared to over 70 percent. From Dobson's perspective, the Democratic Party had thus proclaimed itself to be the savior of the poor. But in reality, its policies enslaved countless black communities in a perpetual cycle of impoverishment. And the only hope of ever breaking free, was to start trusting God instead of government. ${ }^{202}$

Jesus issued His followers an apposite, catch-all promise in Matthew 6:31-33: "Do not worry, saying, 'what shall we eat?' or 'what shall we drink?' or 'what shall we wear? ...' For your heavenly Father knows that you need all these things. But seek first the kingdom of God and His righteousness, and all these things shall be added to you." The Apostle Paul also assured faithful believers: "My God shall supply all your need according to his riches in glory by Christ Jesus" (Philippians 4:19; see also 2 Corinthians 9:8 and 1 Timothy 6:8). And time after time, Scripture recorded the Lord allowing His prodigal sons and daughters to fall into extreme poverty, to lovingly lead them back home to Himself, their families and to their faith-communities (see Deuteronomy 28:38; 1 Kings 17:7; Psalm 145:15; Joel 1; 2:25; Isaiah 5:6; 33:4; Jeremiah 12:11; 48:33; Hosea 4:3; and Luke 15:11-32).

The extensive review of evangelical works conducted for this study, did not unearth any additional relevant and important discussion among the most prominent evangelical supporters of Trump, regarding the enforcement of stringent requirements for receiving state welfare. Their relative silence on this issue may have been due to the fact

202 James Dobson, “Breaking the Bonds of Welfare - Part 1 with Dr. James Dobson's Family Talk,” March 27, 2019, video, 25:59. https://www.youtube.com/watch?v=u9GRFLgl8Ec (accessed March 5, 2020). 
that this has never been a consistent point of substantial emphasis for most evangelical church leaders, whose apprehensions of Biblical teaching on this subject differ appreciably (which will be discussed further in chapter four of this thesis). As a result, many sincerely pious, hard-working, and economically challenged evangelicals were beneficiaries of government entitlement programs.

\section{Summation}

As the 2016 presidential election approached, lay evangelicals had an excruciatingly challenging choice to make. It was difficult to deny that Donald Trump's character and comportment failed to reach that "reasonable threshold of behavior beneath which" their luminaries had insisted "public leaders should not fall," in order to ensure the "survival of our political system." ${ }^{203}$ As mouthpieces for the "Moral Majority," these ecclesiastical notables had preached for decades that, "character DOES matter" and that “you can't run a family, let alone a country, without it." And since there were so many “indications that [Donald Trump] was untruthful and immoral," could a bona fide follower of Christ really "ignore so many red flags," in an apparent pursuit of "raw political power?"204

Therefore, the crucial questions that each devout evangelical had to grapple with before casting his or her vote were these: 1) Does God want me to re-evaluate the historic, more puritanical prerequisites of evangelical leaders for America's commander-

\footnotetext{
203 The Presbyterian Lay Committee. "Declaration Concerning Religion.”

204 James Dobson. "Support Letter.”
} 
in-chief, in light of the extreme threat that the radical left has become to religious liberty? Is the Lord working, once again, in mysterious ways, to prosper America, advance His kingdom, and protect His followers, through a modern-day "King Cyrus," as many of our movement's contemporary prophets have declared? Should I pragmatically "plug my nose" and hop on the "Trump Train?" 2) Should I stick doggedly to evangelicalism's established guidelines of political engagement and support an unelectable third-party candidate who conforms to them, thereby virtually assuring a Clinton presidency? 3) Should I simply abstain from voting, trusting God to supernaturally accomplish His will, as I retreat from politics and society once again, into an isolated evangelical subculture of communities, and await Christ's return? 4) Should I support Clinton (whose statesmanship arguably befits a president, though her character is substantially suspect), knowing that if she wins the election, evangelical leaders will have no significant access to her administration, as she aggressively wages war (on behalf of her progressive base) against all the policy initiatives that my faith prescribes me to prioritize? WWJD? Ultimately, 81 percent of evangelicals chose Trump. However, a small, vocal, and articulate minority, reached a decidedly different conclusion. And the following chapter will examine their defense of their defection. 


\section{CHAPTER FOUR}

\section{EVANGELICAL OPPOSITION TO TRUMP}

\section{Introduction}

In the 2016 presidential election, nineteen percent of evangelicals did not vote for Donald Trump. In fact, many ardently opposed him, while dispensing sharp criticism toward their spiritual brothers and sisters who catapulted the nation's new controversial commander in chief to power. These outlying antagonists tended to be more affluent and educated, promulgating their arguments predominantly in academic, journalistic, and professional leadership circles, rather than on prime-time television. Perhaps their polemic was too reasoned and measured for network producers, in search of controversy to raise ratings; too out of touch with the Christian nationalism that was embraced by the religious right; and too out of step with the narrative that the progressive left preferred to propagate about the evangelical community. And as a group, these detractors lacked any significant organizational cohesion, in contradistinction to mainstream evangelicals, whose political institutions had been in business for the better part of four decades. The purpose of chapter four of this thesis is to let those minority voices be heard, so the reader can evaluate both sides of the evangelical argument regarding Trump's 2016 election bid, with sufficient nuance.

Trump's evangelical critics blushed in disgust at the following laundry list of accusations that were consistently levied at the Republican standard-bearer: quid pro quo with the Ukrainian president (for which he was impeached in 2019); allegations of sexual 
impropriety made by at least 17 women; ${ }^{205}$ illegal use of campaign funds as hush-money to conceal an affair with a porn star; separating and caging migrant families at the southern border; mocking disabled people; appearing in pornographic films and publications; consistent deceit and use of coarse and sexually offensive language; and claiming that he never asks God for forgiveness. ${ }^{206}$ In addition, numerous of Trump's closes associates have already faced criminal prosecution, including Roger Stone, Michael Cohen, Michael Flynn and Paul Manafort (among others).

These evangelical adversaries also tended to share the popular notion that the majority of Trump's supporters were fundamentally actuated by racism, sexism, Islamophobia, xenophobia, revenge and a lust for power. ${ }^{207}$ However, their critique concentrated on three preeminent areas of appurtenant evangelical concern: the conflation of the Gospel with politics; Trump's deficient moral leadership; and Trump's threat to social justice.

\section{The Conflation of the Gospel with Politics}

The first key reason why evangelical critics of Trump did not support him in the 2016 presidential election, was to prevent the conflation of the gospel with politics. Ever since the launching of Jerry Falwell's "Moral Majority" in 1979, evangelicals had been

\footnotetext{
${ }^{205}$ Meghan Keneally, "List of Trump's Accusers and Their Allegations of Sexual Misconduct," ABC News. June 25, 2019. https://abcnews.go.com/Politics/list-trumps-accusers-allegations-sexualmisconduct/story?id=51956410 (accessed February 25, 2020).

${ }^{206}$ Scott Eugene, "Trump Believes in God, But Hasn't Sought Forgiveness," CNN Politics. July 18, 2015. https://www.cnn.com/2015/07/18/politics/trumphas-never-sought-forgiveness/index.html (accessed February 27, 2020).

${ }^{207}$ Andrew Whitehead, et al. "Make America Christian Again," 147.
} 
uneasy about the public's perceived annexation of their movement by the Republican Party. In 1981, Billy Graham told Parade Magazine: "It would disturb me if there was a wedding between religious fundamentalists and the political right. The hard right has no interest in religion except to manipulate it." ${ }^{208}$ Evangelical pundit, Cal Thomas, likewise cautioned against this kind of confederacy because "political activism overwhelms the primary message, which is the gospel of Jesus Christ, the only thing that is able to truly change a life, and by extension, change a nation." ${ }^{209}$ In addition, this amalgamation of the sacred and secular, suggested that the church's chief underlying aim was, in reality, the raw pursuit of civic power and financial gain. For this very reason, Martin Luther refused to endorse "The Peasant's Revolt" in 1525 (dubbing them as "robbing, murdering hordes"), to safeguard his Protestant Reformation from association with avarice for state resources. ${ }^{210}$

First, to curb the conflation of the gospel with politics, evangelical critics of Trump repudiated the theology of Christian nationalism. They did not deny that "righteousness exalts a nation" (Proverbs 14:34) in principle. They simply argued that preaching the gospel was the only truly effective means of evangelism and that biblical revival could not, in any respect, be legislatively "coerced" via government fiat. ${ }^{211}$ Russel

\footnotetext{
${ }^{208}$ The Arizona Center for Judaic Studies, "Religion and the 2016 Election."

${ }^{209}$ Retro Report, “The Roots.”

${ }^{210}$ Martin Luther, "Against the Robbing, Murdering Hordes of Peasants," 1525. Quoted in, E. G. Rupp and Benjamin Drewery, Martin Luther, Documents of Modern History (London: Edward Arnold, 1970): 121126.

${ }^{211}$ Lifeway Groups Ministry. "What Does the Bible Say about Religious Liberty? Feat. Russell Moore" February 22, 2017, video, 1:37. https://www.youtube.com/watch?v=EjZ8z-trL2k
} 
Moore (president of the Southern Baptist Convention's “Ethics and Religious Liberty Commission") asserted, "you can't have social pressure that makes people conform to Christianity. Because if that does happen, you don't create Christians, you create fake Christians. ${ }^{.212}$ In addition, evangelical critics of Trump also acknowledged that God alone "raised up" politicians to positions of power (Psalm 75:7) and required submission to them as His ordained agents (Matthew 23:31; Romans 13:1; and 1 Peter 2:13-14). Notwithstanding, they painstakingly avoided mythologizing Trump through comparisons to biblical icons like Cyrus, Samson, Jehu, David, Solomon, or Nehemiah.

In his 2011 work entitled, Was America Founded as a Christian Nation?, John Fea (professor of history at Messiah College) concluded that the controversial question, posed by the book's title, could not "be answered with a simple yes or no." ${ }^{213}$ Fea posited that there was appreciable evidence of evangelical influence throughout early American history, especially at the state and local levels. Christian ministers commonly cited Scripture in their Sunday sermons to crusade for (or against) tendentious political causes like the American revolution and abolitionism. Almost all "state constitutions recognized God and Christianity, and many required officeholders to affirm Christian theology. Others maintained Christianity as the official and established state religion." 214

However, federal government officials have historically been markedly less deferent toward Christianity (and especially evangelicalism) when crafting legislation at

\footnotetext{
${ }^{212}$ The Gospel Coalition, "Russell Moore on Why Christians Should Fight for the Religious Liberties of False Religions," December 23, 2016, video, 2:33. https://www.youtube.com/watch?v=W3DuAJ24kIY

${ }^{213}$ John Fea, Was America Founded, 245.

${ }^{214}$ Ibid., 246.
} 
the national level. Fea devoted 5 chapters of this treatise to documenting the considerable latitude of conservative-liberal Christian and deist creeds, which America's founding fathers affirmed. He deduced that "if there was one universal idea that all the founders believed about the relationship between religion and the new nation, it was that religion was necessary in order to sustain an ordered and virtuous republic."215

However, Fea adamantly repudiated the Christian nationalist notion that America enjoyed an elite status as a "new Israel, ... in some kind of contractual relationship with God," 216 who had tasked them with reclaiming "control and power in the culture" (viz., Psalm 33:12 and 2 Chronicles 7:14). ${ }^{217}$ Russel Moore likewise spurned the notion that America was a "new Israel," with an exclusive, Biblically-assigned, "providential place in history." 218

Fea furthermore admonished evangelicals who, in the 2016 presidential election, were "looking for a strongman to protect them from the progressive forces wreaking havoc on their Christian nation." ${ }^{219}$ Instead believers had to learn "to get along in a

\footnotetext{
${ }^{215}$ Ibid., 246.

${ }^{216}$ John Fea, “Evangelical Fear Elected Trump,” The Atlantic. June 24, 2018. https://www.theatlantic.com/ideas/archive/2018/06/a-history-of-evangelical-fear/563558/ (accessed February 13, 2020).

${ }^{217}$ Justin Cober-Lake. "Why Are Evangelicals So Full of Fear? And So Supportive of Trump? Interview with Historian John Fea." PopMatters; Evanston (June 27, 2018). 1-13 (5).

${ }^{218}$ The Gospel Coalition. "Russell Moore on Whether America Is a Christian Nation". Filmed [July 2017]. YouTube video, 3:31. Posted [July 2017]. https://www.youtube.com/watch?v=MxVMltj_yd0

Moore also rejected the Dispensational view, which asserted that God's promises to national/ethnic Israel were unconditional (Gen. 15:12-21). Instead, Moore argued that they were unconditionally fulfilled in the person of Christ. Moore stated, "this does not necessitate that we support every political decision of the Israeli government .... Evangelical Protestants should recognize the promises to Israel as finding their Alpha and Omega in a virgin-conceived Man, not in a United Nations initiated state." (cited in Russel Moore, "From the House," 17-18).

${ }^{219}$ John Fea, "Evangelical Fear."
} 
society that [was] becoming increasingly pluralistic.."220 After all, evangelical leaders were often unable to even come to consensus concerning what Scripture taught on controversial issues. And without a papal-like figure or authoritative council, to which they could appeal to settle such matters, the united, utopic theocracy they envisioned was only practically possible, if Jesus Himself returned to earth to administrate it.

Accordingly, Rachel Held Evans (a well-known evangelical blogger) wrote, "the gospel isn't about protecting power and privilege, but rather about surrendering them until God's vision of justice is fulfilled." 221

Fea opined that prior to the 1980s, evangelicals had always "held some kind of cultural authority in US life, ... so they had no real need to turn to political power .... [But then] Christian voices began to get into power rather than counter it."222 Fea continued, "Martin Luther King ... was there to say [to American presidents], 'here's where there's injustice and what you need to do about it to be a man of moral integrity.' [However, many] court evangelicals are there to flatter Trump."223

Erick Ericson (an influential blogger and radio host) steadfastly avowed his "NeverTrump" position, accusing many of his fellow evangelical opinion-makers, who supported the president, of "syncretism," for "trying to blend patriotism with the church."

\footnotetext{
${ }^{220}$ Eerdmans Publishing. "Interview with John Fea, Author of BELIEVE ME". June 11, 2018, video, 30:20. https://www.youtube.com/watch?v=uagHfIvezqE

${ }^{221}$ Rachel Held Evans, "Donald Trump and a Tale of Two Gospels," RachelHeldEvans.com. January 28, 2016. https://rachelheldevans.com/blog/donald-trump-gospel-liberty (accessed February 27, 2020).

${ }^{222}$ Justin Cober-Lake, "Why Are Evangelicals So Full of Fear? And So Supportive of Trump? Interview with Historian John Fea," PopMatters (June 27, 2018): 7.

${ }^{223}$ Ibid., 8.
} 
Ericson bemoaned that they seemed to "argue that if the nation falls, the church falls .... But Christ has already risen[,] so the true church is in no danger of falling. The gates of hell shall not prevail. ${ }^{224}$

And Randall Balmer pronounced that "religion function[ed] best at the margins of society, not at the councils of power. Once you begin to hanker after political influence and power, you lose your prophetic voice." ${ }^{\prime 225}$ Indeed, if one of Trump's high-profile evangelical advisors ever publicly vocalized dissent toward the president's policies or tactics, his adversaries would quickly pounce on the quote to sow discord and evince division within the Republican ranks. Christ Himself had observed that "a house divided against itself will not stand" (Matthew 12:25b). And this maxim was particularly apropos to professional politics. Therefore, those with a seat at Trump's table had to speak with one voice. So, each evangelical leader was left with a clear choice: he or she could be God's “prophet” or Trump's “advisor." But they couldn't be both. ${ }^{226}$

Second, to curb the conflation of the gospel with politics, evangelical critics of Trump insisted that members of their movement should start advocating just as vigorously for the religious liberty of every American, as they had been doing for their own. After all, Christ taught His disciples to live by the "golden rule" (viz., "whatever you want men to do to you, do also to them," Matthew 7:12b).

\footnotetext{
${ }^{224}$ Erick Erickson, “Erick Erickson: Here's What I Decided After Pastors Begged Me to Reconsider My NeverTrump Stance", Washington Post, September 23, 2016. https://www.washingtonpost.com/news/actsof-faith/wp/2016/09/23/heres-what-i-decided-after-several-pastors-begged-me-to-reconsider-mynevertrump-stance (accessed February 27, 2020).

${ }^{225}$ Gordon Conwell University, "Randall Balmer."

${ }^{226}$ Ibid.
} 
Russel Moore pronounced, "religious freedom is not something that simply belongs to those who have the most votes at any given time. It [also] belongs to unpopular, religious minorities." ${ }^{227}$ And state power was a double-edged sword, which if one wished to wield, he would do well to remember that someday, it could end up in the hands of his worst enemy. Moore warned,

A government that can shut down mosques simply because they are mosques can shut down Bible studies because they are Bible studies. A government that can close the borders to all Muslims simply on the basis of their religious belief can do the same thing for evangelical Christians. A government that issues ID badges for Muslims simply because they are Muslims can, in the fullness of time, demand the same for Christians because we are Christians. ${ }^{228}$

Ben Howe (former evangelical staff member on Ted Cruz's 2016 presidential campaign) similarly cautioned believers who supported Trump, to brace themselves for the fierce and powerful backlash against their religious liberty, that was almost certain to come after his tenure in office concluded. Howe observed that their "culture war" had bewitchingly entrenched "a battlefield mentality" within their community, in which a "separate set of morals" (antithetical to Scripture) was often invoked when squaring off against political enemies. ${ }^{229}$

He sincerely sympathized with his spiritual brothers and sisters who compartmentalized faith and politics, begrudgingly casting their vote for the GOP

\footnotetext{
${ }^{227}$ Religion and Ethics Newsweekly, "Russell Moore on Donald Trump's Anti-Muslim Rhetoric," December 10, 2015, video, 1:16. https://www.youtube.com/watch?v=4Lppmnq4d5w

${ }^{228}$ Russell Moore, "Is Donald Trump Right About Closing the Border to Muslims?," Russellmoore.com. December 7, 2015. http:www.russellmoore.com/2015/12/07/is-donald-trump-right-about-closing-theborder-to-muslims (accessed March 25, 2020).

${ }^{229}$ Matt Lewis, "Matt Lewis Interviews Ben Howe,” August 11, 2019, video, 53:48. https://www.youtube.com/watch?v=ZfgatySGxmk
} 
nominee, as the lesser of two evils. ${ }^{230}$ However, Howe took strong issue with those who offered Trump their virtually unqualified endorsement, seeming to "celebrate" him as a quasi-biblical figure, who was somehow, inexplicably handpicked by God, based on "merit."231

Likewise, Andy Crouch (editor of "Christianity Today") recognized that most evangelicals who supported Trump, did so with "reluctant, strategic calculation," due to policy concerns. Nonetheless, those expressing "enthusiasm for a candidate like Trump [gave] our neighbors ample reason to believe that we doubt Jesus is Lord."232 And Russel Moore predicted, "it will take longer for [evangelicals] to recover" from their seeming unqualified support of Trump during his presidency, "than it did from the scandals of TV evangelists" in the 1980 s. $^{233}$

\section{Trump's Deficient Moral Leadership}

The second key reason why evangelical critics of Trump did not support him in the 2016 presidential election was his deficient moral leadership. As noted already in this thesis, evangelical leaders had historically insisted that America's commander in-chief had to set a high standard of integrity and civility, to inspire the nation. So, John Fea

\footnotetext{
${ }^{230}$ Ben Howe, The Immoral Majority, 64.

${ }^{231}$ Dennis Prager, “Dennis Prager Interviews Ben Howe,” August 20, 2019, video, 29:18. https://www.youtube.com/watch?v=WOEF8mv_yG8

${ }^{232}$ Andy Crouch, "Speak Truth to Trump," Christianity Today. October 10, 2016. http:/www.christianitytoday.com/ct/channel/utilities/print.html?type=article \&id=136354 (accessed March 24, 2020).

${ }^{233}$ CNN, "Evangelical Leader: Trump Support Hurts Christian Credibility,” October 10, 2016, video, 4:45. https://www.youtube.com/watch?v=O5VTG1NRj-s\&t=1s
} 
deeply lamented that "evangelicals would sell their moral authority to speak truth to the world[,] for a handful of Supreme Court Justices ... [that would help them] to win the culture war." History had shown that the long-term health of any "republic" was fundamentally dependent on a strong "moral fabric."”34

Albert Mohler (president of the Southern Baptist Convention), lambasted his

fellow evangelicals for backing a vulgarian like Trump, asking with bewilderment,

How could 'family values voters' support a man who had, among other things, stated openly that no man's wife was safe with him in the room? A casino titan who posed for the cover of Playboy magazine? ... This year, the Republican nominee is, in terms of character, the personification of what evangelicals have preached (and voted) against. Married three times, flaunting Christian sexual mores, building his fortune and his persona on the Playboy lifestyle, under any normal circumstances Trump would be the realization of evangelical nightmares, not the carrier of evangelical hopes." 235

In a 2016 CNN television interview, Mohler further pled with his evangelical audience,

Is it worth destroying our moral credibility to support someone who is beneath the baseline level of human decency for anyone who should deserve our vote? Long term, I think that's a far bigger question than the 2016 election . . . . I hope that every [evangelical] . . . thinks about what it's going to mean to ... publicly support someone that we would not allow our children to be around .... We [shouldn't] want this man as our next-door neighbor, much less as the inhabitant of 1600 Pennsylvania Avenue. ${ }^{236}$

Peter Wehner (evangelical journalist and former presidential speechwriter)

described Trump's temperament as "erratic, inconsistent," and with "a streak of crudity

\footnotetext{
${ }^{234}$ Eerdmans Publishing, "Interview with John Fea."

${ }^{235}$ R. Albert Mohler, Jr., "Donald Trump Has Created an Excruciating Moment for Evangelicals," Washington Post. October 9, 2016. https://www.washingtonpost.com/news/acts-of-faith/wp/2016 /10/09/donald-trump-has-created-an-excruciating-moment-for-evangelicals/?utm_term=.64cbebcc (accessed March 25, 2020).

${ }^{236}$ CNN, "Albert Mohler Discusses Trump and Evangelicals on CNN Tonight," October 12, 2016, video, 8:05. https://www.youtube.com/watch? $=$ exvuCgWiIGk
} 
and cruelty." He shows "contempt" for the "weak and vulnerable," as he "bullies and threatens people he believes are obstacles to his ambitions." ${ }^{237}$ Michael Gerson (evangelical journalist and former presidential advisor) added that Trump's personal deportment has "coarsened our culture, given permission for bullying, complicated the moral formation of children, undermined standards of public integrity, and encouraged cynicism about the political enterprise." 238

In a 2015 article entitled "Narcissist in Chief," Jim Wallis (the self-identified, leftwing evangelical founder of "Sojourners" magazine and ministry), characterized Trump as a "lover of money, luxury and power" who lacked "reason, respect, experience, maturity, truth, civility . . compassion [and] empathy." ${ }^{239}$ David Gushee (professor of ethics at Mercer University and former president of "Evangelicals for Human Rights") said, "Christian Right people used to be some of our culture's leading advocates for a restoration of sound character in America. Character counts, they said. We need to fight all those forces that corrode our culture and cheapen human life, they said. We need men of strong, Christ-like character to lead our families, churches, and nation, they said. Oh well." ${ }^{240}$ Consequently, as the 2016 presidential election approached, Michael Gerson declared,

\footnotetext{
${ }^{237}$ Peter Wehner, "Why I Will Never Vote for Donald Trump," Ethics and Policy Center. N.D. https:/eppc.org/publications/why-i-will-never-vote-for-donald-trump/ (accessed February 27, 2020). 
Evangelical Christians are not merely choosing a certain political outcome. They are determining their public character - the way they are viewed by others and, ultimately, the way they view themselves .... In legitimizing the Republican nominee, evangelicals are not merely accepting who he is; they are changing who they are .... By associating with this movement, evangelicals will bear, if not the mark of Cain, at least the mark of Trump. ${ }^{241}$

It's worth noting again that all of Trump's aforementioned evangelical critics had the luxury of voicing their dissent within academic, journalistic, and professional leadership contexts, where for the most part, they enjoyed appreciation from affluent colleagues, for retrieving cultural respectability for their movement's integrity. But that was not the case for Beth Moore (prominent evangelical speaker and author), who tweeted about the tragedy of sexual assault, immediately after Trump's infamous “Access Hollywood" tape was released (in October of 2016). Though she never even mentioned his name, the phones at Moore's ministry headquarters rang off the hook, as staff members listened to scores of complaints from her long-time supporters. And she paid a steep cost, both financially and professionally. Books sales dropped off drastically, as did attendance at the nation-wide rallies she led for lay (rank and file), evangelical women. One 56-year-old participant named Shelly, tellingly remarked, "I don't think this is the avenue for political discussions ... . I think it should stay focused on God."242 Paradoxically, though Moore's critique was comparatively brief and carefully guarded, she may have been Trump's most truly courageous evangelical critic of all.

\footnotetext{
${ }^{241}$ Michael Gerson, "Evangelicals Must Not Bear the Mark of Trump,” Washington Post. June 2, 2016. https:/www.washingtonpost.com/opinions/evangelicals-may-carry-the-mark-oftrump/2016/06/02/dc0f59b4-28eb-11e6-ae4a--3cdd5fe74204_story.html?utm_term=.f0f6f982fb65. (accessed February 25, 2020).

${ }^{242}$ Emma Green, "The Tiny Blond Bible Teacher Taking on the Evangelical Political Machine," The Atlantic. October 2018. https://www.theatlantic.com/magazine/archive/2018/10/beth-moore-biblestudy/568288 (accessed February 27, 2020).
} 


\section{Trump's Threat to Social Justice}

The third key reason why evangelical critics of Trump did not support him in the 2016 presidential election, was Trump's threat to social justice. Since the mid-twentieth century, this hot-button issue began gradually reemerging on the evangelical radar once again, due principally to the 1947 landmark work of Carl Henry (professor at Fuller Theological Seminary), entitled The Uneasy Conscience of Modern Fundamentalism. The magazine, "Christianity Today" (founded by Billy Graham in 1956) also routinely featured related articles to stoke awareness and activism. In 1973, 55 influential leaders signed "The Chicago Declaration of Evangelical Social Concern," which called for racial reconciliation, shrinking the monetary gap between classes, women's rights, and economic relief for the poor. And in 2005, the National Association of Evangelicals published a position paper advocating for financial justice, human rights, and environmental protection. At present, America is perhaps the only nation on earth, whose evangelical citizens don't primarily support political parties which favor the marginalized members of society. According to John Fea, that is because few (if any) other countries exist, in which evangelicals have ever exercised any significant sway over public policy. $^{243}$

While Donald Trump had cited Leviticus 24:20 as his "favorite" Bible verse (viz., “an eye for an eye"), ${ }^{244}$ Jim Wallis insisted that God's compassion was Scripture's

\footnotetext{
${ }^{243}$ Gordon Conwell University, "Randall Balmer."

${ }^{244}$ Nolan Maccaskill, “Trump's Favorite Bible Verse: 'Eye for an Eye,"” Politico. April 4, 2016. https:/www.politico.com/blogs/2016-gop-primary-live-updates-and-results/2016/04/trump-favorite-bibleverse-221954 (accessed February 27, 2020).
} 
prevailing theme. And Wallis claimed to have identified over two thousand sacred texts, which enjoined all governments and individuals to protect and provide for the most vulnerable and least advantaged citizens in their communities. ${ }^{245}$ Perhaps the most cogent, concomitant passage in the Old Testament is Micah 6:8, which states, "He has shown you, O man, what is good; and what does the LORD require of you but to do justly, to love mercy, and to walk humbly with your God?" In the New Testament, Jesus inaugurated His public ministry by unveiling His chief, targeted demographic, announcing in Luke 4:18, "the Spirit of the LORD is upon Me, because He has anointed Me to preach the gospel to the poor; He has sent Me to heal the brokenhearted, ... [and] to set at liberty those who are oppressed." And when Christ returns, He also indicated that people will be granted (or denied) access into His earthly (millennial) kingdom, based (at least in part) on whether they provided food, water, lodging, clothing and visitation in prison to the "least" esteemed and empowered among them (viz., referencing the Jewish people specifically, see Matthew 25:31-46).

Moreover, Christianity's founder declared that after loving God, the second greatest command of all was to love one's "neighbor" (Matthew 22:39, whom Wallis identified in context, as "the one whose different from you [and] outside your path." In contrast, he claimed that Trump's dehumanizing of impuissant groups like ethnic minorities and immigrants, was the work of an "antichrist." ${ }^{246}$ Rachel Held Evans likewise asserted, "the kind of people Donald Trump and the Religious Right deem

\footnotetext{
${ }^{245}$ Grace Cathedral, San Francisco. "The Forum with Jim Wallis: Christ in Crisis,” November 3, 2019, video, 104:12. https://www.youtube.com/watch?v=eMjCYRgkKDI ${ }^{246}$ Ibid.
} 
acceptable collateral damage in their quest for power - the poor, the oppressed, the marginalized, the hated minorities - are the very people Jesus prioritized."247

For example, evangelical critics emphatically denounced Trump for launching his presidential campaign by carelessly broad-brushing Mexican immigrants as "rapists and murderers." ${ }^{248}$ And John Fea promulgated that Trump appealed to the "worst side" of evangelicals, stirring up "nostalgia for a white world in which they held power." 249 His slogan of "Make America Great Again," served as a dog-whistle that emboldened bigots who sought to suppress people of color. ${ }^{250}$ Thus, Michael Gerson proclaimed, “every strong Trump supporter has decided that racism is not a moral disqualification in the president of the United States." 251

Russell Moore added, "when we treat people in demeaning ways, we are assaulting the image of God." ${ }^{252}$ And Moore reminded his readers that "a vast majority of Christians, on earth and in heaven, are not white and have never spoken English .... [And] the man on the throne in heaven is a dark-skinned, Aramaic-speaking 'foreigner'

\footnotetext{
${ }^{247}$ Rachel Held Evans, "Donald Trump.”

${ }^{248}$ Martin Medhurst, "The Religious Rhetoric," 9.

${ }^{249}$ Eerdmans Publishing, "Interview with John Fea."

${ }^{250}$ John Fea, Believe Me, 155.

${ }^{251}$ Michael Gerson, "The Temptation."

${ }^{252}$ Religion and Ethics Newsweekly, "Russell Moore on Donald Trump's Anti-Muslim."
} 
[Jesus Christ], who is probably not all that impressed by chants of 'Make America Great Again." ${ }^{253}$

In April of 2016, Wallis, joined by over 50 faith leaders, issued a statement opposing Trump's candidacy entitled "Called to Resist Bigotry," which read,

This is no longer politics as usual, but rather a moral and theological crisis .... Donald Trump ... is bringing our nation's worst instincts to the political surface . ... [His] highly visible and vulgar racial and religious demagoguery presents a danger but also an opportunity .... By confronting a message so contrary to our Christian values, ... [we can] put our true faith ... forward in the midst of national ... confusion. ${ }^{254}$

And in September of 2016, 80 additional evangelical luminaries affirmed the following declaration: "Because we believe that racial bigotry has been a cornerstone of [Trump's] campaign, it is a foundational matter of the gospel for us in this election .... [We] simply will not tolerate the racial, religious, and gender bigotry that Donald Trump has consistently and deliberately fueled." ${ }^{, 25}$ Finally, Wallis solemnly warned that ministers who eschewed social issues for fear of being criticized for getting sidetracked from the gospel, risked losing the next generation to the Christian faith. ${ }^{256}$

\footnotetext{
${ }^{253}$ Russell Moore, “A White Church No More,” New York Times. May 6, 2016. https://www.nytimes.com/2016/05/06/opinion/a-white-church-no-more.html?ref=opinion\&_r=1 (accessed February 27, 2020).

${ }^{254}$ Jim Wallis, "Christians Called to Resist Trump's Bigotry,” Huffington Post. April 29, 2016. https://www.huffpost.com/entry/christians-called-to-resi_b_9809222 (accessed February 27, 2020).

${ }^{255}$ N.A. "A Declaration by American Evangelicals Concerning Donald Trump." Change.org. September 29, 2016. https://www.change.org/p/donald-trump-a-declaration-by-american-evangelicals-concerningdonald-trump (accessed February 27, 2020).

${ }^{256}$ Grace Cathedral, San Francisco. "The Forum.”
} 


\section{Summation}

As election-day 2016 arrived, for evangelical critics of Trump, the choice seemed crystal clear. Even if it meant Hillary Clinton assumed the presidency, despite her blatant character flaws; an almost-certain denial of evangelical access to her administration; and her progressive policy-agenda that would wage war against causes most of them deeply believed in (like religious liberty and opposition to abortion), they still could not, in good conscience, cast their votes for Donald J. Trump. No matter the cost, they would trust God with the outcome. There was no doubt in their minds - that's what Jesus would do.

And even after Trump's 77-point electoral college victory, their protests persisted. In January of 2017, the National Association of Evangelicals published an open letter to Trump which stated: "The Bible teaches us that each person - including each refugee, regardless of their country of origin, religious background, or any other qualifier - is made in the Image of God, with inherent dignity and potential. Their lives matter to God, and they matter to us." ${ }^{257}$ And Brian MacLaren (a renowned author, who is considered on the far-left of evangelicalism), insisted unequivocally that there was no "highway of cooperation with Trump," comparing pastors who would not publicly denounce him, to citizens of Nazi Germany, who stayed silent anent Hitler's atrocities. MacLaren adjured all who attended their churches to leave. ${ }^{258}$

\footnotetext{
${ }^{257}$ Leith Anderson, "Letter to President Trump on Executive Order on Refugees," January 29, 2017. https://www.nae.net/letter-president-trump-executive-order-refugees (accessed February 27, 2020).

${ }^{258}$ Green Mountain Academy, "Brian McLaren: Being Church in the Trump Era (Part 2)," February 21, 2017, video, 51:41. https://www.youtube.com/watch?v=OnKXnFqCHsk
} 
Ultimately, many bewailed that the term "evangelical" had been politically hijacked, ${ }^{259}$ having become (after the election) synonymous with the word "hypocrite."260 And some jettisoned the label entirely. ${ }^{261}$ While still others, like Rod Dreher (in his April 2017 article entitled, "The Benedictine Option"), summoned the faithful to retreat from society once again, to reconstruct their subcultural network of monastic-like communities. Thus, "embracing their minority status [evangelicals could] "revive their faith." ${ }^{262}$ Indeed, in so many ways, history was seeming to repeat itself.

${ }^{259}$ Mark Labberton, ed., Still Evangelical: Insiders Reconsider Political, Social, and Theological Meaning (Downers Grove, IL: Intervarsity Press, 2018): 16-17.

${ }^{260}$ Timothy Keller, "Can Evangelicalism Survive Donald Trump and Roy Moore," The New Yorker. December 19, 2017. https://www.newyorker.com/news/news-desk/can-evangelicalism-survive-donaldtrump-and-roy-moore (accessed February 27, 2020).

${ }^{261}$ Martin Medhurst, "The Religious Rhetoric," 3.

${ }^{262}$ Rod Dreher, "The Benedict Option: By Embracing Their Minority Status, Christians Can Revive Their Faith," Spectator 333:9842 (April 15, 2017): 12-13. 


\section{CHAPTER FIVE}

\section{CONCLUSION}

This concluding chapter will first discuss three implications of this study regarding religion's impact on American politics. Second, bearing in mind the historical overview of evangelical participation in American politics (discussed in chapter two), it will compare and contrast the key arguments of prominent evangelicals who supported Trump in the 2016 presidential election (discussed in chapter three), with those of prominent evangelicals who opposed Trump (discussed in chapter four). Thus, the reader will be furnished with a synopsis of the findings of this thesis, which provided a more fully nuanced understanding of evangelical support for, and opposition to, Donald Trump in the 2016 presidential election.

\section{Implications Regarding Religion's Impact on American Politics}

This study suggested four primary implications regarding religion's impact on American politics. First, the evangelical religious community has long exercised substantial influence within American politics, due primarily to the fact that its adherents constituted over one-quarter of the total U.S. population. Although they exerted no appreciable sway within the Democratic Party, they were the Republican Party's largest and most historically reliable base of supporters and were ignored by conservative politicians at their own electoral peril. And the majority of evangelicals desired to marshal government power to legislate their conception of morality to perpetuate 
Christian nationalism (a desire that GOP candidates consistently stoked during their campaigns, to energize these believers to turn out to support them on election day).

Second, throughout America's history, the impact of evangelicalism on American politics had ebbed and flowed, based principally upon whether its leaders perceived the government to be interfering with their ability to guide their own ministries according to biblical principles, as they interpreted them. However, they tended to mobilize their followers by waging a culture war over key issues: most notably, the inclusion of official prayer and Bible reading in public school operations, opposition to abortion, as well as their religious freedom to discriminate based on race (prior to the 1980s) and based on sexual orientation (after same-sex marriage was legalized nation-wide by SCOTUS in 2015).

Third, evangelicals have continued to exert significant political influence to this day, and were a key impetus in electing Donald Trump in 2016. Not only have they forced the GOP to adjust its party platform in light of the issues that evangelicals have prioritized, but they have curtailed the extent to which politicians on the left have been able to enact progressive policies, while serving in office.

Fourth, the findings from this study were not just important for understanding more about religion and politics in America. They also helped provide insight into how religion affected voting behavior. Political scientists have identified personal characteristics, party affiliation, issue positions and economic factors as significant determinants, used by voters, to evaluate candidates. But this study also uncovered that since most evangelicals believed that God would either bless or curse America based on 
whether its citizens elected politicians who governed according to biblical principles (as evangelicals interpreted Scripture), other concerns typically became peripheral matters in the minds of this substantial bloc of voters.

\section{Summary of Arguments of Evangelicals Who Supported Trump}

Evangelical leaders who supported Trump's presidential campaign offered their arguments for doing so, primarily via television and social media outlets, to persuade lay (rank and file) evangelicals to join them in voting for the GOP nominee. Their apologetic focused on three key areas: evangelical theology; evangelical access; and evangelical policies.

\section{Evangelical Theology}

Evangelicals who supported Trump consistently highlighted a handful of salient Scriptural texts, which were foundational to their theology of politics, and steered them toward adopting the ideology of Christian nationalism. For example, Proverbs 14:34 stated, "righteousness exalts a nation, but sin is a reproach to any people." This immutable principle also insinuated a divine promise to bless or curse all countries throughout human history, contingent on their compliance with God's applicable commands, which were recorded in the Bible. Because America was founded as a Christian nation, its citizens had historically enjoyed virtually unprecedented prosperity and protection. Consequently, God had elevated the United States (like a "city on a hill"), as a global hegemon, through which to showcase His bounty and galvanize the world to 
embrace Christianity. And completing this divine commission necessitated that evangelicals keep control of government power, to legislate moral "righteousness" within American society.

These evangelicals also highlighted Psalm 33:12 which proclaimed, "blessed is the nation whose God is the Lord, the people He has chosen as His own inheritance." They believed the United States had entered a covenant with God as a "chosen" people, tantamount to His agreement with Israel in the Old Testament. Though at present, America had violated this divine contract, God's offer of restoration through repentance was still available, as articulated in 2 Chronicles 7:14, "if my people, who are called by my name, will humble themselves, and pray and seek my face, and turn from their wicked ways, then will I hear from heaven, and will forgive their sin and heal their land."

These evangelicals acknowledged that God alone promoted political rulers to power (Psalm 75:6-7; Romans 13:1) and that believers should appropriately honor and obey them (Matthew 22:31; 1 Peter 2:13-14). And in 2016, the Lord had raised up Trump, as He had other flawed characters in Scripture (viz., Cyrus, Samson, Jehu, David, Solomon, and Nehemiah), to seek the welfare of all Americans (and especially His faithful followers), regardless of Trump's personal motivation for doing so.

\section{Evangelical Access}

Evangelicals who supported Trump acknowledged that both he, and his democratic challenger (Hillary Clinton), had conspicuous character deficiencies. However, unlike his left-leaning rival, Trump had routinely reached out to their faith 
community with utmost openness and congeniality, providing their leaders with consistent access to his campaign. He also invited them to lay hands on him in prayer at public events, solicited their counsel, and pledged, upon being elected, to place them in strategic positions of power within his cabinet and administration.

These evangelicals also conceded that in light of his habitually disreputable comportment, Trump was an inauspicious archetype for their ideals. However, left-wing progressives posed an imminent and exigent threat to America's "moral majority." And they were not electing a national pastor, but a political powerbroker, with the indomitable courage and tenacity necessary to fight for their children's future - and win. Liberals weren't going to like him (or them) anyway, no matter how compassionately they packaged their conservativism. So, they surrendered to let Trump be Trump, emphasizing that the cynosure of Christianity was forgiveness, and that only Americans who were "without sin" themselves, were qualified to "cast the first stone" at the GOP nominee (see John 8:7).

\section{Evangelical Policies}

Evangelicals who supported Trump emphasized that Christians should vote for a president, based primarily on his or her stance on key issues, rather than the candidate's temperament. And Trump promised to champion six critical policies, which evangelicals had prioritized.

First, Trump promised to nominate conservative judges, publishing an appealing list of potential appointees, nine months before the election. Though the founding fathers 
had designated the judiciary as the government's weakest branch, progressives had adroitly undertaken to "legislate from the bench," side-stepping the Congressional system of checks and balances, that was enshrined within the Constitution. Therefore, the courts had become the nation's premiere ideological battlefield. So, safeguarding a conservative majority on SCOTUS, had become the sine qua non of political priorities.

Second, Trump promised to protect religious liberty, which evangelicals insisted was under unprecedented attack, most blatantly through neoteric legislation that sought to safeguard the rights of women (especially to maintain access to contraception and abortion), as well as those of the LGBT community. Notwithstanding, these believers simply wanted to authentically live out their faith in the public square and proclaim the gospel freely. And Trump's deference toward them in this regard, gave progressives pause, who might otherwise aggressively pursue an anti-evangelical agenda.

Third, Trump promised to promote Israel's welfare, which these evangelicals believed was a principal linchpin to sustaining God's blessing on America. After all, the Lord had made an unconditional covenant to bless or curse nations and individuals, based on how they conducted themselves toward Israel, until the end of time (Genesis 15:1221).

Fourth, Trump promised to advance the pro-life agenda. And these evangelicals maintained, based on numerous biblical texts, that life began at conception. Therefore, abortion was iniquitous in the eyes of God, except in extraordinary circumstances, in which there was a substantial threat to the life and health of the mother (see Exodus 21:22-25; Judges 13:5; Job 31:15; Psalm 51:5; 71:6; and Luke 1:15, 44). 
Fifth, Trump promised to effectively enforce immigration law, establishing this issue as a centerpiece of his campaign. These evangelicals enthusiastically joined him in calling for an end to chain-migration, which would be replaced with a more merit-based system. And they likewise applauded Trump's pledge to curtail Muslim immigration specifically, which they believed not only threatened domestic security, but more importantly, American Christian nationalism.

Sixth, Trump promised to perpetuate Republican, fiscal conservativism, ensuring that the inveterate economic and political power structures remained securely in place. Many of these evangelicals believed that the biblical ideal envisioned minimal state taxation (to keep government small), along with stringent welfare requirements; namely, that almost all charity would be dispensed locally, through one's family, church, and community, to guarantee requisite accountability.

\section{Summary of Arguments of Evangelicals Who Opposed Trump}

Evangelical leaders who opposed Trump's campaign offered their arguments for doing so, primarily via academic, journalistic, and professional leadership venues, both to persuade fellow believers not to support the GOP nominee, and to preserve their movement's reputation for probity. Their critique focused on three key areas: the conflation of the Gospel with politics; Trump's deficient moral leadership; and Trump's threat to social justice. 
The Conflation of the Gospel with Politics

Evangelicals who opposed Trump strongly objected to the conflation of the gospel (which sought to provide eternal salvation) with politics (which sought to procure state resources). They also disavowed Christian nationalism and its subsidiary suppositions that moral "righteousness" could (and should) be legislated via government fiat, to secure God's blessing on America; that this country was founded as a Christian nation; and that it enjoyed a special covenant with God, akin to His compact with Old Testament Israel.

These evangelicals also acknowledged that God alone promoted political rulers to power (Psalm 75:6-7; Romans 13:1) and that believers should appropriately honor and obey them (Matthew 22:31; 1 Peter 2:13-14). However, they painstakingly eschewed comparisons of Trump to iconic biblical figures, and staunchly refuted the sentiment that God had raised him up, based on any personal merit whatsoever.

These evangelicals advocated just as vigorously for the religious liberty of all Americans, as they did for their own, not merely to follow the "golden rule" (Matthew 7:12), but because they recognized that someday state power could fall into the hands of those who were most hostile toward their own beliefs. And they observed that members of their movement who sought a seat at the table in Trump's administration, were perpetually constrained from voicing dissent from the president, for the sake of party unity. Therefore, they could either be God's prophet or Trump's advisor. But they couldn't be both. 
These evangelicals insisted that their spiritual brothers and sisters should not lend their movement's public credibility to Trump's campaign, even if that resulted in a Clinton presidency. And while some dogmatically held that no evangelical should vote for him, others affirmed that if one did so because Trump was perceived to be the "lesser of two evils" (due to policy concerns), his presidency should not be celebrated, and his flaws should be candidly acknowledged.

\section{Trump's Deficient Moral Leadership}

Evangelicals who opposed Trump conceded that in respect to character, neither he, nor Hillary Clinton exemplified their values and ideals. However, Trump was unwontedly repugnant, because his blatant duplicity and paucity of civility, conveyed an utter contempt for the dignity of the office to which he aspired.

And these evangelicals deeply lamented the fact that so many of their fellow believers would forfeit the chance to commend the highest standard of morality within secular society, by lending their credibility to Trump's campaign, in order to win the culture war. By doing so, they not only significantly altered public perception of their movement for the worse, but who they were at their core as well.

\section{Trump's Threat to Social Justice}

Evangelicals who opposed Trump argued that his actions, rhetoric, and policies posed an acute and persistent threat to social justice. They purported that the primary responsibility of government officials was to protect and provide for the most vulnerable 
and least advantaged members of society (Micah 6:8; Matthew 22:39; 25:31-46; Luke 4:18). Notwithstanding, Trump's consistent demeaning and dehumanizing of the downtrodden, served as a dog-whistle that reinvigorated and emboldened racism, bigotry, and oppression.

The response of these evangelicals to the six policy issues, which their fellow believers (who supported Trump) had prioritized, was mixed. First, they did not express a preference for the nomination of conservative judges. Second, they emphasized the exigency of defending the religious liberty of all Americans, not just evangelicals. Third, they endorsed America's promotion of Israel's welfare, but not in any superlative sense, because they rejected the dispensational interpretation of Genesis 15:12-21 (viz., that God's covenant to "bless" or "curse" individuals and people-groups, based on how they treated the Jewish state was unconditional, and was still being divinely enforced). Fourth, they generally embraced Trump's pro-life agenda. Fifth, they argued that U.S. immigration law should be modified to exhibit enhanced levels of Christ-like charity and compassion, particularly in respect to refugees. And sixth, rather than seeking to perpetuate, Republican, fiscal conservatism, they advocated for more generous, and less restrictive government policies regarding social welfare distribution.

\section{Final Summation}

The key question addressed in this thesis was as follows: why did so many evangelicals support Donald Trump in the 2016 presidential election, despite the fact that his character and comportment seemed so out of sync with their professed values? The 
answer is that these evangelicals emphasized the preeminent importance of his willingness to grant their leaders access to his administration and support their policy agenda. This would enable them to live out their faith authentically, proclaim the gospel freely and revive Christian nationalism (based on their theological interpretation of Scripture), to secure God's protection and prosperity for the nation. Conversely, evangelicals who opposed Trump emphasized the preeminent importance of believers committing to lend their credibility, only to presidential candidates who upheld a high standard of moral decency and civility, so the gospel was disassociated from the pursuit of state power and resources, and social justice for the most vulnerable members of society was maintained.

Generally speaking, evangelical leaders who supported Trump, chiefly tailored their arguments to lay (rank and file) believers, who were relatively unconcerned with how their movement would be perceived in academic, journalistic, and professional leadership circles, if Trump won the election. While evangelical leaders who opposed Trump, chiefly tailored their arguments to more affluent believers, who would typically be less significantly impacted by progressive policy shifts that occurred at the grassroots level, if Clinton won the election. Human beings are seldom acutely aware of how their own biases affect the process by which they evaluate information and make decisions. Undoubtedly, the status of, and circumstances within which individual evangelicals were situated, played a significant role in how many of them answered the question of WWJD (“what would Jesus do?"), in respect to the 2016 presidential election. And that doesn't necessarily indicate that these evangelicals were hypocrites, just that they were human. 
With the 2020 presidential campaign now in full swing, evangelicals must reevaluate whether they should support or oppose Trump's reelection. And it is likely that the members of their movement will continue to be divided over the same fundamental issues. But it still remains to be seen whether history will indeed repeat itself once again. 


\section{REFERENCES}

ABC News. "Jerry Falwell Jr. on President Trump: He 'Doesn't Say What's Politically Correct."' Filmed [August 2017]. YouTube video, 10:54. Posted [August 2017]. https://www.youtube.com/watch?v=_QqAZydbTE

Abed, Marwa. "Get Out the Muslim Vote." Islamic Horizons 41 (May/June 2012): 3.

Abramson, Alan. "What Trump Has Said About a Muslim Registry." ABC News. November 18, 2016. Accessed March 21, 2020. https://abcnews.go.com/Politics/trump-muslim-registry/story?id=43639946

American Academy in Berlin. "Frances FitzGerald: Evangelicals and Trump's Republican Party.” Filmed [October 2018]. YouTube video, 1:22:16. Posted [November 2018]. https://www.youtube.com/watch?v=xJ2tGPeq6Do

Anderson, Leith. "Letter to President Trump on Executive Order on Refugees." National Association of Evangelicals. January 29, 2017. Accessed February 27, 2020. https://www.nae.net/letter-president-trump-executive-order-refugees/

Argyle, Lisa P., Marcus Arrajj, Skylar Covich, E.G. Garay, Julian Gottlieb, Heather E. Hodges and Eric R.A.N. Smith. "Economic Performance and Presidential Trait Evaluations: A Longitudinal Analysis.” Electoral Studies, 43 (2016): 52-62.

Ayers, John W. "Changing Sides: 9/11 and the American Muslim Voter." San Diego State University Review of Religious Research 49:2 (December, 2007): 187-198.

Baklinski, Pete. “Trump Signs Order Protecting Freedom for Opponents of Abortion, Gay 'Marriage'”. Lifesite. May 4, 2017. Accessed February 24, 2020. https://www.lifesitenews.com/news/breaking-trump-signs-order-protectingfreedom-for-opponents-of-abortion-gay

Balmer, Randal. Evangelicalism in America. Waco, TX: Baylor University Press, 2016.

God in the White House: How Faith Shaped the Presidency from John F. Kennedy to George W. Bush. San Francisco: HarperOne, 2008.

. Mine Eyes Have Seen the Glory: A Journey into the Evangelical Subculture in America. $4^{\text {th }}$ ed. New York: Oxford University Press, 2006.

. The Making of Evangelicalism: From Revivalism to Politics and Beyond. Waco, TX: Baylor University Press, 2010. 
. "The Real Origins of the Religious Right.” Politico. May 27, 2014. Accessed February 28, 2020. https://www.politico.com/magazine/story/2014/05/religiousright-real-origins-107133\#.U4eDQ_ldW2E

. Thy Kingdom Come: How the Religious Right Distorts the Faith and

Threatens America: An Evangelical's Lament. New York: Basic Books, 2007.

Banwart, Doug (2013). "Jerry Falwell, the Rise of the Moral Majority, and the 1980 Election." Western Illinois Historical Review 5 (2013): 133-57.

Bardi, Jennifer. "King of This World: Irreligious Trump Remains Popular with Evangelicals. The Humanist (November-December, 2019): 8.

Barkun, Michael. Religion and the Racist Right: The Origins of the Christian Identity Movement. Chapel Hill: University of North Carolina Press, 1997.

Barrett-Fox, Rebecca. “King Cyrus President: How Donald Trump's Presidency Reasserts Conservative Christians' Right to Hegemony." Humanity and Society 42:4 (2018). 502-522.

Bartkowski, John P., Aida I. Ramos-Wada, Chris G. Ellison, and Gabriel A. Acevedo. "Faith, Race-Ethnicity, and Public Policy Preferences: Religious Schemas and Abortion Attitudes Among U.S. Latinos." Journal for the Scientific Study of Religion, 51:2 (June 2012): 343-358.

Barton, David. America's Godly Heritage, $2^{\text {nd }}$ ed. Aledo, TX: WallBuilder Press, 1993.

Beaty, Katelyn. "Why Evangelical Women Leaders Don't Talk About Politics.” Religion and Politics. December 19, 2017. Accessed February 13, 2020.

https://religionandpolitics.org/2017/12/19/why-evangelical-women-leaders-donttalk-about-politics/

Bebbington, David. Evangelicalism in Modern Britain: A History from the 1730s to the 1980s. London: Unwin Hyman, 1989.

Berlinerblau, Jacques. "Donald J. Trump, the White Evangelicals, and Martin Luther: A Hypothesis." Interpretation: A Journal of Bible and Theology 73:1 (2019): 18-30.

Besser, James D. “High Noon for Jewish Politics.” Baltimore Jewish Times 220: 6, (December 9, 1994): 48.

Big Think. "Is the Trump Presidency a Religious Cult?" Filmed [April 2018].

YouTube video, 8:33. Posted [April 2018].

https://www.youtube.com/watch?v=KS7pnPlQLcY. 
Blake, William. "God Save This Honorable Court: Religion as a Source of Judicial Policy Preferences." Political Research Quarterly, 65:4 (December 2012): 814826.

Blumenthal, Max. "Agent of Intolerance." The Nation. May 28, 2007. Accessed February 28, 2020. https://www.thenation.com/article/archive/agent-intolerance

Boyd, Gregory A. The Myth of a Christian Nation: How the Quest for Political Power is Destroying the Church. Grand Rapids, MI: Zondervan, 2005.

Braunstein, Ruth. Prophets and Patriots: Faith Across the Political Divide. Oakland, CA: University of California Press, 2017.

Brody, David, and Scott Lamb. The Faith of Donald Trump: A Spiritual Biography. New York: Harper Collins, 2018.

Brookings Institution. "The Role of Religion in American Politics." Filmed [October 2010]. YouTube video, 7:16. Posted (October 29, 2010]. https://www.youtube.com/watch?v=pRGLlY44qHg

Burleigh, Nina. "Does God Believe in Trump? White Evangelicals are Sticking with Their 'Prince of Lies'; Evangelicals Worship Their President but Seem Blind to the Multitude of Signs that Donald Trump's Holy Trinity is 'Me, Myself and I."' Newsweek. October 13, 2017. Accessed February 18, 2020. https://www.newsweek.com/2017/10/13/donald-trump-white-evangelicalssupport-god-677587.html

. "Evangelical Christians Helped Elect Donald Trump, but Their Time as a Major Political Force Is Coming to an End; Republicans Relied on Evangelicals for Decades, but a Political Reckoning is Afoot." Newsweek. December 21, 2018. Accessed March 24, 2020. https://www.newsweek.com/2018/12/21/evangelicalsrepublicans-trump-millenials-1255745.html

Burton, Tara Isabella. "White Evangelicals Are The Only Religious Group To Support Trump." Vox. October 3, 2018. Accessed February 13, 2020. https://www.vox.com/identities/2018/10/3/17929696/white-evangelicals-prri-polltrump-presidency-support

Callahan, Leslie D. "The Black Church in Trump's America: Refuge and Resistance.” Mississippi Link 23:6 (December 1, 2016): 10. 
Campbell, Heidi A., Katherine Arredondo, Katie Dundas, and Cody Wolf. "The Dissonance of 'Civil' Religion in Religious-Political Memetic Discourse During the 2016 Presidential Elections." Social Media and Society (April-June 2018): 115 .

CBN News. "Franklin Graham on Islam, Immigration, P. Parenthood." Filmed [October 2015]. YouTube video, 6:33. Posted [October 2015]. https://www.youtube.com/watch?v=sb32FrYqPRA [accessed March 5, 2020].

. "It's Disgraceful:' Franklin Graham Rebukes Immigration Policy on CBN Drawing National Attention.” Filmed [June 2018]. YouTube video, 0:50. Posted [June 2018]. https://www.youtube.com/watch?v=bmpX11JONrI

CBS News. "Hillary Clinton Says Half of Trump's Supporters Are in a "Basket of Deplorables." Filmed [September 2016]. YouTube video, 2:12. Posted [September 2016]. https://www.youtube.com/watch?v=PCHJVE9trSM

. "Why Evangelical Christians Still Support President Trump Despite Controversies". Filmed [March 2018]. YouTube video, 9:58. Posted [March 2018]. https://www.youtube.com/watch?v=miROBFtuEYE

CNN. "Albert Mohler Discusses Trump and Evangelicals on CNN Tonight," Filmed (October 2016]. YouTube video, 8:05. Posted [October 2016]. https://www.youtube.com/watch?v=exvuCgWiIGk

. "Falwell Jr. on Trump: We're Not Electing a Pastor-in Chief." Filmed [June 2016]. YouTube video, 9:45. Posted [June 2016]. https://www.youtube.com/watch?v=G42VEGGmliQ

. "Jerry Falwell Jr.: Evangelicals Forgive Trump". Filmed [January 2018]. YouTube video, 5:19. Posted [January 2018]. https://www.youtube.com/watch?v=vzJ6Ou8ZUKs

. "Trump Mocks Reporter with Disability.” Filmed [November 2015]. YouTube video, 0:45. Posted [November 2015). https://www.youtube.com/watch?v=PX9reO3QnUA

Cober-Lake, Justin. "Why Are Evangelicals So Full of Fear? And So Supportive of Trump? Interview with Historian John Fea." PopMatters (June 27, 2018): 1-13.

Copeland, C. C. (2009). God-Talk in the Age of Obama: Theology and Religious Political Engagement. Denver University Law Review 86 (2009): 663-669. 
Corbett, Michael, Julia Corbett-Hemeyer, and Matthew J. Wilson. Politics and Religion in the United States. New York: Routledge Publishing, 2014.

Cox, Daniel, E.J. Dionne, William A. Galston and Robert P. Jones, "Report: What It Means to Be an American: Attitudes in an Increasingly Diverse America Ten Years after 9/11.” Brookings. September 6, 2011. Accessed April 14, 2020. https://www.brookings.edu/research/what-it-means-to-be-an-american-attitudesin-an-increasingly-diverse-america-ten-years-after-911/

Crouch, Andy. "Speak Truth to Trump." Christianity Today. October 10, 2016. Accessed March 24, 2020.

http://www.christianitytoday.com/ct/channel/utilities/print.html?type=article\&id= 136354

C-Span. "Donald Trump Remarks in Orlando, Florida." Filmed [August 2016]. CSpan video, 46:04. [Posted August 2016]. https://www.c-span.org/video/?4138771/donald-trump-addresses-evangelicalleaders-orlando-florida.

. "Liberty University Commencement Address." Filmed [May 2017]. C-Span video, 58:57. https://www.c-span.org/video/?428429-1/president-trump-deliversliberty-universitycommencement-address\&live.

. "Presidential Candidate Donald Trump at Liberty University." Filmed [January 2016]. C-Span video, 50:00. Posted [January 2016]. https://www.cspan.org/video/?403331-1/donald-trump-remarksliberty-university.

. "Presidential Candidate Donald Trump Remarks in Detroit." Filmed

(September 2016]. C-span video, 14:30. Posted [September 2016]. https://www.cspan.org/video/?414743-1/donald-trump-speaksafricanamerican-church-detroit.

. "Trump Makes Fun of Communion." Filmed [July 2015]. YouTube video, 0:49. Posted [July 2015]. https://www.youtube.com/watch?v=7sWzJZMTNd4

De La Torre, Miguel A., ed. Faith and Resistance in the Age of Trump. Maryknoll, NY: Orbis Books, 2017.

Denker, Angela. Red State Christians: Understanding the Voters Who Elected Donald Trump. Minneapolis, MN: Augsburg Fortress Publishers, 2019.

Dionne, E. J. Why Americans Hate Politics. New York: Simon \& Schuster, 2004.

Djupe, Paul and Ryan L. Claassen, eds. The Evangelical Crackup?: The Future of the Evangelical-Republican Coalition. Philadelphia, PA: Temple University Press, 2018. 
Dobson, James. "Breaking the Bonds of Welfare-Part 1 with Dr. James Dobson's Family Talk," Dr. James Dobson's Family Talk. Filmed [March 2019]. YouTube video, 25:59. Posted [March 2019].

https://www.youtube.com/watch?v=u9GRFLg18Ec

. "Dr. Dobson's July Newsletter." Dr. James Dobson's Family Talk. July 2019. Accessed March 5, 2020.

https://www.drjamesdobson.org/news/commentaries/archives/2019newsletters/july-newsletter-2019

. "Dr. James Dobson: How Christians Can Support Donald Trump but Condemn Bill Clinton.” Charisma News. October 12, 2016. Accessed February 12, 2020. http://www.charismanews.com/politics/opinion/60502-dr-jamesdobson-how-christians-can-support-donald-trump-but-condemn-bill-clinton

. "Support Letter" (September 1998). Ontology. September 1998. Accessed February 22, 2020, http://ontology.buffalo.edu/smith/clinton/character.html

Dreher, Rod. "The Benedict Option: By Embracing Their Minority Status, Christians Can Revive Their Faith." Spectator 333: 9842 (April 15, 2017): 12-13.

. The Benedict Option. New York: Sentinel Publishers. 2017.

Dudley, J. Broken Words: The Abuse of Science and Faith in American Politics. New York: Crown Publishers, 2011.

Edgell, Penny. "An Agenda for Research on American Religion in Light of the 2016 Election.” Sociology of Religion 78:1 (2017): 1-8.

Eerdmans Publishing. "Interview with John Fea, Author of BELIEVE ME." Filmed [June 2018]. YouTube video, 30:20. Posted [June 2018]. https://www.youtube.com/watch?v=uagHfIvezqE

Ehley, Brianna. "Trump Rolls Back Obamacare Birth Control Mandate." Politico. October, 6, 2017. Accessed February 24, 2020.

https://www.politico.com/story/2017/10/06/trump-rolls-back-obamacarescontraception-rule-243537

Emerson, Michael, and Christian Smith. Divided by Faith: Evangelical Religion and the Problem of Race in America. Oxford University Press, 2000. 
Erickson, Erick. "Erick Erickson: Here's What I Decided After Pastors Begged Me to Reconsider My NeverTrump Stance." Washington Post. September 23, 2016. Accessed February 27, 2020. https://www.washingtonpost.com/news/acts-offaith/wp/2016/09/23/heres-what-i-decided-after-several-pastors-begged-me-toreconsider-my-nevertrump-stance

Evans, Michael S. "Religion and Political Decision Making." Journal for the Scientific Study of Religion 53:1 (March 2014): 145-163.

Evans, Rachel Held. "Donald Trump and a Tale of Two Gospels." Rachel Held Evans Blog. January 28, 2016. Accessed February 27, 2020. https://rachelheldevans.com/blog/donald-trump-gospel-liberty

Falwell, Jerry. “A True Memorial Day.” Sermon Central.” September 17, 2000. Accessed March 2, 2020. https://www.sermoncentral.com/sermons/a-true-memorial-dayjerry-falwell-sermon-on-principles-139230

. "Jerry Falwell Jr., President of Liberty University, Speaks at the Republican National Convention July 21, 2016" Filmed [July 2016]. YouTube video, 7:01. Posted [July 2016]. https://www.youtube.com/watch?v=5YcOz2J7vuE

. Twitter Post. September 28, 2018. https://twitter.com/JerryFalwellJr/status/1045853333007798272?ref_src=twsrc\%5 Etfw\%7Ctwcamp\%5Etweetembed\%7Ctwterm\%5E1045853333007798272\&ref url=https\%3A\%2F\%2Fthehill.com\%2Fblogs\%2Fblog-briefing-room\%2F40915 jerry-falwell-jr-conservatives-and-christians-need-to-stop-electing

Fea, John. Believe Me: The Evangelical Road to Donald Trump. Grand Rapids, MI: Eerdmans Publishing, 2018.

. "Evangelical Fear Elected Trump." The Atlantic. June 24, 2018. Accessed February 13, 2020. https://www.theatlantic.com/ideas/archive/2018/06/a-historyof-evangelical-fear/563558/ 2011

FitzGerald, Frances. The Evangelicals: The Struggle to Shape America. New York: Simon \& Schuster, 2017.

Fox Business. "America Needs Merit-based Immigration System: Pastor Jeffress." Filmed [January 2018]. YouTube video, 4:07. Posted [January 2018]. https://www.youtube.com/watch?v=JbxoNOR3u_Y 
. "Why Religion Doesn't Play a Factor in Trump's Immigration Order." Filmed [February 2017]. YouTube video, 2:44. Posted [February 2017]. https://www.youtube.com/watch?v=5eO58kabN98.

Fox News. “Jerry Falwell Jr. on Evangelicals' Role in Trump's Election.” Filmed [December 2016]. YouTube video, 10:48. Posted [December 2016]. https://www.youtube.com/watch?v=jzAzeTCcrtQ

Fox News. “Jerry Falwell Jr. on President Trump's Commencement Speech.” Filmed [May 2017]. YouTube video, 7:01. Posted [May 2017]. https://www.youtube.com/watch?v=K7d3ZjwHRrc

Fowler, Robert Booth, Allen D. Hertzke and Laura R. Olson. Religion and Politics in America: Faith, Culture, and Strategic Choices. NY, NY: Routledge, 2019.

Gerson, Michael. "Evangelical Christians Are Selling Out Faith for Politics." Washington Post. June 23, 2016. Accessed February 27, 2020.

https://www.washingtonpost.com/opinions/evangelical-christians-are-selling-outfaith-for-politics/2016/06/23/f03368de--3964-11e6-8f7cd4c723a2becb_story.html?utm_term=.e6ed9e0999ee

. "Evangelicals Must Not Bear the Mark of Trump." Washington Post. June 2, 2016. Accessed February 25, 2020.

https://www.washingtonpost.com/opinions/evangelicals-may-carry-the-mark-oftrump/2016/06/02/dc0f59b4-28eb-11e6-ae4a-3cdd5fe74204_story.html?utm_term=.f0f6f982fb65.

. "The Temptation: A Prominent Evangelical Writer Explains How His Movement Lost Its Way and Fell Hard for Trump." The Atlantic. April 2018. Accessed February 27, 2020.

https://www.theatlantic.com/magazine/archive/2018/04/the-lasttemptation/554066/

. "Trump and the Evangelical Temptation." The Atlantic. April 4, 2018. Accessed February 18, 2020.

https://www.theatlantic.com/magazine/archive/2018/04/the-lasttemptation/554066/

Goldberg, Michelle. Kingdom Coming: The Rise of Christian Nationalism. New York: W.W. Norton, 2006.

Gordon Conwell University. "Randall Balmer, Mark Massa, and John Fea-Politics and Evangelicals". Filmed [April 2019]. YouTube video, 41:38. Posted [May 2019]. https://www.youtube.com/watch?v=jgHvJZ3FRfM 
Gorski, Philip. American Covenant: A History of Civil Religion from the Puritans to the Present. Princeton, NJ: Princeton University Press, 2017.

."Why Evangelicals Voted for Trump: A Critical Cultural Sociology." American Journal of Cultural Sociology 5:3 (July 31, 2017): 338-354.

Grace Cathedral, San Francisco. "The Forum with Jim Wallis: Christ in Crisis". Filmed [November 2019]. YouTube video, 104:12. Posted [November 2019]. https://www.youtube.com/watch?v=eMjCYRgkKDI

Graham, Franklin. Facebook Post. July 15, 2015. https://www.facebook.com/FranklinGraham/posts/967305353325646 [accessed March 5, 2020].

Greeley, A.M., and M. Hout. The Truth About Conservative Christians: What They Think and What They Believe. Chicago: University of Chicago Press, 2006.

Green, Emma. "The Tiny Blond Bible Teacher Taking on the Evangelical Political Machine." The Atlantic. October 2018. Accessed February 27, 2020. https://www.theatlantic.com/magazine/archive/2018/10/beth-moore-biblestudy $/ 568288 /$

. "Trump is Surrounding Himself with Evangelical Pastors." The Atlantic. June 21, 2016. Accessed February 18, 2020. https://amp.theatlantic.com/amp/article/488114/

Green, John C. The Faith Factor: How Religion Influences American Elections. Westport, CT: Praeger, 2007.

, Mark J. Rozell, and Clyde Wilcox, eds. The Christian Right in American Politics: Marching to the Millennium. Washington, DC: Georgetown University Press, 2003.

Green Mountain Academy. "Brian McLaren: Being Church in the Trump Era (Part 2)." Filmed [February 2017]. YouTube video, 51:41. Posted [February 2017]. https://www.youtube.com/watch?v=OnKXnFqCHsk

. "GMALL Lectures - Understanding Evangelicalism and the Religious Right." Filmed [May 2016]. YouTube video, 51:41. Posted [June 2016]. https://www.youtube.com/watch?v=-6rXkR6WYng 
Grudem, Wayne. "Why Voting for Donald Trump is a Morally Good Choice" (Part 1). The Christian Post. July 28, 2016. Accessed March 24, 2020. https:/townhall.com/columnists/waynegrudem/2016/07/28/why-voting-fordonald-trump-is-a-morally-good-choicen2199564

Grzymala-Busse, Anna. "Why Comparative Politics Should Take Religion (More) Seriously.” Annual Review of Political Science 15 (2012): 421-442.

Gushee, David. "Why the Christian Right Still Supports Trump." Religion News Service. October 15, 2016. Accessed February 27, 2020. http://religionnews.com/2016/10/15/christian-right-still-trump/

Guttman, Nathan. "Evangelicals Hail Trump's Policy Moves." Forward. February 17, 2017. 3-5 (3). Accessed from ProQuest, February 27, 2020.

Hallowell, Billy. "'Our Nation Is in Trouble': Franklin Graham Warns That 'We've Turned Our Back on God' - but He Has a Bold Plan to Fight Back." The Blaze. December 31, 2015. Accessed March 2, 2020. https://www.theblaze.com/news/2015/12/31/our-nation-is-in-trouble-franklingraham-warns-that-weve-turned-our-back-on-god-but-he-has-a-bold-plan-tofight-back

Harvard Divinity School. "The End of White Christian America: A Conversation with E. J. Dionne and Robert P. Jones." Filmed [February 2018]. YouTube video, 144:49. Posted [February 22, 2018]. https://www.youtube.com/watch?v=gRqTYX6IwAY

Haselby, Sam. The Origins of American Religious Nationalism. New York: Oxford University Press, 2015.

Hirschl, Ran and Ayelet Shachar. "Competing Orders? The Challenge of Religion to Modern Constitutionalism." The University of Chicago Law Review 85:2 (March 2018): 425-456.

Howe, Ben. The Immoral Majority: Why Evangelicals Chose Political Power Over Christian Values. New York: Harper Collins, 2019.

IRCPL. "Religion and the Elections." Filmed [October 2016]. YouTube video, 1:44:09. Posted [October 24, 2016]. https://www.youtube.com/watch?v=0dPC3GVPNio

ITV News. "Donald Trump Vows to Ban Muslims Entering US." Filmed [December 2015]. YouTube, 0:30. Posted [December 2015]. https://www.youtube.com/watch?v=viDffWUjcBA 
Jeffress, Robert. "Dr. Robert Jeffress Responds to San Bernardino Terrorist Attacks." Pathway to Victory. N.D. Dr. Robert Jeffress Pathway to Victory. Accessed March 2, 2020. https://ptv.org/dr-robert-jeffress-san-bernardino-terrorist-attacks/

. "Why Trump is Triumphant with Evangelicals ... For Now." Fox News. September 8, 2015. Accessed February 18, 2020.

https://www.foxnews.com/opinion/why-trump-is-triumphant-with-evangelicalsfor-now

JFK Library. "Religion and Politics in America." Filmed [November 2018]. YouTube video, 132:40. Posted [November 29, 2018]. https://www.youtube.com/watch?v=gzHais2xWnc

Johnson, R. Evangelicals at an Impasse. Louisville: John Knox Press, 1979.

Johnson, Stephen D., and Joseph B. Tamney. "The Christian Right and the 1984 Presidential Election.” Review of Religious Research 27 (1985): 124-33.

Jones, Robert. "Donald Trump and the Transformation of White Evangelicals." Time. November 19, 2016. Accessed March 24, 2020. https://time.com/4577752/donaldtrump-transformation-white-evangelicals/ . The End of White Christian America. New York: Simon \& Schuster. 2016.

Justice, Jessilyn and Taylor Berglund. "Trump, Palin Challenge ORU Students to Launch 'Great Awakening."” Charisma News. January 20, 2016. Accessed February 22, 2020. https://www.charismanews.com/politics/54595-trump-palinchallenge-oru-students-to-launch-great-awakening.

Labberton, Mark, ed. Still Evangelical: Insiders Reconsider Political, Social, and Theological Meaning. Downers Grove, IL: Intervarsity Press, 2018.

Keller, Timothy. "Can Evangelicalism Survive Donald Trump and Roy Moore." The New Yorker. December 19, 2017. Accessed February 27, 2020. https://www.newyorker.com/news/news-desk/can-evangelicalism-survive-donaldtrump-and-roy-moore

Kellstedt, P., \& Smidt, C. 1972. Evangelicals in the Post-Reagan Era. Journal for the Scientific Study of Religion 31 (1972): 330-338.

Keneally, Meghan. "List of Trump's Accusers and Their Allegations of Sexual Misconduct." ABC News. June 25, 2019. Accessed February 25, 2020. https://abcnews.go.com/Politics/list-trumps-accusers-allegations-sexualmisconduct/story? $\mathrm{id}=51956410$ 
Kohut, A., Green, J. C., Keeter, S., \& Toth, R. C. The Diminishing Divide: Religion's Changing Role in American Politics. Washington, DC: Brookings Institute, 2000.

Kruse, K. One Nation Under God: How Corporate America Invented Christian America. New York: Basic Books, 2016.

Kurien, Prema. "Who Speaks for Indian Americans? Religion, Ethnicity, and Political Formation." American Quarterly 59:3 (September 2007): 759-783.

Kuruvilla, Carol. “Here's How Franklin Graham Justifies Trump's Expected Refugee Ban.” Huffington Post. January 25, 2017. Accessed March 5, 2020. https://www.huffpost.com/entry/frankling-grahamrefugees_n_5889049ce4b061cf898c6c42

. "Researchers Discover Common Thread Among Christians Who Voted For Trump." Huffington Post. April 4, 2018. Accessed February 13, 2020. https://www.huffpost.com/entry/researchers-discover-common-thread-betweenevangelicals-who-voted-for-trump_n_5abbd15ae4b04a59a313c5ea

Labberton, Mark, ed. Still Evangelical?: Insiders Reconsider Political, Social, and Theological Meaning. Downers Grove, IL: Intervarsity Press, 2018.

Lambert, Frank. Religion in American Politics: A Short History. Princeton, NJ: Princeton University Press, 2008.

Lichtman, A.J. White Protestant Nation: The Rise of the American Conservative Movement. New York: Grove Press, 2009.

Liebman, Robert and Robert Wuthnow. The New Christian Right. New York: Aldine Publishing Company, 1983.

Life Today. "James Robison: National Affairs Briefing." Filmed [August 1980]. YouTube video, 25:57. Posted [March 13, 2014]. https://www.americanrhetoric.com/speeches/ronaldreaganreligiousliberty.htm

Lifeway Groups Ministry. "What does the Bible say about Religious Liberty? feat. Russell Moore." Filmed [February 2017]. YouTube video, 1:38. Posted [February 2017]. https://www.youtube.com/watch?v=EjZ8z-trL2k

Lindsay, D. M. Faith in the Halls of Power: How Evangelicals Joined the American Elite. Oxford: Oxford University Press, 2007. 
Lewis, Matt. "Matt Lewis Interviews Ben Howe". Filmed [August 2019]. YouTube video, 53:48. Posted [August 2019].

https://www.youtube.com/watch?v=ZfgatySGxmk

Lucas, Fred. "Fact Check: Does Trump Have the Most Successful Judicial Nomination Record Since George Washington?” The Daily Signal. July 26, 2019. Accessed March 3, 2020. https://www.dailysignal.com/2019/07/26/fact-check-does-trumphave-the-most-successful-judicial-nomination-record-since-george-washington/

Luther, Martin. "Against the Robbing, Murdering Hordes of Peasants," 1525. Quoted in, E. G. Rupp and Benjamin Drewery, Martin Luther, Documents of Modern History. London: Edward Arnold, 1970 (121-126).

Maccaskill, Nolan. "Trump's Favorite Bible Verse: 'Eye for an Eye.' Politico. April 4, 2016. Accessed February 27, 2020. https://www.politico.com/blogs/2016-gopprimary-live-updates-and-results/2016/04/trump-favorite-bible-verse-221954

Mansfield, Stephen. Choosing Donald Trump: God, Anger, Hope, and Why Christian Conservatives Supported Him. Grand Rapids, MI: Baker, 2017.

Manza, Jeff and Clem Brooks. "The Religious Factor in U.S. Presidential Elections, 1960-1992." American Journal of Sociology 103:1 (July 1997): 38-81.

Marsden, George M. Fundamentalism and American Culture: The Shaping of the Twentieth-Century Evangelicals, 1870-1925. New York: Oxford University Press, 1980.

. Religion and American Culture: A Brief History. Grand Rapids, MI: Eerdmans Publishing, 2018.

Marshall, Peter, and David Manuel. The Light and Glory: Did God Have a Plan for America? Old Tappan, NJ: Power Books, 1977.

Marti, Gerardo. "The Unexpected Orthodoxy of Donald J. Trump: White Evangelical Support for the $45^{\text {th }}$ President of the United States." Sociology of Religion: A Quarterly Review 80:1 (2019): 1-8.

Martinez, Jessica, and Gregory Smith. "How the Faithful Voted: A Preliminary 2016 Analysis." Pew Research Center. November 19, 2016. Accessed March 10, 2020. https://www.pewresearch.org/fact-tank/2016/11/09/how-the-faithful-voted-apreliminary-2016-analysis/

Martin, William. With God on Our Side: The Rise of the Religious Right in America. New York: Broadway Books. 1996. 
McDaniel, E. L., \& Ellington, C. G. "God's Party? Race, Religion, and Partisanship over Time.” Political Research Quarterly 61 (2008): 180-191.

, I. Nooruddin, and A.F. Shortle. God's Nation: Religious Nationalism in Contemporary American Politics. Chicago: Midwest Political Science Association, 2009.

Medhurst, Martin J. "Mitt Romney, 'Faith in America,' and the Dance of Religion and Politics in American Culture." Rhetoric \& Public Affairs 12:2 (2009): 195-222.

. "The Religious Rhetoric of Anti-Trump Evangelicals in the 2016 Presidential Election.” Res Rhetorica (February 2017): 1-14.

Merritt, Jonathan. "Defining 'Evangelical."” The Atlantic. December 7, 2015. Accessed February 13, 2020. https://www.theatlantic.com/politics/archive/2015/12/evangelicalchristian/418236/

Miller, Daniel D. “The Mystery of Evangelical Trump Support.” Constellations 26 (2019). 43-58.

Miller, Eric C., ed. The Rhetoric of Religious Freedom in the United States. Lanham, MD: Lexington Books, 2018.

Mohler, R. Albert Jr., "Donald Trump Has Created an Excruciating Moment for Evangelicals." Washington Post. October 9, 2016. Accessed March 25, 2020. https://www.washingtonpost.com/news/acts-of-faith/wp/2016/10/09/donaldtrump-has-created-an-excruciating-moment-forevangelicals/?utm_term $=.64 \mathrm{cbebcc}$.

Monk-Turner, E. "White Evangelical Activism and the Gender Divide in the 2016 Presidential Election.” Society 57 (2020): 30-40.

Moore, Russel. “A White Church No More.” New York Times. May 6, 2016. Accessed February 27, 2020. https://www.nytimes.com/2016/05/06/opinion/a-whitechurch-no-more.html?ref=opinion\&_r $=1$

. "Black, White, and Red All Over: Why Racial Justice is a Gospel Issue." Southern Seminary Magazine (Summer 2012): 40-41.

. "Crucifying Jim Crow: Conservative Christianity and the Quest for Racial Justice.” Southern Baptist Journal of Theology 8 (Summer 2004): 4-23. 
. "From the House of Jacob to the Iowa Caucuses: The Future of Israel in Contemporary Evangelical Political Ethics." Southern Baptist Journal of Theology 11 (Winter 2007): 4-19.

. "Is Donald Trump Right About Closing the Border to Muslims?"

Russellmoore.com, December 7, 2015. Accessed March 25, 2020.

http:www.russellmoore.com/2015/12/07/is-donald-trump-right-about-closing-theborder-to-muslims/

. "The Gospel According to Jane Roe: Abortion Rights and the Reshaping of Evangelical Theology." Southern Baptist Journal of Theology 7 (Summer 2003): 40-53.

. "The Kingdom of God in the Social Ethics of Carl F. H. Henry: A TwentyFirst Century Reappraisal." Journal of The Evangelical Theological Society 55:2 (2012): 77-98.

MSNBC. "Donald Trump: 'I Would Certainly Implement' Database For Muslims." Filmed [November 2015]. YouTube video, 1:23. Posted [November 2015]. https://www.youtube.com/watch?v=8Q4SDWMnjak

Myers, William R. "Following Trump: Are Evangelicals Willing Participants in a 'New' Religion?” Theology Today 76:2 (2019): 103-113.

N. A. "A Declaration by American Evangelicals Concerning Donald Trump." Change.org. September 29, 2016. Accessed February 27, 2020. https://www.change.org/p/donald-trump-a-declaration-by-american-evangelicalsconcerning-donald-trump

. "Backing Trump, White Evangelicals Flip Flop on Importance of Candidate Character.” PRRI. October 19, 2016. Accessed February 28, 2020.

https://www.prri.org/research/prri-brookings-oct-19-poll-politics-election-clintondouble-digit-lead-trump/

. "Franklin Graham: Trump 'Defends the Faith'." Filmed [November 2018]. Axios on HBO video, 48. Posted [November 2018]. https://www.axios.com/franklin-graham-donald-trump-6b18159f-d481-48e29eb3-ea48f4eb26aa.html.

. "President Trump's Pro-life Wins." Susan B. Anthony List. N.D. Accessed March 5, 2020. https://www.sba-list.org/trump-pro-life-wins 
. "Religious Landscape Study," Pew Research Center. N.D.

https://www.pewforum.org/religious-landscape-study (accessed February 13, 2020).

. The Ethics \& Religious Liberty Commission. "Protecting the Future of Religious Higher Education." The Ethics \& Religious Liberty Commission of the Southern Baptist Convention. August 9, 2016. Accessed March 10, 2020. https://erlc.ocm/resource-library/statements/protecting-the-future-of-religioushigher-education

."The Man Who Mobilized the Evangelical Vote. Filmed [April 2018].

YouTube video, 10:18. Posted [April 2018]. https://www.youtube.com/watch?v=BcC53j32BW4

. "Trump Administration Immigration Accomplishments." The Federation for American Immigration Reform. 2020. Accessed March 6, 2020. https://www.fairus.org/issue/presidential-administration/trump-administrationimmigration-accomplishments

NBC. "Meet The Woman Who Many Call President Elect Donald Trump's Spiritual Adviser." Filmed [January 2017]. YouTube video, 2:13. Posted [January 2017]. https://www.youtube.com/watch?v=-3-whDsYvTU

Noll, Mark A., and Luke E. Harlow, eds. Religion and American Politics: From the Colonial Period to the Present. New York: Oxford University Press, 2007. ProQuest Ebook Central, https://ebookcentral-proquestcom.proxy.lib.pdx.edu/lib/psu/detail.action?docID $=415713$

Noll, Mark A. The Rise of Evangelicalism: The Age of Edwards, Whitefield and the Wesleys. Downers Grove, IL: InterVarsity Press, 2003.

Ottosson, Bjorn. "Religious Voters Impact on Midterm Elections Georgetown Panel." Filmed [November 2018]. YouTube video, 147:52. Posted [November 20, 2018]. https://www.youtube.com/watch?v=ivlq7FHIK74

Pengelly, Martin. “Trump Predicts Demographics Make 2016 'Last Election Republicans Can Win." The Guardian. September 9, 2016. Accessed February 27, 2020. https://www.theguardian.com/us-news/2016/sep/09/trumpdemographics-2016-election-republicans-can-win.

Pew Research Center. "How Americans See Illegal Immigration, the Border Wall and Political Compromise." Pew Research Center. January 16, 2019. Accessed March 5, 2020. https://www.pewresearch.org/fact-tank/2019/01/16/how-americans-seeillegal-immigration-the-border-wall-and-political-compromise/ 
Prager, Dennis. "Dennis Prager Interviews Ben Howe". Filmed [August 2019]. YouTube video, 29:18. Posted [August 2019].

https://www.youtube.com/watch?v=WOEF8mv_yG8

Religion and Ethics Newsweekly. "Russell Moore on Donald Trump's Anti-Muslim Rhetoric." Filmed [December 2015]. YouTube video, 1:16. Posted [December 2015]. https://www.youtube.com/watch? $v=4$ Lppmnq4d5w

Retro Report. “The Roots of Evangelicals' Political Fervor.”. Filmed [October 2018]. YouTube video, 11:15. Posted [October 2018]. https://www.youtube.com/watch? $\mathrm{v}=\mathrm{nAzPVhn}-\mathrm{drU} \& \mathrm{t}=122 \mathrm{~s}$

Robbins, Jeffrey W., and Clayton Crocket. Doing Theology in the Age of Trump: A Critical Report on Christian Nationalism. Eugene, OR: Cascade Books, 2018.

Rozell, Mark J., and Clyde Wilcox, eds. God at the Grassroots, 2016: The Christian Right in American Politics. Lanham, MD: Rowman \& Littlefield, 2018.

Schat, David. The Myth of American Religious Freedom. New York: Oxford University Press, 2011.

Scott, Eugene. "Trump Believes in God, but Hasn't Sought Forgiveness." CNN Politics, July 18, 2015. Accessed February 27, 2020. https://www.cnn.com/2015/07/18/politics/trumphas-never-soughtforgiveness/index.html

Scott, Rodney. Twitter Post. November 4, 2019, 4:52 AM. https://twitter.com/USBPChief/status/1191337312363438080

Secular Talk. "Pat Robertson Rips Immigrants_Like Jesus.” Filmed (February, 2015]. YouTube video, 8:26. Posted [February 2015]. https://www.youtube.com/watch?v=fAO5b7ITtHo

Senate Finance Committee. "Minority Staff Review of Without Walls International Church Paula White Ministries." Senate.gov. 2011. Accessed March 2, 2020. https://www.finance.senate.gov/imo/media/doc/WWIC\%20Whites\%2001-0511.pdf

Smith, C. Christian America?: What Evangelicals Really Want. Berkeley: University of California Press, 2000. 
Smith, Samuel. "7 Accomplishments That Evangelicals Like." The Christian Post. December 15, 2017. Accessed February 24, 2020.

https://www.christianpost.com/news/7-trump-accomplishments-evangelicalslike.html?page $=3$

Soumala, Karla. "Immigrants and Evangelicals: What Does the Bible Say?" Crosscurrents (September 2017): 590-599.

Strang, Stephen E. God and Donald Trump. Chicago: Frontline Books, 2017.

Straughn, Jeremy Brooke, and Scott L. Feld. "America as a 'Christian Nation?' Understanding Religious Boundaries of National Identity in the United States." Sociology of Religion 71 (2010:: 280-306.

Taylor, Justin. "Is Segregation Scriptural? A Radio Address from Bob Jones on Easter of 1960.” The Gospel Coalition. July 26, 2016. Accessed February 27, 2020. https://www.thegospelcoalition.org/blogs/evangelical-history/is-segregationscriptural-a-radio-address-from-bob-jones-on-easter-of-1960/

The 700 Club. "Recognizing God's Hand in Donald Trump's Election". Filmed [November 2017]. YouTube video, 12:33. Posted [November 2017]. https://www.youtube.com/watch?v=aRcnJPQqY0c

The Arizona Center for Judaic Studies. "Religion and the 2016 Election: Historical Context and Unusual Alliances - Prof. Randall Balmer". Filmed [February 2017]. YouTube video, 36:36. Posted [March 2017]. https://www.youtube.com/watch?v=PjMhdHHkDT0

The Gospel Coalition. "Russell Moore on Whether America Is a Christian Nation." Filmed [July 2017]. YouTube video, 3:31. Posted [July 2017]. https://www.youtube.com/watch?v=MxVMltj_yd0

. "Russell Moore on Why Christians Should Fight for the Religious Liberties of False Religions." Filmed [December 2016]. YouTube video, 2:33. Posted [December 2016]. https://www.youtube.com/watch?v=W3DuAJ24kIY

The Mike Gallagher Show. "Dr. @RobertJeffress and @Peter Wehner Join Mike for an Important Debate over Evangelical Christian Support of Trump." The Mike Gallagher Show, July 12, 2016. https://www.mikeonline.com/dr-robertjeffresspeter_wehner-join-mike-for-an-important-debate-over-evangelical-christianssupport-of-trump/ 
Theobald, Bill. "Why Hush Money Michael Cohen Paid Stormy Daniels Was an Illegal Campaign Donation." USA Today. December 14, 2018. Accessed February 25, 2020. https://www.usatoday.com/story/news/2018/12/14/michael-cohenexplaining-why-hush-money-illegal-donation/2287647002/

The Presbyterian Lay Committee. "Declaration Concerning Religion, Ethics, and the Crisis in the Clinton presidency." The Presbyterian Lay Committee. November 16, 1998. Accessed February 22, 2020. https://layman.org/news86fd/

The White House. "President Trump Delivers Remarks at the Israeli American Council National Summit 2019." Filmed [December 2020]. YouTube video, 58:46. Posted [December 2020]. https://www.youtube.com/watch? $\mathrm{v}=7$ YlonD037SQ\&t=1652s

Troodler, N Aaron. "Jews Should Cast Their Votes with Religion in Mind." Jewish Exponent 232 (September 20, 2012): 26.

Utter, G., True, J.: Conservative Christians and Political Participation - A Reference Handbook. ABC Clio, Santa Barbara, California, 2004.

Wallis, James, America's Original Sin: Racism, White Privilege, and the Bridge to a New America. Grand Rapids, MI: Brazos Press, 2017.

. “Christians Called to Resist Trump's Bigotry.” Huffing Post. April 29, 2016. Accessed February 27, 2020. https://www.huffpost.com/entry/christians-called-toresi_b_9809222

. “Donald Trump: Narcissist in Chief." Sojourners. July 9, 2015, Accessed Marcy 5, 2020. https://sojo.net/print/216430.

. God's Politics: Why the Right Gets It Wrong and the Left Doesn't Get It. New York: Harper Collins Publishing, 2006.

. Living God's Politics: A Guide to Putting Your Faith into Action. San Francisco: New York: HarperOne, 2006.

. The Great Awakening: Reviving Faith and Politics in a Post-Religious Right America. New Haven, CT: Yale University Press, 2008.

. The Soul of Politics: Beyond 'Religious Right' and 'Secular Left'. Tampa, FL: Mariner Publishing, 1994.

Wallnau, Lance. God's Chaos Candidate. Keller, TX: Killer Sheep Media. 2016. 
. "Why I Believe Trump Is the Prophesied President." Charisma News.

October 5, 2016. Accessed February 28, 2020.

https://www.charismanews.com/politics/opinion/60378-why-i-believe-trump-isthe-prophesied-president

Wehner, Peter. "The Theology of Donald Trump." Ethics and Policy Center. N.D. Accessed February 27, 2020. https://eppc.org/publications/the-theology-ofdonald-trump/

. "Why I Will Never Vote for Donald Trump." Ethics and Policy center. N.D. Accessed February 27, 2020. https://eppc.org/publications/why-i-will-never-votefor-donald-trump/

Weiland, Noah. "Evangelicals, Having Backed Trump, Find White House Front Door Open." Philadelphia Tribune, March 30, 2018.

Whitehead Andrew and Samuel L. Perry. "Make America Christian Again: Christian Nationalism and Voting for Donald Trump in the 2016 Presidential Election." Sociology of Religion: A Quarterly Review. 29:2 (2018): 147-171.

. Taking America Back for God: Christian Nationalism in the United States. New York: Oxford University Press, 2020.

Williams, Daniel K. "Jerry Falwell's Sunbelt Politics: The Regional Origins of the Moral Majority." Journal of Policy History 22:2 (April 2010): 12547.

Wisdom, Alan. "Immigration: A Brief Analysis.” The Aquila Report. January 16, 2012. Accessed February 25, 2020. https://www.theaquilareport.com/immigration-abrief-analysis/

Women in the World. "Hillary Clinton's Keynote Address at the 2015 Women in the World Summit." Filmed [April 2015]. YouTube video, 23:11. Posted [April 2015]. https://www.youtube.com/watch?v=pVTiAJ1e9SM

Woodward, Kenneth. "How Religion Got Trump: Faith in 2016 Election." Commonweal (May 18, 2018): 18-21.

Wong, Janell, S. Immigrants, Evangelicals and Politics in an Era of Demographic Change. New York: Russell Sage Foundation, 2018.

Young, Josiah Ulysses. "Making America Great Again? An Essay on The Weightier Matters of The Law: Justice and Mercy and Faith." Black Theology 16:1 (2018): 53-60. 